UNIVERSIDADE DE SÃO PAULO

FACULDADE DE FILOSOFIA, CIÊNCIAS E LETRAS DE RIBEIRÃO PRETO DEPARTAMENTO DE PSICOLOGIA E EDUCAÇÃO PROGRAMA DE PÓS-GRADUAÇÃO EM PSICOBIOLOGIA

\title{
Comportamento Social de machos e fêmeas castrados do gato doméstico (Felis catus L.) em confinamento.
}

Ana Paula Ferreira de Oliveira

Dissertação apresentada à Faculdade de Filosofia, Ciências e Letras de Ribeirão Preto - USP, como parte das exigências para obtenção do título de Mestre em Ciências, Área: Psicobiologia.

Ribeirão Preto 
UNIVERSIDADE DE SÃO PAULO

FACULDADE DE FILOSOFIA, CIÊNCIAS E LETRAS DE RIBEIRÃO PRETO DEPARTAMENTO DE PSICOLOGIA E EDUCAÇÃO PROGRAMA DE PÓS-GRADUAÇÃO EM PSICOBIOLOGIA

\title{
Comportamento Social de machos e fêmeas castrados do gato doméstico (Felis catus L.) em confinamento.
}

\author{
Ana Paula Ferreira de Oliveira
}

\begin{abstract}
Dissertação apresentada à Faculdade de Filosofia, Ciências e Letras de Ribeirão Preto-USP, como parte das exigências para obtenção do título de Mestre em Ciências, Área: Psicobiologia.
\end{abstract}

Orientador: Wagner Ferreira dos Santos

Ribeirão Preto 
Oliveira, Ana Paula Ferreira

Comportamento Social de machos e fêmeas castrados do gato doméstico (Felis catus L.) em confinamento. Ribeirão Preto, 2002.

116 p. : il. ; $30 \mathrm{~cm}$

Dissertação de Mestrado, apresentada à Faculdade de Filosofia, Ciências e Letras de Ribeirão Preto/USP - Área de concentração: Psicobiologia.

Orientador: Santos, Wagner Ferreira.

1. Gato doméstico. 2. Comportamento social. 3. Castração. 
Esta dissertação é dedicada a todos aqueles que me ajudaram direta ou indiretamente para a realização da mesma, inclusive aos gatos, sem os quais este trabalho não seria feito e minha vida não teria graça. 


\section{AGRADECIMENTOS}

Ao meu orientador Prof. Dr. Wagner Ferreira dos Santos, pela confiança e liberdade na orientação.

Ao Prof. Dr. Carlos Camargo Alberts pela valiosa e indispensável colaboração e ajuda no nível de uma orientação.

Ao Prof. Dr. Fernando Frei pela indispensável e importante ajuda na análise estatística.

Aos proprietários do gatil, Senhor José Arthur e Dona Imaculada e todos os seus funcionários principalmente a funcionária Santa.

A minha amiga Flávia Andréia da cidade de Assis pela indispensável e valiosa ajuda quando precisei ir a Assis e pela ajuda no uso dos programas usados neste trabalho.

Aos meus familiares por todo o apoio, tão importantes para a minha inteira formação.

A todos os meus amigos, principalmente, João Lúcio e Regiane pelas conversas e reflexões, que tanto escutaram minhas questões, queixas e reclamações.

Ao amigo e namorado Hélio Victor por ir a Assis comigo quando precisei.

Ao Programa de Pós-graduação da Psicobiologia e a sua secretária Renata Beatriz Vicentini por sempre me atualizar sobre datas e prazos.

Ao CNPq pela bolsa concedida.

A todos os gatos do gatil, sem os quais o estudo não seria feito. 


\section{ÍNDICE}

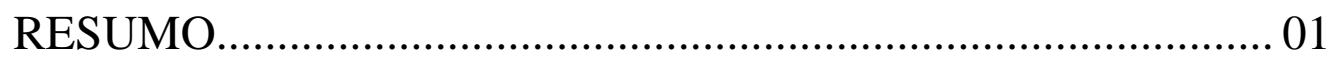

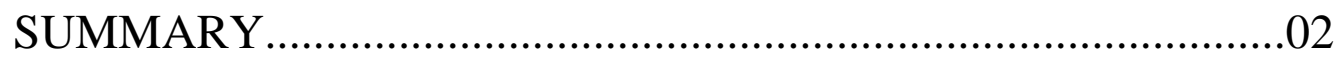

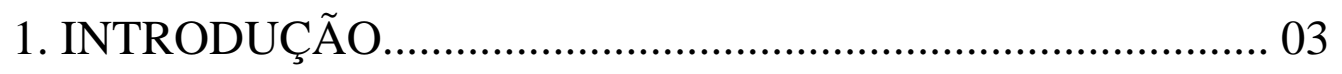

1.1 Origem do gato doméstico........................................................... 03

1.2 Domesticação............................................................................ 04

1.3 Relação com o homem................................................................ 06

1.4 Por que estudar gatos?..............................................................07

1.5 Flexibilidade de estilos de vida................................................... 08

1.6 Sistema Social............................................................................ 09

1.7 Gatos Castrados..........................................................................

1.8 Dimorfismo Sexual................................................................. 13

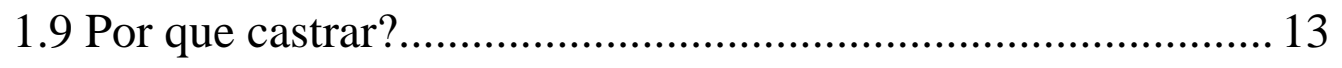

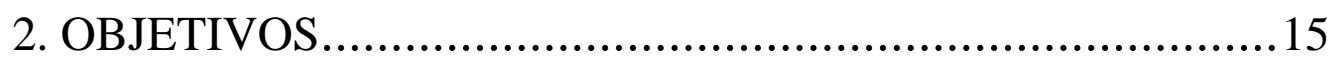

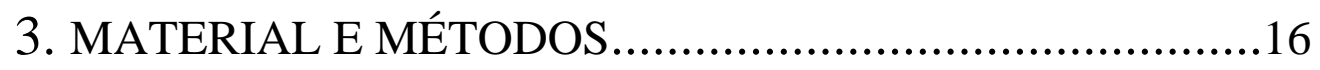

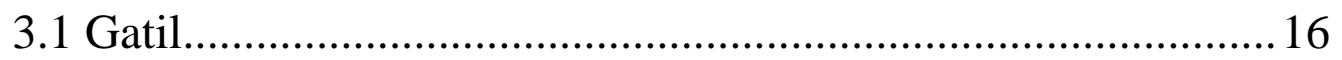

3.1.1 Lista dos Locais......................................................................17

3.2 Animais............................................................................ 17

3.2.1 Lista dos animais...................................................................19

3.3 Categorias comportamentais..................................................... 22

3.3.1 Lista de abreviações e descrição Categorias Sociais..............22

3.3.2 Lista de abreviações e descrição Categorias não Sociais......25

3.4 Observações comportamentais...................................................26

3.5 Análises Comportamentais........................................................27

3.5.1 Análise da Freqüência comportamental..................................27

3.5.2 Análise da Seqüência comportamental...................................29 
4. RESULTADOS......................................................................

4.1 Freqüência comportamental......................................................... 30

4.1.1 Teste Estatístico das categorias Sociais.................................. 30

4.1.2 Teste Estatístico das categorias não Sociais..............................37

4.1.3 Teste Estatístico dos Locais................................................... 43

4.2 Sequiência comportamental........................................................ 46

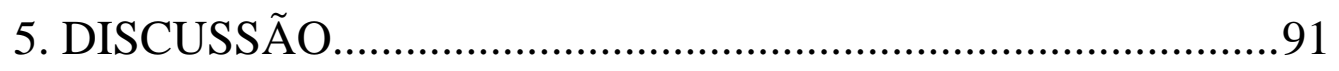

5.1 Freqüência Comportamental.................................................... 91

5.1.1 Categorias comportamentais Sociais.......................................91

5.1.2 Categorias comportamentais não Sociais................................94

5.1.3 Locais............................................................................. 96

5.1.4 Individualidade.......................................................................97

5.2 Seqüência Comportamental...................................................... 98

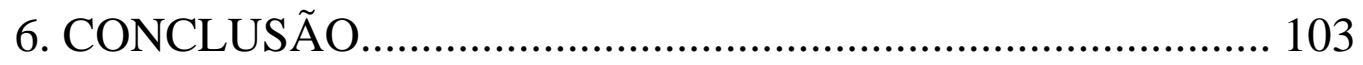

7. REFERÊNCIAS BIBLIOGRÁFICAS.......................................104

8. ANEXOS........................................................................... 


\section{RESUMO}

Oliveira, A. P. F. Comportamento Social de machos e fêmeas castrados do gato doméstico (Felis catus L.) em confinamento. 2002. 116 p. Dissertação Mestrado - Faculdade de Filosofia, Ciências e Letras de Ribeirão Preto, Universidade de São Paulo, Ribeirão Preto.

O gato doméstico (Felis catus L.) exibe uma grande flexibilidade em seu comportamento social e no seu estilo de vida. Isto é devido a vários fatores, entre eles, disponibilidade de alimento e refúgio, mudanças ambientais, interação com o homem, composição dos grupos, características genéticas e a castração. Os animais machos e fêmeas não castrados e de vida livre exibem um repertório comportamental distinto, os machos tendem a ter uma vida mais solitária vagando por amplas extensões territoriais, enquanto que as fêmeas exibem uma vida mais gregária. $\mathrm{O}$ objetivo deste trabalho foi examinar o comportamento social de gatos domésticos castrados, machos e fêmeas, em confinamento com a intenção de se verificar os efeitos da castração no comportamento e se o repertório comportamental de ambos é sexualmente dimórfico, através das análises de freqüência e seqüência das categorias comportamentais. Foram levantadas 18 categorias comportamentais sociais e 12 categorias não sociais e foi observado o comportamento de 40 gatos domésticos machos ( $\mathrm{n}=18)$ e fêmeas $(\mathrm{n}=22)$ num ambiente confinado (gatil) com área total de 19,2 metros quadrados, durante um período de 11 meses totalizando 160 horas de observação. Cada animal foi observado durante 15 minutos em cada sessão de observação, utilizando-se o método de amostra focal do comportamento. A análise de freqüência das categorias comportamentais sociais e não socais foram feitas através do teste estatístico não paramétrico de Mann-Whitney com nível de 5\% de significância $(\mathrm{p}=0,05)$. Os resultados do teste não mostraram diferenças significativas entre os grupos de machos e fêmeas, indicando, assim, existir influência da castração nos comportamentos de ambos os grupos, ainda que preservando a individualidade dos animais. Contudo a análise seqüencial do comportamento mostrou uma mínima diferença entre os machos e fêmeas castrados mesmo na ausência da regulação hormonal do comportamento. Portanto conclui-se que parte do comportamento dos gatos não sofre influência hormonal e que o método de análise seqüencial do comportamento é refinado o suficiente para mostrar características comportamentais que não foram mostradas pela análise de freqüência.

Palavras-chave: gato doméstico, comportamento social, castração. 


\section{SUMMARY}

Oliveira, A. P. F. Social behavior of neutered domestic cat (Felis catus L.) in confinement. 2002. 116 p. Dissertation - Faculdade de Filosofia, Ciências e Letras de Ribeirão Preto, Universidade de São Paulo, Ribeirão Preto.

The domestic cat (Felis catus L.) exhibits a great flexibility in its social behavior and lifestyle. This can be due to several factors, among them, food and refuge availability, environmental changes, interaction with humans, group composition, genetic characteristics and castration. Literature states that non neutered male and female animals of free life exhibit distinct behavioral repertoires. Males tend to have a more solitary life moving throughout wide territorial extensions, while females exhibit a more gregarious life. The aim of this work was to examine the social behavior of castrated domestic cats, males and females, in confinement, to verify the effects of neutering on the behavioral repertoire, through the frequency and sequence analyses of behavior. 18 social and 12 non social behavioral categories were selected. 40 domestic cats, males $(n=18)$ and females $(n=22)$, were observed in a indoor confined context with 19,2 square meters in area, for a period of 11 months and 160 hours of observation. Each animal was observed for 15 minutes in each observation session, being used the focal sample method. Statistical analysis for the frequency of each behavioral category, done using the non parametric test of Mann-Whitney with $5 \%(p=0,05)$ of significance, didn't show any significant gender difference, suggesting that castration change natural behavior, possibly because of a probable absence of sexual hormones. Sequential analysis, however, did show subtle gender

differences, possibly raised by different environmental -- i.e. 'cultural' -- influences in both male and female cats.

Keywords: domestic cat, social behavior, castration. 


\section{INTRODUÇÃO}

\subsection{Origem do gato doméstico}

Uma das teorias sobre a origem do gato doméstico atual afirma que ele é descendente primário do gato selvagem da África e do sudoeste da Ásia, Felis silvestris lybica (Bateson e Turner, 1988). No entanto sua classificação sistemática é ainda um tanto controversa. Kerby apud Serpell (1988) tem agrupado o gato selvagem europeu e o gato selvagem africano como uma única espécie, Felis silvestris. Embora o gato doméstico Felis silvestris catus seja provavelmente descendente da subespécie africana Felis silvestris lybica, existe a discussão da possibilidade de hibridização entre o gato doméstico e o gato selvagem europeu Felis silvestris silvestris, e gatos da floresta Felis chaus (Serpell, 1988). Esta origem imprecisa é também baseada na morfologia de seu esqueleto, pois o gato doméstico difere relativamente pouco de seus parentes selvagens. Em muitas das suas raças modernas, seu crânio tende a ser mais largo e a região facial mais curta do que muitas espécies selvagens. Mas estas características são altamente variáveis e incertas quanto ao meio de distinguir entre a morfologia de gatos domésticos e selvagens.

Ainda, a sua origem é em geral baseada mais em evidência a partir de relatos do que em evidência osteológica (Zeuner apud Serpell, 1988).

A combinação dos fatores, formas híbridas do gato doméstico com seus parentes selvagens com uma certa resistência genética à modificação extrema ao longo do tempo (quando comparado com os cães por exemplo, pois só recentemente os gatos têm mostrado alguma modificação específica), moldaram uma divergência 
morfológica em relação às formas ancestrais (Todd e Clutton - Brock apud Serpell, 1988).

A evidência comportamental também dá suporte à idéia de que a subespécie $F$. s. lybica como o mais próximo ancestral do gato doméstico (Serpell, 1988). Contudo os híbridos entre gatos selvagens europeus e os gatos domésticos também tendem a ter uma semelhança em comportamento. Embora variedades do gato europeu F. s. silvestris não sejam totalmente indomáveis, sua domesticação poderia ter se perdido ao longo do tempo. Já a subespécie africana, F. s. lybica, mostra um temperamento dócil e adaptação a habitats urbanos, como o que ocorre no gato doméstico atual (Serpell, 1988).

Apesar de todas estas evidências em relação aos prováveis ancestrais do gato doméstico, talvez ainda não sejam suficientes para se conhecer com certeza a sua verdadeira origem.

\subsection{Domesticação}

Provavelmente, a domesticação ocorreu no Egito Antigo ou em suas proximidades (Serpell, 1988) há aproximadamente 5000 a 6000 anos e sua introdução na Europa começou há aproximadamente 2000 anos (Grzimek e Kingdon apud Walker, 1991). Fragmentos de ossos e dentes da região de Jericó identificados como pertencentes a Felis silvestris lybica datam de 6000 - 7000 a.C. No entanto não há evidência osteológica que estes animais foram domesticados e provavelmente eles representam restos de gatos selvagens mortos (Clutton - Brock apud Serpell, 1988).

O início do processo de domesticação se deu, provavelmente, devido a Civilização Egípcia, na qual a economia era baseada no cultivo e armazenamento de grãos. A abundância de estoques de grãos armazenados pelos agricultores em áreas 
urbanas atraiu roedores para as cidades egípcias. Atraídos pelos roedores, os gatos selvagens locais aproximaram-se dos humanos e suas residências, templos e vilas. No início eram apenas tolerados ao redor dos depósitos e das casas. Após este período, os egípcios reconheceram os gatos como verdadeiros controladores de pestes. Em seguida os gatos foram admitidos até dentro das moradias e desenvolveram uma associação permanente com os humanos (Zeuner; Mersent e Serpell apud Serpell, 1988).

Fora do Egito, na Grécia, Palestina e outras regiões da Antiguidade os gatos eram conhecidos, mas eram relativamente incomuns porque os egípcios não permitiam que eles fossem tirados de seu próprio país. Isto sustenta a crença de que o Egito é o centro de sua origem (Robinson, 1971).

No final, a domesticação teve até uma função religiosa (Grzimek e Kingdon apud Walker, 1991). Em 1600 a.C. o gato foi claramente domesticado, declarado e cultuado como objeto sagrado, religioso e ligado a divindades (Robinson, 1971; Walker, 1991). Sendo que maus tratos a ele podiam levar a morte (Serpell, 1988).

Através dos tempos, o surgimento do Cristianismo causou ao gato a perda de sua posição sagrada, pois na Idade Média o gato foi declarado, por manifestações da Igreja Católica, como representação do mal, associado com bruxaria, sofrendo então, uma onda de perseguição (Hofmann, 1997; Serpell, 1988).

Até os dias de hoje o gato ainda é visto como símbolo às vezes do bem e às vezes do mal, com uma relação de amor e ódio de acordo com as necessidades humanas, suas superstições e suas diferentes culturas. No entanto nos últimos 50 100 anos, os gatos tem alcançado uma imagem mais positiva e vem sendo considerado o principal animal de companhia (Serpell, 1988). 


\subsection{Relação com o Homem}

Durante a história de vida do gato e sua relação com o homem, não houve evidência de que a sua domesticação foi propositalmente planejada pelo homem (a não ser muito recentemente), como ocorreu com os outros animais domésticos (bovinos, suínos, ovinos, caprinos e mesmo cães) (Leyhausen, 1988), pois o gato não oferecia um serviço direto ao homem (Leyhausen, 1965; Alberts, 1996). De acordo com Leyhausen (1988) o gato “aproveitou” a oportunidade oferecida pelo homem e foi capaz de desenvolver e adotar uma diversidade de socialização na conquista desta nova condição. Leyhausen apud Karsh e Turner (1988) afirma que os gatos foram domesticados por eles mesmos, o que comprova a teoria de autodomesticação.

Muitas pessoas mostram antipatia por gatos. Isto pode ser devido ao fato de eles serem relativamente independentes e que por isso não podem ser tão facilmente treinados ou controlados como o que ocorre com os cães e outros animais domésticos (Karsh e Turner, 1988). De acordo com Leyhausen (1965) os gatos são capazes de desenvolver diferentes personalidades e temperamento e podem também adotar diversos estilos de vida, como animais de companhia, gatos de fazenda ou ainda viverem totalmente livres (gatos ferais) (Karsh e Turner, 1988).

Atualmente o número de casas com gatos nos EUA tem aumentado rapidamente e recentemente tem superado o número de casas com cães. Além disso, os gatos são muito usados como animais de companhia e usados também para auxiliar terapias humanas (Karsh e Turner, 1988).

Os gatos são animais domésticos muito populares também na Europa (Bradshaw e Cook, 1996; Heidenberger, 1997). Eles muitas vezes vivem dentro das casas de 
seus proprietários e assim são capazes de se ajustar ao estilo de vida de seus donos (Heidenberger, 1997).

\subsection{Por que estudar gatos?}

O gato é um animal muito apreciado pelo homem e relativamente bem conhecido na cultura popular. Certamente este animal, mais do que qualquer outra espécie, despertou muitos sentimentos no homem, e por conta disso foi tanto perseguido quanto apreciado (Turner e Bateson, 1988) em vários países e culturas.

Grandes quantias de dinheiro são gastas com animais domésticos e a indústria de produção de ração e produtos afins para animais domésticos tornou-se um importante negócio (Beck apud Mertens e Schar, 1988). Ao mesmo tempo as condições de vida humana estão cada vez mais ligadas à progressiva urbanização. Isto talvez seja uma das razões sobre porque os animais domésticos, especialmente os gatos, se tornaram uma presença importante na vida do homem. Com isso, os animais domésticos acabaram mantidos sob várias condições, as quais algumas vezes diferindo grandemente dos seus ambientes naturais ou seminaturais. E, cada vez mais, os gatos estão sendo mantidos em ambientes fechados, confinados em casas ou apartamentos com pouco ou nenhum acesso ao ambiente externo. Tal espaço limitado pode resultar em problemas físicos e distúrbios comportamentais (Mertens e Schar, 1988).

O tédio ou falta de atividades é uma das maiores causas de estresse físico e comportamental em gatos confinados, de ambos os sexos. Os problemas mais comuns se referem à ansiedade, problemas alimentares, agressão, urina imprópria (necessidades biológicas feitas no interior da residência de seus proprietários), entre outros (Heidenberger, 1997; van den Bos, 1998). E cada vez mais ênfase é colocada na reprodução seletiva dos gatos para formas extremas como ocorreu com os cães, por exemplo, já que estes animais foram domesticados milhares de anos depois do 
cão. É esperado com isso um aumento do número de problemas dentro da relação homem - gato (Mertens e Schar, 1988).

Em geral os médicos veterinários em clínicas são geralmente mais qualificados para responderem problemas de saúde e clínica médica, do que sobre o conhecimento científico do comportamento natural do gato. Isto se aplica também ao conhecimento das condições ambientais de vida aceitáveis, além daquilo que os humanos esperam de seus gatos e quais são as habilidades que satisfazem essas expectativas. Tal conhecimento precisa ser produzido para satisfazer uma boa relação do gato com o

homem (Mertens e Schar, 1988). É esperado então que proprietários de gatos e etólogos só ganharão com o aumento do entendimento de seu comportamento (Bateson e Turner, 1988).

\subsection{Flexibilidade de estilos de vida}

Entretanto, os gatos são animais adaptáveis e modificam seu comportamento sensivelmente a mudanças ambientais (Martin e Bateson, 1988). Kerby e Macdonald (1988) afirmam que o sistema social e espacial de gatos apresenta uma grande variação, pois estes animais vivem em habitats diversos desde ilhas sub-antárticas até cidades industriais e as diferentes densidades podem variar desde 1 até mais de 2000 indivíduos por quilômetro quadrado (Langeveld e Niewold ; Isawa, Doi e Ono apud Kerby e Macdonald, 1988). Além disso, as variações do sistema social ocorrem nas diferenças de composição dos grupos, pois dentro das populações a variação social se dá no comportamento de machos, fêmeas, adultos e jovens.

Portanto a variação do comportamento social dentro da espécie é comum e ela ocorre devido a mudanças na ecologia alimentar, padrões reprodutivos (van Aarde apud Kerby e Macdonald, 1988) constituições genéticas, características individuais, 
diferenças nas experiências dos indivíduos (Todd e O’brien apud Kerby e Macdonald, 1988), interação do animal com o homem e fatores ambientais como disponibilidade de refúgio e alimento (Voith e Borchelt, 1996; Lindell et al, 1997).

Algumas das variações vistas no gato doméstico podem ser também produto de seleção artificial, pois a domesticação de animais parece levar a altos níveis de variabilidade quando estes são comparados com as formas não domesticadas (Burt e Bell apud Bateson e Turner, 1988).

\subsection{Sistema Social}

Durante muitos anos considerou-se a noção equivocada de que os gatos são animais solitários e não apresentam qualquer tipo de organização social (Leyhausen, 1988). Por este mesmo motivo investigações sobre a socialidade dos gatos foram negligenciadas (de Boer, 1977; Natoli e De Vito, 1991). Esta mesma atitude foi reforçada principalmente pela freqüente afirmação de que o leão seria o único felino social (Packer e Pusey, 1983; Natoli e De Vito, 1991). Entretanto, mesmo gatos solitários que gastam a maior parte do tempo sozinhos, são vistos ocasionalmente na companhia de outros gatos. A maioria de tais ocasiões envolve um adulto, presumivelmente a mãe e filhotes, subadultos ou jovens (Kerby e Macdonald, 1988), no entanto a mãe na companhia de seus filhotes não pode ser considerada uma definição de comportamento social, pois animais não sociais também apresentam esta característica. No trabalho atual usou-se a definição de grupo social pela distribuição de muitos animais num espaço limitado (gatil) com disponibilidade ilimitada de recursos (alimento).

Estes mesmos autores, Kerby e Macdonald (1988), a partir de seus estudos e da revisão de vários outros, afirmam que uma unidade social é fundamental para a 
organização de todas as populações de gatos, além de observarem que animais de vida social interagem com seus conspecíficos e que gatos que vivem em colônias passam a metade de seu tempo dormindo com o corpo em contato com outros gatos.

Leyhausen (1988) afirma que o ancestral selvagem do gato, embora tenha habitado da Ásia menor ao sul da África exceto os habitats de deserto extremo, ele nunca encontrou uma enorme diversidade de condições ecológicas como o que ocorreu com populações de gatos ferais. Pois o gato doméstico e/ou feral habitou regiões extremas em relação ao seu ancestral selvagem, desde a Austrália a áreas industriais da Inglaterra, da região rural da Suécia a Galápagos, do Japão a ruínas de Roma.

No entanto Leyhausen (1988) afirma que não se conhece a organização social do ancestral selvagem do gato, mas sabem-se em quais regiões ele viveu, (Ásia menor ao sul da África exceto os locais de deserto extremo). De acordo com este raciocínio pode-se considerar que o gato doméstico mostra uma diversidade social maior que seus ancestrais selvagens (Leyhausen, 1988), em relação apenas aos locais habitados por ambas espécies.

Contudo, a afirmação do parágrafo anterior não significa necessariamente que os gatos possuam um maior potencial social em relação ao seu ancestral selvagem, até porque não há dados suficientes da organização social do mesmo (Leyhausen, 1988).

Por outro lado, estudos recentes mostram que a condição social do gato doméstico, alcançando um nível similar ao do leão, não somente se confirma, como indicam que a socialidade entre os felinos não é uma exceção, mas uma tendência geral na Familia Felidae (Alberts, 2002).

Interações entre gatos de uma mesma colônia se dão por uma variedade de formas incluindo, aproximações, toques, comportamento de limpeza social, vocalizações (Bradshaw e Cook, 1996), comportamento de corte, cópulas, lutas e 
play (neste trabalho play é definido como qualquer tipo de brincadeira, individual ou não). A freqüência relativa desses tipos de interação parece depender da natureza do animal tanto quanto das características do local no qual o gato vive (Mertens, 1991; Bradshaw e Cook, 1996) e da relação entre os animais.

Em muitas espécies sociais as relações entre os pares de indivíduos são assimétricas. Um indivíduo consistentemente suplantará o outro quando competirem por algum recurso valorizado, tal como alimento, refúgio ou locais de descanso e acasalamento. O arranjo de indivíduos dominantes e subordinados no grupo é denominado de hierarquia de dominância (Martin e Bateson, 1986).

De acordo com Dards (1983), Kerby e Macdonald (1988), Liberg e Sandell (1988), a organização social e espacial de gatos ferais e/ou domésticos é estruturada numa forma hierárquica linear de dominância a qual é formada por machos dominantes que seriam os machos reprodutores (Kerby e Macdonald, 1988; Leyhausen, 1988) e machos subordinados.

Liberg e Sandell (1988) revisaram estudos de densidades populacionais e organização espacial de gatos domésticos, e afirmam que o padrão espacial de fêmeas é determinado pela abundância e dispersão de alimento, enquanto que a organização espacial do macho é determinada pela distribuição de fêmeas receptivas pelo menos no período de acasalamento. Observaram também que os machos reprodutores têm territórios até quatro vezes maiores que os dos machos subordinados e a razão para isso seria que os machos subordinados migram extensivamente a procura de fêmeas.

Os machos tendem a ter uma vida mais solitária, vagando entre vários grupos de fêmeas e seus territórios são maiores e sobrepõem o território de grupos de fêmeas (Kerby e Macdonald, 1988; Turner e Bateson, 1988).

Mertens e Schar (1988) observaram diferenças territoriais de machos e fêmeas. O território dos machos pode variar de 0,4 a 990 hectares, enquanto que o das fêmeas 
entre 0,02 a 170 hectares. Tais territórios incluem locais de alimento e descanso, as fêmeas especificamente passam maior parte de seu tempo (81\%) dentro do seu território (Mertens e Schar, 1988).

Liberg e Sandell (1988) e Macdonald et al (1987) concluíram que em geral as populações de gatos podem ser divididas naquelas em que as fêmeas formam grupos e naquelas onde não formam (Kerby e Macdonald, 1988). As fêmeas são territoriais em um caso e mutuamente tolerantes e cooperativas em outros, mantendo relações amigáveis e de afiliação entre as fêmeas não aparentadas e as aparentadas. Elas podem ou não tolerar machos dominantes dentro de seus territórios, podem ter vida solitária ou viver num círculo social compartilhando moradia, recursos e cuidando e criando filhotes num tipo de parceria (Leyhausen, 1988).

O comportamento e organização sociais de gatos tem sido estudados em muitas partes do mundo (Leyhausen, 1988) sendo que a estrutura da população e o padrão espacial são características que definem o sistema social (Natoli e De Vito, 1991). No entanto, apesar da existência de muitos trabalhos sobre a organização social e espacial de colônias de gatos, há informação limitada a respeito da organização social de gatos castrados e sobre os efeitos comportamentais da castração no gato doméstico. Alguns trabalhos de gatos castrados enfocam a interação homem-animal, comportamento alimentar (Bradshaw e Cook, 1996), alguns sobre agressividade (Lindell et al, 1997) e problemas comportamentais relatados pelos proprietários dos animais (Heidenberger, 1997; Horwitz, 1997) e comportamentos de caça e play sem dar enfoque à organização social (Hall e Bradshaw, 1998). Portanto este trabalho vem preencher uma lacuna existente nos trabalhos de comportamento social de gatos domésticos. 


\subsection{Gatos castrados}

Alguns fatores são particularmente de grande valor na pesquisa das diferenças comportamentais entre animais, idade, sexo, reprodução, personalidade, experiência, aprendizagem e a castração (Mertens e Schar, 1988). Esta última tem uma grande influência na modificação da vida dos gatos, uma vez que pode afetar os seus comportamentos espacial, social (Mertens e Schar, 1988) e sexual (Hart e Eckstein, 1997).

\subsection{Dimorfismo Sexual}

Em geral o conceito de desenvolvimento sociosexual de quase todas as espécies de mamíferos inclusive de gatos, é baseado num aumento repentino de secreção de testosterona no macho. Este aumento age no cérebro trazendo mudanças citoarquiteturais sexuais específicas no hipotálamo e outras áreas do cérebro que são relacionadas a displays de comportamento sexual típico de machos (Arnold e Gorski, 1984; Hart e Eckstein, 1997). As áreas hipotalâmicas do cérebro das fêmeas são estrutralmente organizadas numa direção feminina devido à falta de testosterona. No desenvolvimento, o fenótipo da fêmea é formado primeiro, e através da ação de andrógenos o fenótipo macho é formado a partir do padrão fêmea que já existe (Hart e Eckstein, 1997).

\subsection{Por que castrar?}

Como a castração altera e controla o comportamento de animais de companhia (Hart e Eckstein, 1997), há algumas razões para se castrar um animal doméstico: como a regulação da população de gatos de vida livre ou confinados (Mertens e Schar, 1988) e a eliminação de comportamentos desagradáveis, como brigas, 
comportamento de vagar e borrifos de urina, mostrados principalmente por machos adultos. No entanto nem todos os machos apresentam uma mudança comportamental após a castração. Há diferenças individuais entre animais em relação a castração. Em vista disso, há a necessidade de pesquisas adicionais para o entendimento (incluindo o comportamental) das diferenças individuais entre as espécies causadas pelos efeitos da castração (Hart e Eckstein, 1997). 


\section{OBJETIVOS}

Os gatos dos estudos citados anteriormente são animais não castrados e de vida livre, já neste atual trabalho os gatos estudados são castrados e confinados, assim sendo deseja-se examinar se o comportamento social de gatos domésticos castrados em confinamento é sexualmente dimórfico, além de verificar os efeitos da castração em seu comportamento. Em colônias de animais castrados os comportamentos social e espacial devem se dar por outra forma que não seja a determinada sexualmente.

Em vista do que foi exposto o presente trabalho, objetiva estudar o comportamento de gatos domésticos castrados em confinamento através das análises da freqüência e seqüência comportamental dos grupos de machos e fêmeas. 


\section{MATERIAL E MÉTODOS}

\subsection{Gatil}

O estudo foi executado no município de Ribeirão Preto no gatil situado aos fundos de uma quadra esportiva localizada na rotatória Amim Calil. As observações ocorreram no período de julho de 2001 a junho de 2002 totalizando 160 horas de observação, sempre no período da manhã.

O gatil situa-se numa área coberta de frente ao córrego Ribeirão Preto. Possui uma área de 19.2 metros quadrados inteiramente fechado por grades, inclusive o teto (veja anexo 1), com dois ambientes direito e esquerdo com passagem entre ambos através de uma porta, ambos limitados por uma mureta lateral de um metro de altura. No interior dos dois ambientes do gatil há um banco de cimento com uma altura de $50 \mathrm{~cm}$. Logo acima e no nível da grade há uma tábua de madeira onde a maioria dos animais permanecem e nas laterais dos dois ambientes do gatil há cadeiras e cestas suspensas. O gatil é higienizado diariamente por uma funcionária. Preso às grades da mureta frontal do gatil há o comedouro onde os animais se alimentam com ração seca e no solo há tigelas de água.

O gatil foi dividido em quadrantes (locais) com o objetivo de descobrir se há locais preferenciais para animais de cada sexo. Ambos os ambientes do gatil, esquerdo e direito, foi dividido em seis locais gerais (tábua, muretas laterais, banco de cimento, solo, cestas suspensas e cadeiras), sendo que os locais, tábua, muretas laterais e solo foram subdivididos (veja lista dos locais).

A planta do gatil está no anexo 1. 


\subsubsection{Gatil: lista dos locais}

- Tábua (T)

(1: lado direito, 2: meio, 3: lado esquerdo, co:comedouro, Td: tábua direita e Te: tábua esquerda)

1. Gatil direito ( $\mathrm{Td} 1, \mathrm{Td} 2, \mathrm{Td} 3, \mathrm{coD})$

2. Gatil esquerdo (Te1, Te2, Te3, coE)

- Muretas Laterais direita (MLd) e esquerda (MLe)

1. Gatil direito (d) (MLdd, MLed)

2. Gatil esquerdo (e) (MLde, MLee)

- Banco de cimento

1. Gatil direito

2. Gatil esquerdo

- Solo (S)

(S1: solo, S2: porta lat. direita do G. D., S3: porta meio, S4: porta lat. esquerda do G. E., S5: potes de água )

1. Gatil direito (d) (Sd1, Sd2, Sd3, Sd5)

2. Gatil esquerdo (e) (Se1, Se3, Se4, Se5)

- Cestas suspensas

1. Gatil direito

2. Gatil esquerdo

- Cadeiras

1. Gatil direito

2. Gatil esquerdo

\subsection{Animais}

A população total de gatos na área do estudo e imediações é composta por aproximadamente 80 indivíduos, entre jovens e adultos, machos e fêmeas, todos castrados. Sendo que deste total aproximadamente entre 45 e 55 vivem dentro do 
gatil. Os animais passam a noite presos e são soltos no período da manhã até as 12:00 horas no máximo para então ficarem livres durante o dia e então serem presos novamente as 18:00 horas aproximadamente. Portanto ficam a maior parte de um período de 24 horas presos dentro do gatil.

Os dados analisados no atual estudo se referem a 40 animais do total de gatos, 22 fêmeas e 18 machos, sendo que cada um possui 10 sessões de observação.

Os gatos não pertencem a qualquer raça em particular. Por se tratar de gatos que residem num gatil, eles são dependentes da alimentação composta de ração seca e água que ficam a disposição dos animais, que é reposta uma vez ao dia pela proprietária e funcionária.

Por se tratar de muitos animais dentro do gatil, inicialmente no período de julho a novembro de 2001 as observações foram concentradas somente na familiarização, identificação e reconhecimento dos animais, e levantamento das categorias comportamentais, somando assim 50 horas de observação preliminar.

Os animais foram divididos em grupos e sua identificação foi feita de acordo com suas características físicas, através do seu padrão e coloração da pelagem, padrão da cauda e olhos. Mirmovitch (1995) afirma que além destas características, o padrão morfológico sexual de machos e fêmeas (inclusive a região genital) e também o padrão da orelha auxiliam na identificação. Segundo Martin e Bateson (1986) tais características fazem distinguir um indivíduo do outro, contudo a identificação de animais num grande grupo por suas características naturais é difícil e requer tempo, paciência e prática, mas é a melhor maneira para o reconhecimento dos animais, além de não ser um método invasivo como os marcadores externos.

A identificação dos animais foi uma das dificuldades do trabalho. Em alguns grupos foi problemática, principalmente o grupo dos animais pretos e o grupo dos 
rajados de cinza, pois são animais muito semelhantes entre si, ou porque alguns animais não são vistos freqüentemente dentro do gatil.

\subsubsection{Lista dos animais (veja no anexo 3 fotos de alguns indivíduos) Fêmeas}

1. Animal 1.1 - (cinza e branco).

2. Animal 1.6 - (branca menor com olhos amarelos).

3. Animal 1.8 - (branca magra com pintas rajadas de cinza pelo corpo e cauda cinza).

4. Animal 2.1 - (pintada três cores, face triangular).

5. Animal 2.2 - (pintada três cores acinzentada inteira, face achatada, gordinha, olhos amarelos).

6. Animal 2.4 - (pintada três cores acinzentada inteira, magrinha, face triangular, cauda fina).

7. Animal 2.4 - (pintada três cores acinzentada no dorso, face achatada, pescoço e patas branco com pelo curto).

8. Animal 2.5 - (pintada três cores rajada de cinza no dorso com mancha amarela região dorsal pescoço, peito, pescoço e patas posteriores brancas, olhos arregalados, perna curta).

9. Animal 2.6 - (pintada três cores inteira rajada de cinza escuro/preto).

10. Animal 2.7 - (pintada três cores inteira rajada de cinza, magrinha e fina com pelos ralos na parte posterior do corpo).

11. Animal 2.8 - (pintada três cores, peito e pescoço branco, manchas escuras e amarelas num corpo mais claro [Lú]).

12. Animal 3.1 - (preta maior simpática, cauda com pelo curto).

13. Animal 3.3 - (preta menor, cauda peluda). 
14. Animal 3.4 - (preta menor, cauda mais fina e mais comprida, pelo brilhante).

15. Animal 4.1 - (preto e branco escaladora).

16. Animal 4.3 - (preto e branco com região dorsal e metade do rosto (olhos) em preto, pescoço, peito e patas brancas e com a ponta da cauda virada).

17. Animal 4.4 - (preto e branco com pinta preta no lado direito do nariz no queixo, mais peludo, mancha pequena na pata anterior direita, cauda preta, olhos amarelos).

18. Animal 4.7 - (preto e branco com o corpo mais branco e pintas menores pretas, metade da cabeça preta, pinta preta no lado esquerdo do nariz, cauda preta).

19. Animal 4.8 - (branco e preto, dorso e metade da cabeça preta, peito, pescoço e patas brancas, pinta preta no peito branco e no nariz (lado esquerdo) e pinta preta pequena ao lado do olho esquerdo, magro e fino, cauda fina).

20. Animal 6.2.1 - (rajada de cinza, magra, olhos arregalado e esverdeados).

21. Animal 6.2.2 - (rajada de cinza com o pelo em tons de bege, mais peluda, olhos amarelos).

22. Animal 6.3 - (rajada de cinza, peluda [Michele]).

\section{Machos}

1. Animal 1.4 - (branco grande com manchas rajadas de cinza, face triangular).

2. Animal $1.5-$ (caolho).

3. Animal 1.7 - (siamês resfriado).

4. Animal 3.2 - (preto maior simpático, cauda sem pêlo, olho amarelo).

5. Animal 3.7 - (preto grande, quieto, cauda comprida com menos pêlo, meio grisalho, mancha grisalha no peito). 
6. Animal 4.2 - (preto e branco com região dorsal e metade do rosto (olhos) preto, pescoço, peito e patas brancas, mancha escura no queixo e abaixo da boca, cauda curta).

7. Animal 4.5 - (preto e branco com região dorsal e metade do rosto (olhos) preto, pescoço, peito e patas brancas, com pinta preta no lado esquerdo do nariz e face, olho amarelo).

8. Animal 4.6 - (preto e branco com quase toda a face preta, dorso, cabeça e cauda preta e pescoço, peito e patas branca).

9. Animal 5.1 - (bege amarelado, face achatada e olhos azuis).

10. Animal 5.2 - (amarelo com muito pêlo, simpático, pescoço branco, cauda peluda, olhos azuis esverdeados).

11. Animal 5.3 - (bege, face triangular, cauda rajada bege, olhos amarelos esverdeados).

12. Animal 5.5 - (rajado de amarelo mais escuro, olhos azuis).

13. Animal 5.6 - (amarelo com dorso, face, orelhas e cauda amarela, peito e pescoço branco, olhos verdes).

14. Animal 6.1 - (rajado de cinza grande [Quadrado]).

15. Animal 6.5 - (rajado europeu, grande com muito pêlo, dorso preto, olhos esverdeados).

16. Animal 6.6 - (mesclado de cinza escuro magro, dorso preto, olhos esverdeados, cauda mais preta, face grande para um corpo magro e fino).

17. Animal 6.6.1 - (mesclado de cinza e tons de bege, corpo magro e face grande).

18. Animal 6.7 - (mesclado de cinza, olhos grandes e amarelos esverdeados, face triangular). 


\subsection{Categorias comportamentais}

O comportamento consiste de uma seqüência contínua de movimentos e eventos (duração), e antes de ser medido é necessário dividi-lo em unidades ou categorias, as quais devem ser precisamente definidas, sumarizando a informação relevante do comportamento (Martin e Bateson, 1986).

Em relação ao levantamento das categorias comportamentais, as observações preliminares precederam o registro quantitativo do comportamento. Tal observação informal auxiliou no esclarecimento, entendimento e na descrição dos sujeitos e comportamentos. A formulação de uma definição satisfatória de cada categoria comportamental é um processo lento e requer tal período de observação preliminar, além de proporcionar um momento para reflexões sobre as questões e hipóteses do projeto (Martin e Bateson, 1986). Ainda, durante tal processo de “amadurecimento” e mesmo durante o registro do comportamento algumas definições se alteraram, mas de maneira a não prejudicar o registro comportamental, conforme ocorreu a familiaridade com o local e com os animais.

Foram levantadas 18 categorias comportamentais sociais e 12 categorias comportamentais não sociais (veja lista das abreviações e descrições das categorias comportamentais).

\subsubsection{Lista de abreviações e descrição: Categorias Sociais}

1. Aprostoace - Aproximação de algum indivíduo sem tocar mas sendo aceito (ato de caminhar em direção a algum indivíduo e permanecer ao lado ou próximo sem tocar no mesmo). 
2. Aprostoevi - Aproximação de algum indivíduo sem tocar e sendo evitado (ato de caminhar em direção a algum indivíduo sem tocar o outro e não permanecer ao lado ou próximo).

3. Aproctoace - Aproximação de algum indivíduo com o toque e ser aceito (ato de caminhar em direção a algum indivíduo e tocar o outro com o focinho e/ou com o corpo e/ou uma das patas, se esfregando, ou permanecendo encostado, ou sentado ou deitado ou cheirando outro indivíduo permanecendo ao lado ou próximo do mesmo).

4. Aproctoevi - Aproximação de algum indivíduo com o toque e ser evitado (ato de caminhar em direção a algum indivíduo tocando-o com o focinho e/ou com o corpo e/ou uma das patas, se esfregando, encostando, sentando ou deitando ao lado, mas não permanecendo ali).

5. Apr2+indre - Aproximação de 2 ou mais indivíduos e um ou mais destes se retiram (ato de caminhar em direção a mais de 2 indivíduos e permanecer ao lado ou próximo, mas um ou mais desses indivíduos se retiram).

6. Rectoaceit - Receber o toque de outro indivíduo e aceitar (o animal está parado e outro indivíduo se aproxima e o toca com o focinho e/ou com o corpo e/ou uma das patas, e é aceito).

7. Rectoevita - Receber o toque de outro indivíduo e evitar (o animal está parado e outro indivíduo se aproxima e o toca com o focinho e/ou com o corpo e/ou uma das patas, mas afasta-se).

8. Pard1+indi - Parado/acordado encostado em 1 ou mais indivíduos (o animal está sentado ou deitado com o corpo ou parte deste em contato com outros indivíduos). 
9. Paraproace - Parado e ocorre aproximação de outro indivíduo, este é aceito (o animal está sentado ou deitado e outro indivíduo se aproxima e permanece ao seu lado).

10. Paraproevi - Parado e ocorre aproximação de outro indivíduo, este é evitado (o animal está sentado ou deitado e outro indivíduo se aproxima e não permanece ao seu lado).

11. Dormirjunt - Dormindo ou sonolento (olhos cerrados) encostado em um ou mais indivíduos (o animal está deitado dormindo ou sonolento com os olhos cerrados encostado em outros indivíduos).

12. Briga - Brigas (intenção ou ameaça) (comportamento que consiste em aproximação brusca ou mais cautelosa de dois animais com o olhar fixo no oponente, orelhas para trás com ou sem vocalização e levantar e bater ou não com a pata).

13. Defesa - Defesa (o comportamento consiste em afastamento rápido ou retirada do animal com retração do corpo, ou com o corpo encolhido, submissão, fuga).

14. Vocalrosna - Vocalização "rosnar” (dirigida a algum indivíduo numa distância de até um metro).

15. Vocalmiar - Vocalização "miar” (miado ou ronronado dirigido a algum indivíduo numa distância de até um metro).

16. Vocalrecep - Vocalização "receptor” (receber a vocalização/som emitido por qualquer outro indivíduo numa distância de até um metro).

17. Limpezasoc - Limpeza social (comportamento que consiste em lamber ou morder qualquer parte do corpo de outro indivíduo com uma função aparente de limpeza).

18. Autlimpzju - Autolimpeza encostado em 1 ou mais indivíduos (comportamento característico de autolimpeza que consiste em lamber e morder a própria 
pelagem, enquanto o animal está com o corpo em contato com outros indivíduos).

\subsubsection{Lista de abreviações e descrição: Categorias não Sociais}

1. Locomoção - Locomoção (comportamento que se caracteriza pelo ato de caminhar para uma determinada direção).

2. Observação - Observação (comportamento em que o animal está parado e está atento a qualquer evento interno ou externo ao gatil como pessoas, sons, cães, etc.).

3. Dormirsozi - Dormindo (o animal está deitado sozinho dormindo ou sonolento com os olhos cerrados).

4. Paradosozi - Parado/acordado (o animal está parado e acordado sentado ou deitado sozinho).

5. Autlimpzso - Autolimpeza (comportamento característico de autolimpeza que consiste em lamber e morder a pelagem e o animal está sozinho).

6. Vocalinesp - Vocalização inespecífica (vocalização como um miado que não é dirigida a nenhum indivíduo).

7. Vocalmim - Vocalização para humanos (vocalização como um miado dirigida a humanos, inclusive o observador).

8. Play - Play (comportamento de brincadeira como escalar as grades do gatil, morder o ar e/ou levantar a pata tentando pegar mosquitos, etc)

9. Esfregsupf - Esfregar-se e arranhar superfícies e objetos (comportamento caracterizado por esfregar a face e/ou o corpo ou parte desse em superfícies e objetos). 
10. Alimentand - Alimentar-se (comportamento que consiste em alimentar-se de ração seca localizada no comedouro localizado na grade frontal do gatil).

11. Bebendagu - Beber água (comportamento que consiste em beber água nos potes localizados no solo do gatil).

12. Uridefecar - Urinar/Defecar (comportamento que consiste em urinar e/ou defecar no solo do gatil).

\subsection{Observações comportamentais}

Após a identificação dos animais e o levantamento das categorias comportamentais e depois das observações preliminares, a coleta dos dados, (observações comportamentais dos animais) iniciaram-se e ocorreram nos meses de dezembro de 2001 a junho de 2002, e aconteceram sempre no período da manhã, somando 110 horas do registro comportamental, totalizando assim, com as observações preliminares, 160 horas.

Foi usado como método de registro do comportamento, o método escrito, ou seja, tabela (veja anexo 2). O registro escrito do comportamento (anotações, uso de tabelas) é uma poderosa forma de observação, alem de ser barata e flexível. Com a prática e anotações precisas e corretas, uma considerável quantidade de informações podem ser registradas acuradamente (Martin e Bateson, 1986).

Foi elaborada então uma tabela (veja anexo 2) na qual as colunas correspondiam às categorias comportamentais. Foram usados símbolos (letras) que identificavam categorias comportamentais e os (números) as suas respectivas subcategorias. As linhas representavam o momento no qual cada categoria é observada. Além disso, os seguintes registros foram anotados: identidade do animal, data, horário do início da observação, característica do tempo (nublado, temperatura, etc.), localização inicial 
do animal e sessão de observação. Na ocasião de categorias comportamentais ocorrerem juntas, ou quando havia descrição dos movimentos do indivíduo, ou se havia interações entre os indivíduos, ou qualquer outro tipo de informação adicional, era relatado no final da tabela informações adicionais, assim como o momento em que ocorreu.

Cada animal foi observado individualmente num intervalo de 15 minutos, registrando-se continuamente, neste intervalo de tempo, cada categoria comportamental observada; o estado comportamental (local) e o momento no qual ocorreu (evento), e seus dados adicionais anotados na tabela.

O comportamento foi observado usando-se o método de amostra focal do comportamento (Lehner, 1979; Martin e Bateson, 1986). Tal método se caracteriza por registrar todo o comportamento ou várias categorias do comportamento de um indivíduo por uma quantidade de tempo especificada. No entanto tal método limita o número de padrões comportamentais registrados, como a observação dos padrões de outros animais que poderiam ocorrer ao mesmo tempo durante a observação focal, e que poderiam ser registrados e submetidos à análise.

No registro do comportamento social pela amostra focal é necessário registrar também certos aspectos tais como quem iniciou a interação comportamental e para quem ela é dirigida (Lehner, 1979; Martin e Bateson, 1986).

\subsection{Análises Comportamentais}

\subsubsection{Análise da Freqüência Comportamental}

Todos os registros quantitativos das categorias comportamentais e dos estados (locais) observados foram submetidos a um teste estatístico para avaliar diferenças 
em sua freqüência. Tal análise foi feita através do teste não paramétrico de MannWhitney, teste U para amostras independentes (Siegel, 1975). As discussões foram realizadas no nível de $5 \%$ de significância $(\mathrm{p}=0,05)$. Os valores de $\mathrm{p}$ iguais ou menores que 0,05 indicariam diferenças significativas (rejeição da hipótese nula H0) e os valores maiores aceitação de H0.

Os dados referentes a cada animal foram introduzidos no programa Etholog versão 2.2. O programa gerava um relatório de cada sessão de observação (total de 10 para cada animal) que continha as seqüências comportamentais listadas e o local em que o animal se encontrava no momento da observação dentro da área estudada.

Em seguida todos os dados de cada sessão foram introduzidos no programa Excel e foram agrupados numa única sessão para cada animal, para então ser possível introduzi-los no programa Statistica versão 5.5 o qual gerou 2 tabelas para cada animal, uma com a freqüência das categorias comportamentais observadas daquele animal e a outra da freqüência dos locais para aquele animal observado.

Posteriormente estes dados de freqüência de todas as categorias comportamentais e de todos os locais foram agrupados para todas as fêmeas (total 22) e para todos os machos (total 18) (veja tabelas de freqüência 5, 6, 7, 8). Foram então submetidos novamente ao programa Statistica versão 5.5, o qual realizou o teste de Mann-Whitney (veja tabelas 1, 2, 3).

A totalidade dos dados brutos encontra-se depositada em arquivos de microcomputador com cópias em mídias removíveis (disquetes comuns de 1,44 mb ou disquetes de Zip Drive de $100 \mathrm{mb}$ ). 


\subsubsection{Análise da Seqüência Comportamental}

Foi feita a análise da estrutura seqüencial do comportamento usando o método da DiTrees (Direct Trees, ou árvores orientadas), tanto para o grupo dos machos como o grupo das fêmeas, com o objetivo de verificar se houve diferenças na estrutura seqüencial do comportamento de ambos os gêneros.

Este método (DiTrees) consiste em procurar o elemento que provavelmente virá a seguir depois de outro elemento. Ou seja, não se sabe exatamente qual categoria comportamental virá a seguir, mas sabe-se qual é a mais provável, e assim sucessivamente para todas categorias coletadas do comportamento. Assim sendo, partindo-se de uma dada categoria pode-se seguir várias, e a mais provável estará graficamente, mais próxima e a menos provável mais distante, formando assim, com as várias categorias estudadas presentes no diagrama, uma série de ramificações, semelhantes a uma árvore, oferecendo, assim, uma análise gráfica da estrutura seqüencial do comportamento. Cada árvore apresenta uma categoria comportamental como raiz e a partir desta, as prováveis ocorrências de todas as outras categorias (Alberts, 1996). Como são 30 a totalidade das categorias comportamentais, existem 30 árvores orientadas para cada um dos grupos de machos e fêmeas. No entanto foram consideradas e analisadas somente as transições em que a probabilidade de ocorrência comportamental é maior que 0,5\%.

Os relatórios analisados (árvores orientadas) da estrutura seqüencial do comportamento, tanto para o grupo dos machos como o grupo das fêmeas, foram obtidos através do programa PhyloSeq versão 2.1, o qual gerou, inicialmente, as matrizes de transição que são a base para a construção das árvores orientadas. 


\section{RESULTADOS}

Os dados referentes ao teste Mann-Whitney para as categorias comportamentais sociais e não sociais e para os locais estão nas tabelas 1, 2 e 3 respectivamente. Estes dados mostram que não houve diferença significativa entre os sexos tanto para as categorias do comportamento quanto para os locais, apesar de haver diferenças individuais na freqüência das categorias comportamentais.

\subsection{Freqüência Comportamental}

\subsubsection{Teste Estatístico das categorias Sociais}

Os resultados do teste estatístico de Mann-Whitney para as categorias comportamentais sociais são apresentadas na tabela 1. É observado nesta tabela que em todas as categorias do comportamento social, os valores de p não são significativos. É observado também que os valores de p não significativos para as duas categorias “aproximação de indivíduo sem tocar e ser aceito” ( $p=0,0645)$ e “receber toque de indivíduo e aceitar” $(\mathrm{P}=0,0606)$, mas se comparados com as outras categorias, eles estão muito abaixo em relação aos outros valores, sendo mais freqüente nas fêmeas do que nos machos (veja tabelas de freqüências 5 e 6), indicando assim uma possível tendência para o comportamento mais afiliativo das fêmeas. 
Tabela 1- Resultados comparativos entre os grupos de fêmeas e machos para as categorias comportamentais sociais.

Teste Mann-Whitney.

\begin{tabular}{|c|c|c|c|c|}
\hline & $\begin{array}{c}\text { Soma de Postos } \\
\text { F }\end{array}$ & $\begin{array}{c}\text { Soma de Postos } \\
\mathrm{M}\end{array}$ & $\mathrm{U}$ & $P$ \\
\hline $\begin{array}{l}1 \text { - Aprox. de indiv. sem tocar } \\
\text { e ser aceito }\end{array}$ & 519 & 301 & 130 & 0,0645 \\
\hline $\begin{array}{l}2 \text { - Aprox. de indiv. sem tocar } \\
\text { e ser evitado }\end{array}$ & 436 & 384 & 183 & 0,6834 \\
\hline $\begin{array}{l}3 \text { - Aprox. de indiv. com toque } \\
\text { e ser aceito }\end{array}$ & 444 & 376 & 191 & 0,8490 \\
\hline $\begin{array}{l}4 \text { - Aprox. de indiv. com toque } \\
\text { e ser evitado }\end{array}$ & 458 & 362 & 191 & 0,8490 \\
\hline $\begin{array}{l}5 \text { - Aprox. de } 2 \text { ou + indiv. } 1 \\
\text { ou + se retiram }\end{array}$ & 429 & 391 & 176 & 0,5497 \\
\hline $\begin{array}{l}6 \text { - Receber o toque de indiv. e } \\
\text { aceitar }\end{array}$ & 520 & 300 & 129 & 0,0606 \\
\hline $\begin{array}{l}7 \text { - Receber o toque de indiv. e } \\
\text { evitar }\end{array}$ & 451 & 369 & 198 & 1,0000 \\
\hline $\begin{array}{l}8 \text { - Parado ocorre aprox. de } \\
\text { indiv. este é aceito }\end{array}$ & 504 & 316 & 145 & 0,1496 \\
\hline $\begin{array}{l}9 \text { - Parado ocorre aprox. de } \\
\text { indiv. este é evitado }\end{array}$ & 463 & 356,5 & 185,5 & 0,7339 \\
\hline $\begin{array}{l}10 \text { - Parado encostado } 1 \text { ou + } \\
\text { indiv }\end{array}$ & 452 & 367,5 & 196,5 & 0,9674 \\
\hline $\begin{array}{l}11 \text { - Dormindo encostado } 1 \text { ou } \\
+ \text { indiv }\end{array}$ & 432 & 388 & 179 & 0,6054 \\
\hline 12 - Briga & 482 & 338 & 167 & 0,3993 \\
\hline 13 - Defesa & 446 & 373,5 & 193,5 & 0,9026 \\
\hline 14 - Vocalização rosnar & 476 & 344 & 173 & 0,4967 \\
\hline 15 - Vocalização receptor & 438 & 382 & 185 & 0,7237 \\
\hline 16 - Vocalização miar & 448 & 372 & 195 & 0,9349 \\
\hline 17 - Limpeza social & 409 & 411 & 156 & 0,2535 \\
\hline $\begin{array}{l}18 \text { - Autolimpeza encostado } 1 \\
\text { ou + indiv }\end{array}$ & 412 & 408 & 159 & 0,2890 \\
\hline
\end{tabular}

Veja descrição das categorias comportamentais sociais na página 22. 
As tabelas 5 e 6 de freqüências individuais mostram as freqüências das categorias sociais. Pode-se ver que a freqüência das categorias de aproximação, de toques aceitos e de contato entre os indivíduos são maiores do que quando ocorria a evitação, evidenciando assim as relações amigáveis entre os indivíduos tanto machos como as fêmeas. No entanto as freqüências das categorias não sociais parado sozinho, dormindo sozinho e autolimpeza sozinho (tabelas 7 e 8) são maiores que as categorias sociais equivalentes, parado, dormindo e autolimpeza em contato com outros animais (tabelas 5 e 6) indicando que apesar do espaço limitado os animais, machos e fêmeas ficavam distanciados um do outro, talvez assim evitando a proximidade.

Neste trabalho foi observado também baixas freqüências da categoria comportamental Briga (tabelas 5 e 6) entre os animais, apesar do espaço reduzido, e não houve diferença significativa entre machos e fêmeas em relação a categoria briga (tabela 1). Dessa forma a castração parece ter agido diminuindo a agressão em ambos os sexos.

Entretanto os valores brutos das freqüências individuais dos comportamentos sociais (veja tabelas 5 e 6) apresentam amplitudes distintas para os diferentes indivíduos (veja as categorias Vocalização rosnar e Briga (tabelas 5 e 6). A freqüência de 3 indivíduos fêmea (indivíduos 3, 17 e 22) foi maior em relação aos outros animais (veja Gráficos 1 e 2 de freqüências individuais). 


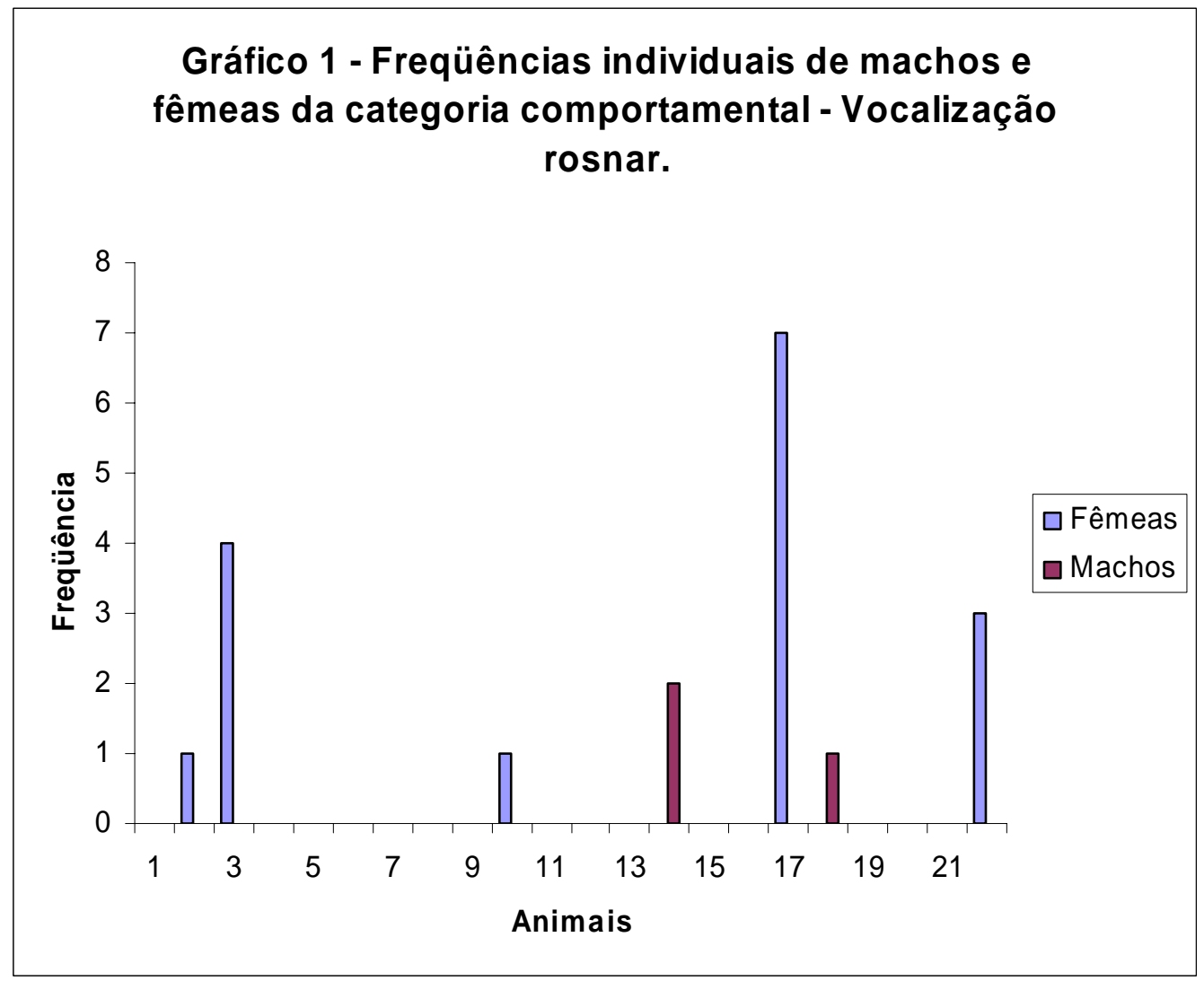




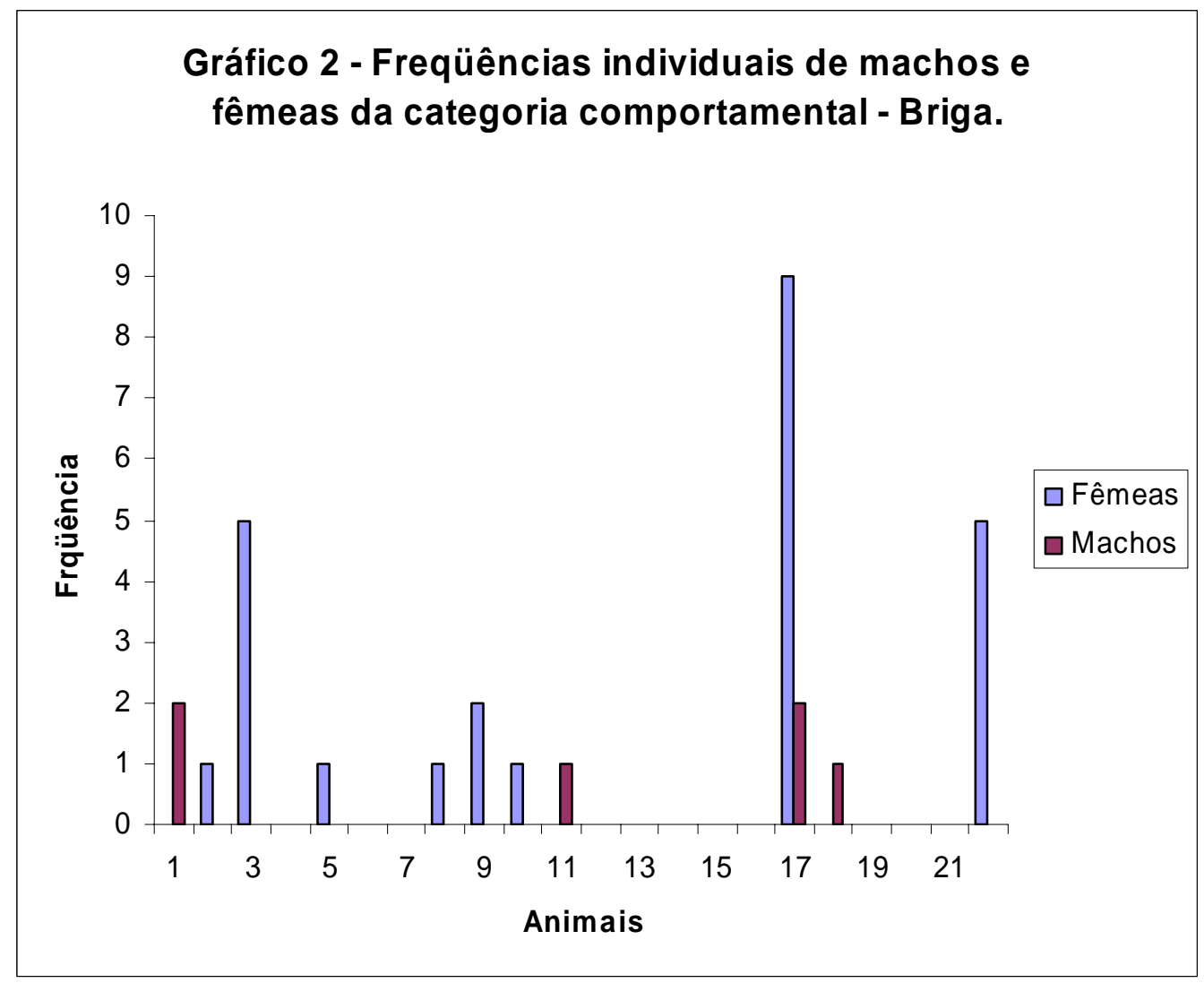


Tabela 5 - Freqüências individuais e total das categorias comportamentais sociais das fêmeas.

\begin{tabular}{|c|c|c|c|c|c|c|c|c|c|c|c|c|c|c|c|c|c|c|}
\hline Fêmeas & $\begin{array}{c}1- \\
\text { Aprox. } \\
\text { s/tocar } \\
\text { aceita }\end{array}$ & $\begin{array}{c}2- \\
\text { Aprox. } \\
\text { s/tocar } \\
\text { evitada }\end{array}$ & \begin{tabular}{|c|}
$3-$ \\
Aprox. \\
c/toque \\
aceita
\end{tabular} & \begin{tabular}{|c|} 
4- \\
Aprox. \\
c/toque \\
evitada
\end{tabular} & \begin{tabular}{|c}
$5-$ \\
Aprox. \\
$2+$ ind. \\
$1+$ se \\
retiram
\end{tabular} & \begin{tabular}{|c}
$6-$ \\
Receber \\
toque \\
aceitar
\end{tabular} & \begin{tabular}{|c} 
7- \\
Receber \\
toque \\
evitar
\end{tabular} & \begin{tabular}{|c|} 
8- \\
Parado \\
aprox. \\
aceita
\end{tabular} & \begin{tabular}{|c} 
9- \\
Parado \\
aprox. \\
evitada
\end{tabular} & \begin{tabular}{|c}
$10-$ \\
Parado \\
encost. \\
$1+$ ind.
\end{tabular} & \begin{tabular}{|c}
$11-$ \\
Dormir \\
encost. \\
$1+$ ind.
\end{tabular} & $\begin{array}{c}12- \\
\text { Briga }\end{array}$ & $\begin{array}{c}13- \\
\text { Defesa }\end{array}$ & $\begin{array}{l}14- \\
\text { Vocaliz. } \\
\text { rosnar }\end{array}$ & \begin{tabular}{|c|}
$15-$ \\
Vocaliz. \\
receptor
\end{tabular} & \begin{tabular}{|c|}
$16-$ \\
Vocaliz. \\
miar
\end{tabular} & $\begin{array}{c}17- \\
\text { Limpeza } \\
\text { social }\end{array}$ & $\begin{array}{c}18- \\
\text { Autolimpeza } \\
\text { encost. } 1+ \\
\text { indiv. }\end{array}$ \\
\hline Gato 1 & 2 & 0 & 6 & 0 & 0 & 4 & 0 & 4 & 0 & 4 & 3 & 0 & 0 & 0 & 0 & 0 & 0 & 2 \\
\hline Gato 2 & 0 & 0 & 1 & 1 & 0 & 1 & 0 & 2 & 0 & 4 & 3 & 1 & 0 & 1 & 0 & 0 & 0 & 0 \\
\hline Gato 3 & 0 & 0 & 5 & 0 & 0 & 1 & 1 & 1 & 5 & 4 & 0 & 5 & 1 & 4 & 0 & 0 & 1 & 2 \\
\hline Gato 4 & 1 & 0 & 0 & 0 & 0 & 2 & 0 & 2 & 0 & 4 & 6 & 0 & 0 & 0 & 0 & 0 & 0 & 2 \\
\hline Gato 5 & 0 & 0 & 2 & 0 & 0 & 2 & 1 & 2 & 0 & 1 & 5 & 1 & 0 & 0 & 0 & 0 & 0 & 1 \\
\hline Gato 6 & 3 & 0 & 2 & 0 & 0 & 3 & 0 & 3 & 0 & 0 & 0 & 0 & 0 & 0 & 0 & 0 & 1 & 3 \\
\hline Gato 7 & 3 & 0 & 6 & 0 & 0 & 2 & 0 & 4 & 0 & 6 & 3 & 0 & 0 & 0 & 0 & 0 & 0 & 3 \\
\hline Gato 8 & 0 & 1 & 1 & 1 & 0 & 2 & 0 & 1 & 0 & 0 & 2 & 1 & 2 & 0 & 0 & 0 & 0 & 0 \\
\hline Gato 9 & 0 & 0 & 4 & 0 & 0 & 2 & 2 & 3 & 1 & 3 & 1 & 2 & 1 & 0 & 0 & 0 & 0 & 0 \\
\hline Gato 10 & 2 & 2 & 8 & 0 & 0 & 3 & 0 & 3 & 0 & 6 & 1 & 1 & 0 & 1 & 1 & 0 & 0 & 6 \\
\hline Gato 11 & 2 & 0 & 2 & 0 & 0 & 2 & 0 & 3 & 0 & 1 & 6 & 0 & 0 & 0 & 0 & 0 & 0 & 1 \\
\hline Gato 12 & 0 & 1 & 1 & 0 & 0 & 1 & 0 & 1 & 0 & 3 & 2 & 0 & 0 & 0 & 0 & 0 & 0 & 1 \\
\hline Gato 13 & 0 & 0 & 3 & 0 & 0 & 2 & 0 & 5 & 0 & 0 & 0 & 0 & 0 & 0 & 0 & 1 & 0 & 0 \\
\hline Gato 14 & 2 & 0 & 1 & 0 & 0 & 1 & 0 & 1 & 0 & 1 & 3 & 0 & 0 & 0 & 0 & 0 & 0 & 0 \\
\hline Gato 15 & 3 & 0 & 5 & 0 & 0 & 2 & 0 & 3 & 0 & 5 & 5 & 0 & 1 & 0 & 0 & 2 & 1 & 8 \\
\hline Gato 16 & 0 & 0 & 4 & 0 & 0 & 1 & 0 & 1 & 1 & 2 & 0 & 0 & 1 & 0 & 0 & 0 & 0 & 0 \\
\hline Gato 17 & 0 & 0 & 1 & 0 & 0 & 1 & 0 & 1 & 2 & 1 & 6 & 9 & 0 & 7 & 0 & 0 & 0 & 3 \\
\hline Gato 18 & 2 & 0 & 4 & 0 & 0 & 3 & 0 & 11 & 0 & 5 & 4 & 0 & 0 & 0 & 0 & 0 & 0 & 1 \\
\hline Gato 19 & 1 & 0 & 1 & 0 & 0 & 0 & 0 & 1 & 1 & 5 & 5 & 0 & 0 & 0 & 0 & 0 & 0 & 1 \\
\hline Gato 20 & 1 & 0 & 4 & 0 & 0 & 3 & 0 & 3 & 0 & 2 & 1 & 0 & 0 & 0 & 0 & 0 & 0 & 2 \\
\hline Gato 21 & 1 & 0 & 0 & 0 & 0 & 2 & 1 & 2 & 0 & 2 & 0 & 0 & 1 & 0 & 0 & 0 & 0 & 0 \\
\hline Gato 22 & 2 & 0 & 1 & 0 & 0 & 0 & 1 & 0 & 2 & 5 & 2 & 5 & 0 & 3 & 0 & 2 & 0 & 0 \\
\hline Total & 25 & 4 & 62 & 2 & 0 & 39 & 6 & 58 & 12 & 64 & 58 & 25 & 7 & 16 & 1 & 5 & 3 & 35 \\
\hline
\end{tabular}

Veja lista da descrição das categorias comportamentais sociais na página 22. 
Tabela 6 - Freqüências individuais e total das categorias comportamentais sociais dos indivíduos machos.

\begin{tabular}{|c|c|c|c|c|c|c|c|c|c|c|c|c|c|c|c|c|c|c|}
\hline Machos & $\begin{array}{c}1- \\
\text { Aprox. } \\
\text { s/tocar } \\
\text { aceita }\end{array}$ & \begin{tabular}{|c}
$2-$ \\
Aprox. \\
s/tocar \\
evitada
\end{tabular} & \begin{tabular}{|c|}
$3-$ \\
Aprox. \\
c/toque \\
aceita
\end{tabular} & \begin{tabular}{|c|} 
4- \\
Aprox. \\
c/toque \\
evitada
\end{tabular} & \begin{tabular}{|c}
$5-$ \\
Aprox. \\
$2+$ ind. \\
$1+$ se \\
retiram
\end{tabular} & \begin{tabular}{|c|} 
6- \\
Receber \\
toque \\
aceitar
\end{tabular} & $\begin{array}{c}7- \\
\text { Receber } \\
\text { toque } \\
\text { evitar }\end{array}$ & \begin{tabular}{|c} 
8- \\
Parado \\
aprox. \\
aceita
\end{tabular} & \begin{tabular}{|c} 
9- \\
Parado \\
aprox. \\
evitada
\end{tabular} & $\begin{array}{c}10- \\
\text { Parado } \\
\text { encost. } \\
1+\text { ind. }\end{array}$ & \begin{tabular}{|c|}
$11-$ \\
Dormir \\
encost. \\
$1+$ ind.
\end{tabular} & \begin{tabular}{|c|}
$12-$ \\
Briga
\end{tabular} & $\begin{array}{c}13- \\
\text { Defesa }\end{array}$ & \begin{tabular}{|c}
$14-$ \\
Vocaliz. \\
rosnar
\end{tabular} & $\begin{array}{c}15- \\
\text { Vocaliz. } \\
\text { receptor }\end{array}$ & $\begin{array}{c}16- \\
\text { Vocaliz. } \\
\text { miar }\end{array}$ & \begin{tabular}{|c|}
$17-$ \\
Limpeza \\
social
\end{tabular} & $\begin{array}{c}18- \\
\text { Autolimpeza } \\
\text { encost. } 1+ \\
\text { indiv. }\end{array}$ \\
\hline Gato 1 & 1 & 1 & 3 & 0 & 0 & 0 & 1 & 0 & 1 & 0 & 1 & 2 & 1 & 0 & 0 & 1 & 0 & 0 \\
\hline Gato 2 & 0 & 0 & 1 & 0 & 0 & 0 & 0 & 0 & 0 & 2 & 1 & 0 & 0 & 0 & 0 & 0 & 1 & 0 \\
\hline Gato 3 & 0 & 0 & 3 & 0 & 1 & 0 & 0 & 0 & 0 & 3 & 6 & 0 & 0 & 0 & 0 & 0 & 0 & 4 \\
\hline Gato 4 & 0 & 0 & 1 & 0 & 0 & 2 & 0 & 2 & 0 & 2 & 5 & 0 & 0 & 0 & 0 & 0 & 3 & 5 \\
\hline Gato 5 & 0 & 0 & 3 & 0 & 0 & 0 & 0 & 0 & 0 & 1 & 2 & 0 & 0 & 0 & 0 & 0 & 0 & 1 \\
\hline Gato 6 & 0 & 0 & 1 & 0 & 0 & 1 & 0 & 0 & 0 & 3 & 2 & 0 & 0 & 0 & 0 & 0 & 0 & 2 \\
\hline Gato 7 & 0 & 1 & 1 & 0 & 0 & 3 & 0 & 3 & 0 & 3 & 4 & 0 & 1 & 0 & 0 & 0 & 0 & 1 \\
\hline Gato 8 & 1 & 0 & 4 & 0 & 0 & 1 & 0 & 3 & 0 & 0 & 3 & 0 & 1 & 0 & 0 & 0 & 0 & 0 \\
\hline Gato 9 & 2 & 0 & 5 & 1 & 0 & 1 & 0 & 1 & 0 & 6 & 3 & 0 & 0 & 0 & 0 & 0 & 0 & 5 \\
\hline Gato 10 & 0 & 0 & 5 & 0 & 0 & 0 & 0 & 3 & 0 & 6 & 4 & 0 & 0 & 0 & 0 & 0 & 0 & 2 \\
\hline Gato 11 & 0 & 0 & 1 & 0 & 0 & 2 & 0 & 1 & 0 & 0 & 1 & 1 & 0 & 0 & 0 & 1 & 0 & 0 \\
\hline Gato 12 & 1 & 0 & 1 & 0 & 0 & 4 & 0 & 3 & 0 & 1 & 5 & 0 & 0 & 0 & 0 & 0 & 1 & 2 \\
\hline Gato 13 & 0 & 0 & 4 & 0 & 0 & 0 & 0 & 1 & 0 & 8 & 6 & 0 & 0 & 0 & 0 & 0 & 0 & 4 \\
\hline Gato 14 & 2 & 1 & 4 & 0 & 0 & 3 & 0 & 4 & 0 & 4 & 0 & 0 & 0 & 2 & 0 & 0 & 1 & 6 \\
\hline Gato 15 & 0 & 0 & 2 & 0 & 0 & 2 & 1 & 2 & 0 & 2 & 4 & 0 & 0 & 0 & 0 & 0 & 0 & 1 \\
\hline Gato 16 & 0 & 0 & 2 & 0 & 0 & 1 & 0 & 2 & 1 & 0 & 0 & 0 & 0 & 0 & 0 & 1 & 1 & 0 \\
\hline Gato 17 & 1 & 1 & 13 & 0 & 1 & 1 & 3 & 2 & 3 & 9 & 2 & 2 & 2 & 0 & 1 & 0 & 3 & 4 \\
\hline Gato 18 & 0 & 0 & 2 & 0 & 0 & 0 & 1 & 2 & 1 & 8 & 4 & 1 & 2 & 1 & 1 & 0 & 0 & 4 \\
\hline Total & 8 & 4 & 56 & 1 & 2 & 21 & 6 & 29 & 6 & 49 & 53 & 6 & 7 & 3 & 2 & 3 & 10 & 39 \\
\hline
\end{tabular}

Veja lista da descrição das categorias comportamentais sociais na página 22. 


\subsubsection{Teste Estatístico das categorias não Sociais}

Novamente não houve diferenças significativas das categorias não sociais do comportamento, pois o valor de p não foi significativo para todas categorias, evidenciando assim as semelhanças comportamentais de machos e fêmeas (veja tabela 2).

Tabela 2 - Resultados comparativos entre os grupos de fêmeas e machos das categorias comportamentais não sociais - Teste Mann-Whitney.

\begin{tabular}{lcccc}
\hline & Soma de Postos & Soma de Postos & $\mathrm{U}$ & $p$ \\
& $\mathrm{~F}$ & $\mathrm{M}$ & & \\
\hline 1 - Locomoção & 458 & 362 & 191 & 0,8490 \\
2 - Observação & 462,5 & 357 & 186,5 & 0,7545 \\
3 - Dormindo sozinho & 413,5 & 406,5 & 160,5 & 0,3079 \\
4 - Parado sozinho & 486 & 334 & 163 & 0,3413 \\
5 - Autolimpeza sozinho & 508,5 & 311,5 & 140,5 & 0,1180 \\
6 - Vocalização inespecífica & 468,5 & 351,5 & 180,5 & 0,6342 \\
7 - Vocalização para humanos & 498 & 322, & 151 & 0,2013 \\
8 - Play & 494,5 & 325,5 & 154,5 & 0,2369 \\
9 - Esfregar e arranhar & 493,5 & 326,5 & 155,5 & 0,2479 \\
superfícies & & & & \\
10 - Alimentando & 488,5 & 331,5 & 160,5 & 0,3079 \\
11 - Beber água & 442 & 378 & 189 & 0,8067 \\
12 - Urinar defecar & 479 & 341 & 170 & 0,4465 \\
\hline
\end{tabular}

Veja descrição das categorias comportamentais não sociais na página 25.

Entretanto, a amplitude dos valores brutos das freqüências das categorias comportamentais não sociais (veja tabelas 7 e 8) é peculiar para cada indivíduo.

Os comportamentos observados com maior freqüência em ambos os sexos foram locomoção, parado sozinho (repouso), autolimpeza e observação, (veja tabelas 7 e 8 e gráficos 3, 4, 5 e 6). 
Tabela 7 - Freqüências individuais e total das categorias comportamentais não sociais das fêmeas.

\begin{tabular}{|c|c|c|c|c|c|c|c|c|c|c|c|c|}
\hline Fêmeas & $\begin{array}{c}1- \\
\text { Locomoção }\end{array}$ & $\begin{array}{c}2- \\
\text { Observação }\end{array}$ & $\begin{array}{c}3- \\
\text { Dormindo } \\
\text { sozinho }\end{array}$ & $\begin{array}{c}4- \\
\text { Parado } \\
\text { sozinho }\end{array}$ & $\begin{array}{c}5- \\
\text { Autolimpeza } \\
\text { sozinho }\end{array}$ & $\begin{array}{c}\text { 6- } \\
\text { Vocalização } \\
\text { inespecífica }\end{array}$ & \begin{tabular}{|c|}
$7-$ \\
Vocalização \\
para \\
humanos \\
\end{tabular} & $\begin{array}{c}- \\
\text { Play }\end{array}$ & $\begin{array}{c}\text { 9- } \\
\text { Esfregar e } \\
\text { Arranhar } \\
\text { superfícies }\end{array}$ & $\begin{array}{c}10- \\
\text { Alimentando }\end{array}$ & $\begin{array}{c}11- \\
\text { Beber água }\end{array}$ & $\begin{array}{c}12- \\
\text { Urinar } \\
\text { defecar }\end{array}$ \\
\hline Gato 1 & 71 & 14 & 6 & 14 & 10 & 10 & 0 & 2 & 0 & 1 & 0 & 0 \\
\hline Gato 2 & 6 & 6 & 13 & 3 & 7 & 0 & 0 & 1 & 1 & 1 & 0 & 0 \\
\hline Gato 3 & 55 & 14 & 1 & 17 & 13 & 13 & 1 & 0 & 0 & 2 & 4 & 0 \\
\hline Gato 4 & 6 & 11 & 4 & 8 & 9 & 1 & 1 & 0 & 0 & 0 & 0 & 0 \\
\hline Gato 5 & 13 & 7 & 5 & 6 & 10 & 2 & 0 & 0 & 0 & 0 & 2 & 1 \\
\hline Gato 6 & 37 & 4 & 4 & 8 & 22 & 0 & 0 & 0 & 1 & 0 & 5 & 1 \\
\hline Gato 7 & 49 & 16 & 2 & 17 & 20 & 0 & 0 & 0 & 0 & 5 & 2 & 0 \\
\hline Gato 8 & 5 & 6 & 8 & 5 & 8 & 2 & 0 & 0 & 0 & 1 & 0 & 0 \\
\hline Gato 9 & 86 & 7 & 2 & 24 & 13 & 11 & 3 & 0 & 0 & 6 & 3 & 0 \\
\hline Gato 10 & 157 & 9 & 3 & 20 & 20 & 42 & 8 & 1 & 3 & 3 & 1 & 0 \\
\hline Gato 11 & 17 & 5 & 8 & 17 & 7 & 1 & 1 & 0 & 0 & 4 & 3 & 0 \\
\hline Gato 12 & 19 & 12 & 6 & 13 & 13 & 18 & 0 & 0 & 1 & 1 & 0 & 0 \\
\hline Gato 13 & 22 & 6 & 9 & 19 & 24 & 5 & 2 & 3 & 0 & 3 & 8 & 0 \\
\hline Gato 14 & 22 & 5 & 4 & 16 & 7 & 4 & 1 & 0 & 0 & 2 & 0 & 1 \\
\hline Gato 15 & 66 & 0 & 2 & 19 & 9 & 6 & 2 & 4 & 0 & 1 & 2 & 1 \\
\hline Gato 16 & 33 & 5 & 1 & 9 & 18 & 0 & 0 & 5 & 2 & 2 & 5 & 1 \\
\hline Gato 17 & 15 & 5 & 6 & 19 & 11 & 3 & 2 & 0 & 0 & 1 & 0 & 1 \\
\hline Gato 18 & 6 & 1 & 3 & 11 & 14 & 0 & 0 & 0 & 0 & 0 & 0 & 0 \\
\hline Gato 19 & 48 & 11 & 5 & 8 & 6 & 0 & 0 & 0 & 0 & 1 & 0 & 2 \\
\hline Gato 20 & 11 & 13 & 6 & 10 & 11 & 0 & 0 & 0 & 0 & 1 & 0 & 0 \\
\hline Gato 21 & 36 & 16 & 4 & 18 & 20 & 0 & 0 & 0 & 0 & 4 & 2 & 0 \\
\hline Gato 22 & 32 & 5 & 3 & 28 & 12 & 16 & 2 & 0 & 3 & 0 & 0 & 0 \\
\hline Total & 812 & 178 & 105 & 309 & 284 & 134 & 25 & 16 & 11 & 39 & 37 & 8 \\
\hline
\end{tabular}

Veja lista da descrição das categorias comportamentais não sociais na página 25. 
Tabela 8 - Freqüências individuais e total das categorias comportamentais não sociais dos indivíduos machos.

\begin{tabular}{|c|c|c|c|c|c|c|c|c|c|c|c|c|}
\hline Machos & $\begin{array}{c}1- \\
\text { Locomoção }\end{array}$ & $\begin{array}{c}2- \\
\text { Observação }\end{array}$ & $\begin{array}{c}- \\
\text { Dormindo } \\
\text { sozinho }\end{array}$ & $\begin{array}{c}- \\
\text { Parado } \\
\text { sozinho }\end{array}$ & $\begin{array}{c}5- \\
\text { Autolimpeza } \\
\text { sozinho }\end{array}$ & $\begin{array}{c}6- \\
\text { Vocalização } \\
\text { inespecífica }\end{array}$ & \begin{tabular}{|c|}
$7-$ \\
Vocalização \\
para \\
humanos \\
\end{tabular} & $\begin{array}{c}8- \\
\text { Play }\end{array}$ & $\begin{array}{c}9- \\
\text { Esfregar e } \\
\text { Arranhar } \\
\text { superfícies }\end{array}$ & $\begin{array}{c}10- \\
\text { Alimentando }\end{array}$ & $\begin{array}{c}11- \\
\text { Beber água }\end{array}$ & $\begin{array}{c}12- \\
\text { Urinar } \\
\text { defecar }\end{array}$ \\
\hline Gato 1 & 143 & 10 & 6 & 21 & 25 & 12 & 0 & 0 & 0 & 0 & 1 & 0 \\
\hline Gato 2 & 5 & 10 & 10 & 8 & 11 & 2 & 0 & 0 & 2 & 0 & 0 & 0 \\
\hline Gato 3 & 22 & 4 & 2 & 11 & 3 & 1 & 0 & 0 & 0 & 1 & 1 & 0 \\
\hline Gato 4 & 11 & 11 & 4 & 9 & 4 & 5 & 0 & 0 & 0 & 0 & 1 & 0 \\
\hline Gato 5 & 16 & 7 & 3 & 6 & 14 & 0 & 0 & 0 & 0 & 2 & 3 & 0 \\
\hline Gato 6 & 14 & 0 & 7 & 5 & 6 & 1 & 0 & 0 & 0 & 2 & 0 & 0 \\
\hline Gato 7 & 26 & 1 & 5 & 10 & 6 & 3 & 0 & 0 & 0 & 3 & 2 & 0 \\
\hline Gato 8 & 28 & 8 & 6 & 18 & 11 & 0 & 0 & 0 & 0 & 0 & 3 & 0 \\
\hline Gato 9 & 68 & 8 & 0 & 9 & 12 & 10 & 4 & 0 & 0 & 3 & 1 & 0 \\
\hline Gato 10 & 14 & 10 & 8 & 8 & 9 & 3 & 1 & 0 & 0 & 2 & 1 & 2 \\
\hline Gato 11 & 14 & 8 & 14 & 9 & 7 & 2 & 0 & 0 & 0 & 0 & 0 & 1 \\
\hline Gato 12 & 38 & 10 & 8 & 15 & 20 & 0 & 0 & 0 & 0 & 1 & 1 & 0 \\
\hline Gato 13 & 17 & 15 & 6 & 10 & 9 & 8 & 0 & 2 & 0 & 0 & 0 & 0 \\
\hline Gato 14 & 21 & 9 & 7 & 7 & 11 & 0 & 0 & 0 & 0 & 2 & 1 & 0 \\
\hline Gato 15 & 17 & 4 & 4 & 16 & 8 & 0 & 0 & 0 & 0 & 1 & 2 & 0 \\
\hline Gato 16 & 43 & 12 & 12 & 23 & 7 & 6 & 1 & 0 & 0 & 0 & 2 & 1 \\
\hline Gato 17 & 44 & 3 & 3 & 19 & 21 & 0 & 0 & 0 & 0 & 6 & 3 & 0 \\
\hline Gato 18 & 81 & 5 & 0 & 11 & 6 & 2 & 2 & 0 & 0 & 0 & 1 & 0 \\
\hline Total & 622 & 145 & 105 & 215 & 190 & 55 & 8 & 2 & 2 & 23 & 23 & 4 \\
\hline
\end{tabular}

Veja lista da descrição das categorias comportamentais não sociais na página 25. 


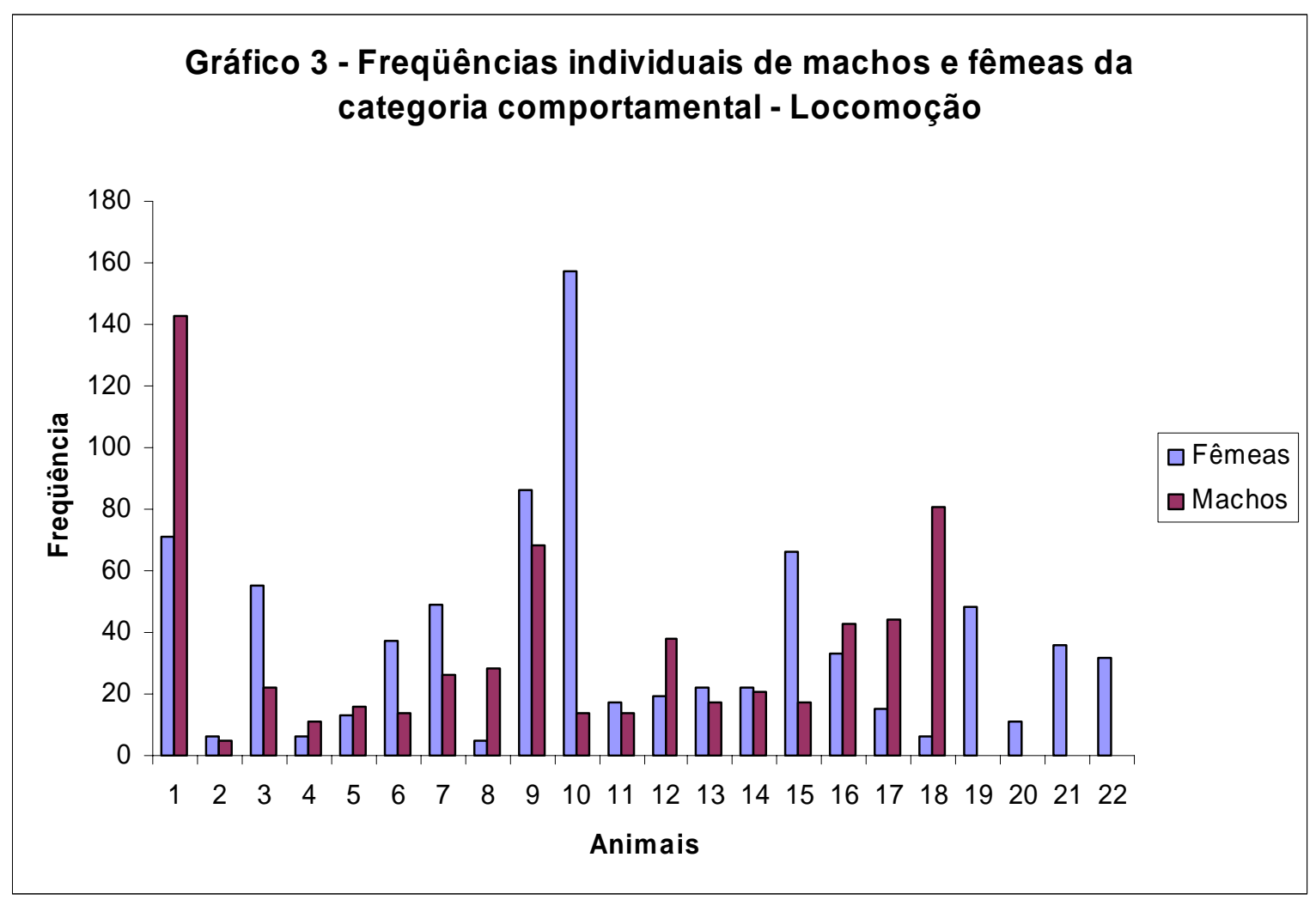




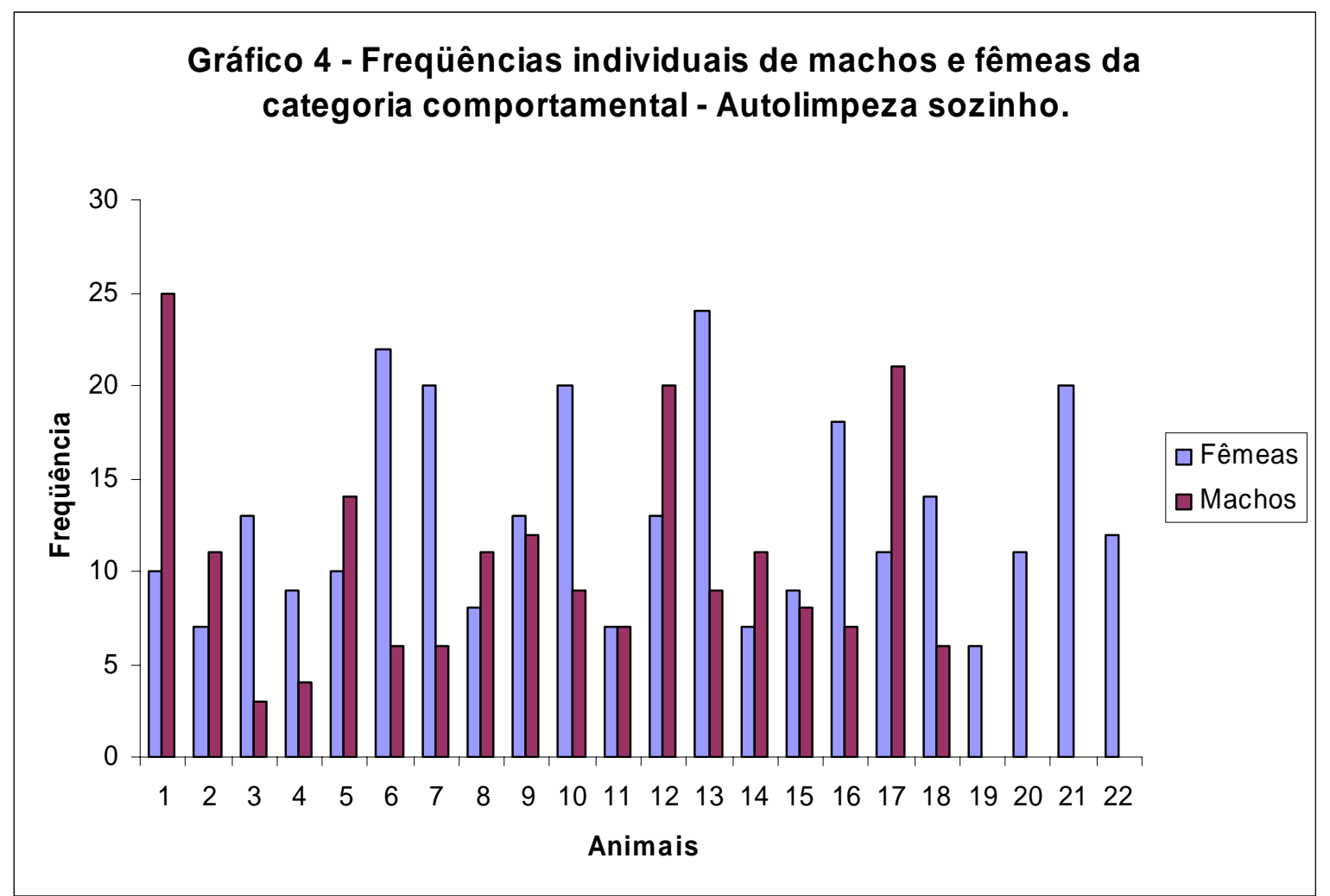




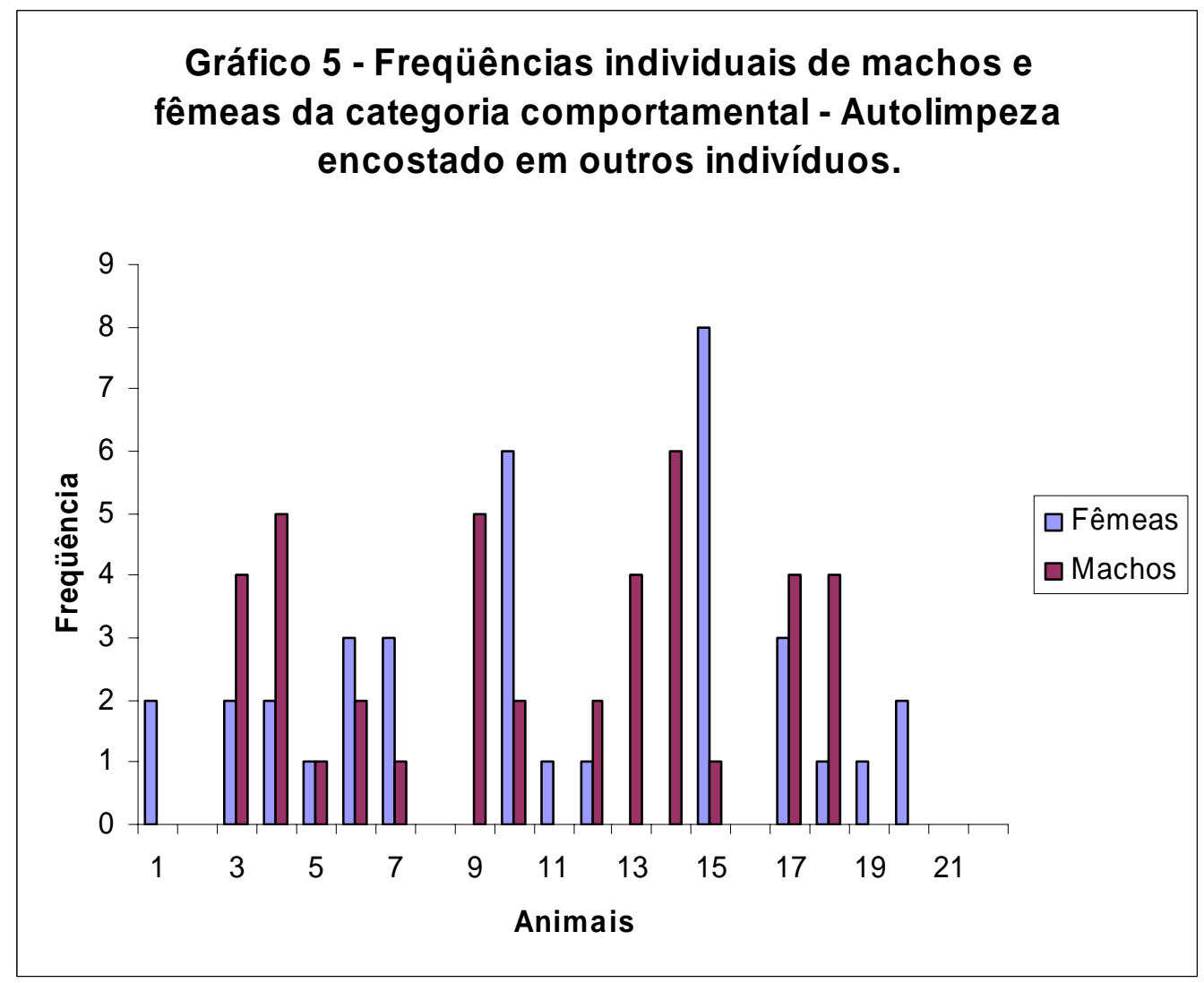




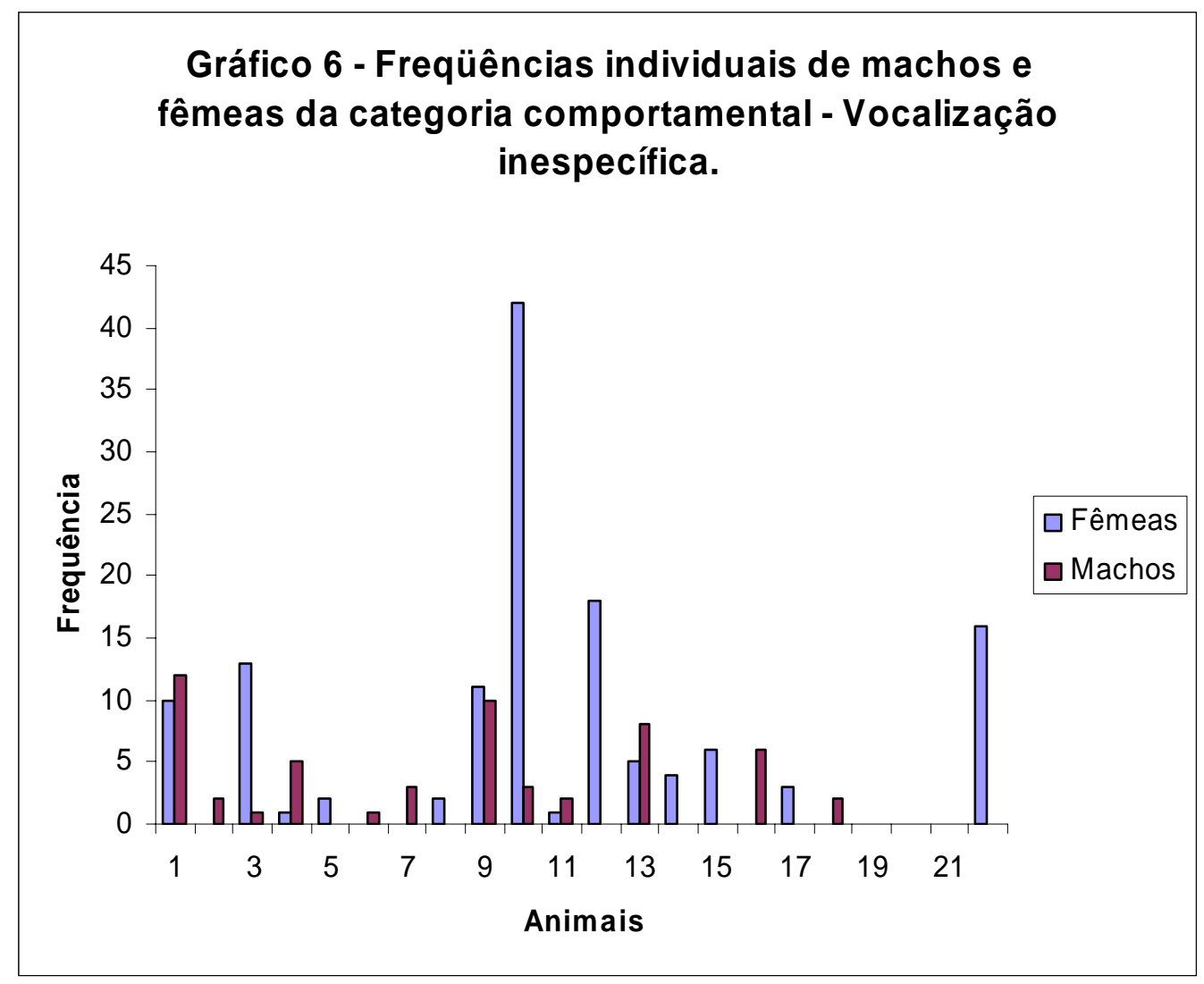

\subsubsection{Teste Estatístico dos Locais}

Novamente não houve diferenças sexuais em relação a todos os locais (veja tabela 3), no entanto há locais favoritos para diferentes animais, como as tábuas de madeira do gatil direito e esquerdo e o solo direito e esquerdo também (veja tabela 4 e anexo 1). A partir dessa observação, foi feito um segundo teste estatístico separando os locais que apresentaram maiores freqüências (como as tábuas de madeira do gatil direito e esquerdo e o solo direito e esquerdo) dos locais que apresentaram menores freqüências (como as muretas, outras regiões do solo, bancos e cadeiras - veja lista dos locais na pg. 15 e tabela 4) com o objetivo de descobrir se há diferenças entre os sexos no acesso aos locais preferenciais. Mas novamente o teste mostrou que não 
houve diferença significativa entre machos e fêmeas no acesso aos locais preferenciais (veja tabela 3.1).

Tabela 3 - Resultados comparativos dos grupos de fêmeas e machos em relação aos locais - Teste Mann-Whitney.

\begin{tabular}{|c|c|c|c|c|}
\hline & $\begin{array}{c}\text { Soma de Postos } \\
\text { F }\end{array}$ & $\begin{array}{c}\text { Soma de Postos } \\
\text { M }\end{array}$ & $\mathrm{U}$ & $p$ \\
\hline Tábua E1 & 459 & 361 & 190 & 0,8278 \\
\hline Tábua E2 & 485,5 & 334,5 & 163,5 & 0,3482 \\
\hline Tábua E3 & 447,5 & 372,5 & 194,5 & 0,9241 \\
\hline Tábua D1 & 435 & 385 & 182 & 0,6635 \\
\hline Tábua D2 & 458 & 362 & 191 & 0,8490 \\
\hline Tábua D3 & 465 & 355 & 184 & 0,7034 \\
\hline Mureta lat. direita G. D. & 467 & 353 & 182 & 0,6635 \\
\hline Mureta lat. direita G. E. & 484,5 & 335,5 & 164,5 & 0,3624 \\
\hline Mureta lat. esquerda G. E. & 503,50 & 316,5 & 145,5 & 0,1535 \\
\hline Mureta lat. esquerda G. D. & 518,5 & 301,5 & 130,5 & 0,0665 \\
\hline Banco G. D. & 438,5 & 381,5 & 185,5 & 0,7339 \\
\hline Banco G. E. & 433, & 387 & 180 & 0,6245 \\
\hline Solo G. D. & 439,5 & 380,5 & 186,5 & 0,7545 \\
\hline Solo G. E. & 443,5 & 376,5 & 190,5 & 0,8384 \\
\hline Solo porta lat. direita G. D. & 506 & 314 & 143 & 0,1348 \\
\hline Solo porta lat. esquerda GE. & 460 & 360 & 189 & 0,8067 \\
\hline Solo porta meio G. D. & 460,5 & 359,5 & 188,5 & 0,7962 \\
\hline Solo porta meio G. E. & 450 & 370 & 197 & 0,9783 \\
\hline Solo pote água G. D. & 446 & 374 & 193 & 0,8918 \\
\hline Solo pote água G. E. & 428 & 392 & 175 & 0,5317 \\
\hline Cestas G. D. & 444 & 376 & 191 & 0,8490 \\
\hline Cestas G. E. & 489 & 331 & 160 & 0,3015 \\
\hline Cadeiras G. D. & 445,5 & 374 & 192,5 & 0,8811 \\
\hline Cadeiras G. E. & 427 & 393 & 174 & 0,5141 \\
\hline
\end{tabular}

Legenda - E (Esquerdo), D (Direito), 1, 2, 3 (localizações diferentes das tábuas esquerda e deireita), G.D. (Gatil Direito), G. E. (Gatil Esquerdo). 
Tabela 3.1 - Resultados comparativos dos grupos de fêmeas e machos em relação aos locais - Teste Mann-Whitney.

\begin{tabular}{lcccc}
\hline & Soma de Postos & Soma de Postos & U & $p$ \\
& $\mathrm{~F}$ & $\mathrm{M}$ & & \\
\hline Local 1 & 489 & 330 & 159 & 0,2952 \\
Local 2 & 500 & 319 & 148 & 0,1784 \\
\hline
\end{tabular}

Legenda - Local 1 compreende (Tábua E1, Tábua E2, Tábua E3, Tábua D1, Tábua D2,

Tábua D3, Solo G. D., Solo G. E., Cestas G. D.), Local 2 compreende (Mureta lat. direita G.

D., Mureta lat. direita G. E., Mureta lat. esquerda G. E., Mureta lat. esquerda G. D., Banco G.

D., Banco G. E., Solo porta lat. direita G. D., Solo porta lat. esquerda GE., Solo porta meio G.

D., Solo porta meio G. E., Solo pote água G. D., Solo pote água G. E., Cestas G. E., Cadeiras G.

D., Cadeiras G. E.).

Tabela 4 - Freqüências dos locais freqüentados por machos e fêmeas.

\begin{tabular}{lcc}
\hline $\begin{array}{l}\text { Estados } \\
\text { Comportamentais - Locais }\end{array}$ & $\begin{array}{c}\text { Freqüência } \\
\text { Fêmeas }\end{array}$ & $\begin{array}{c}\text { Freqüência } \\
\text { Machos }\end{array}$ \\
\hline Tábua E1 & 223 & 135 \\
Tábua E2 & 262 & 174 \\
Tábua E3 & 227 & 160 \\
Tábua D1 & 194 & 148 \\
Tábua D2 & 176 & 136 \\
Tábua D3 & 192 & 181 \\
Mureta lat. direita G. D. & 67 & 36 \\
Mureta lat. direita G. E. & 30 & 11 \\
Mureta lat. esquerda G. E. & 109 & 46 \\
Mureta lat. esquerda G. D. & 21 & 6 \\
Banco G. D. & 6 & 4 \\
Banco G. E. & 12 & 18 \\
Solo G. D. & 178 & 135 \\
Solo G. E. & 295 & 203 \\
Solo porta lat. direita G. D. & 28 & 1 \\
Solo porta lat. esquerda GE. & 42 & 12 \\
Solo porta meio G. D. & 14 & 11 \\
Solo porta meio G. E. & 31 & 23 \\
Solo pote água G. D. & 33 & 20 \\
Solo pote água G. E. & 99 & 69 \\
Cestas G. D. & 106 & 88 \\
Cestas G. E. & 75 & 53 \\
Cadeiras G. D. & 5 & 11 \\
Cadeiras G. E. & 6 & 19 \\
\hline
\end{tabular}

Legenda - E (Esquerdo), D (Direito), 1,2,3 (localizações diferentes das tábuas esquerda e deireita), G.D. (Gatil Direito), G. E. (Gatil Esquerdo). 


\subsection{Seqüência Comportamental}

As Ditrees (árvores orientadas) de cada categoria comportamental são formadas por uma categoria do comportamento como raiz e a partir desta, a probabilidade de ocorrência de todas as outras categorias comportamentais.

No entanto as árvores aqui mostradas são aquelas nas quais a probabilidade de ocorrência de díades (duas seqüências consecutivas) comportamentais são maiores que $0,5 \%$. Para um maior entendimento das categorias comportamentais das Ditrees veja lista das categorias nas pgs. 22 a 26.

As figuras 1.A e 1.B se referem às Ditrees da categoria comportamental Alimentar-se (Alimentand) das fêmeas e dos machos respectivamente. A figura 1.A mostra a díade estatisticamente significante \{locomoção $(0,85)$ - autolimpeza $(0,52)$, enquanto que os machos (Fig. 1.B) mostrou a díade \{autolimpeza $(0,67$ locomoção $(0,58)\}$. Conferindo assim seqüências comportamentais diferentes para fêmeas e para os machos em relação a esta categoria comportamental.

As figuras 2.A (Fêmeas) e 2.B (Machos) se referem a categoria comportamental “Aproctoace” (Aproximação de outro indivíduo com toque aceita) (veja lista das categorias sociais). A figura 1.A mostra que depois da categoria raiz a probabilidade de ocorrência de uma díade estatisticamente significante é \{locomoção $(0,78)$ pard1+ind (0,72)\}. Enquanto que para os machos (Fig. 2.B) há um tríade estatisticamente significante \{locomoção $(1,00)$ - autlimpzju $(0,92)$ - (pard1+ind $(0,72)\}$. As diferenças das seqüências comportamentais de fêmeas e machos é que neste último há a presença de outra categoria (autlimpzju 0,92), enquanto que nas fêmeas esta categoria ocorre depois de pard1+ind $(0,72)$ e não é estatisticamente significante $(0,39)$.

Conferindo assim diferenças para fêmeas e para os machos em relação a esta categoria. 
alimentand

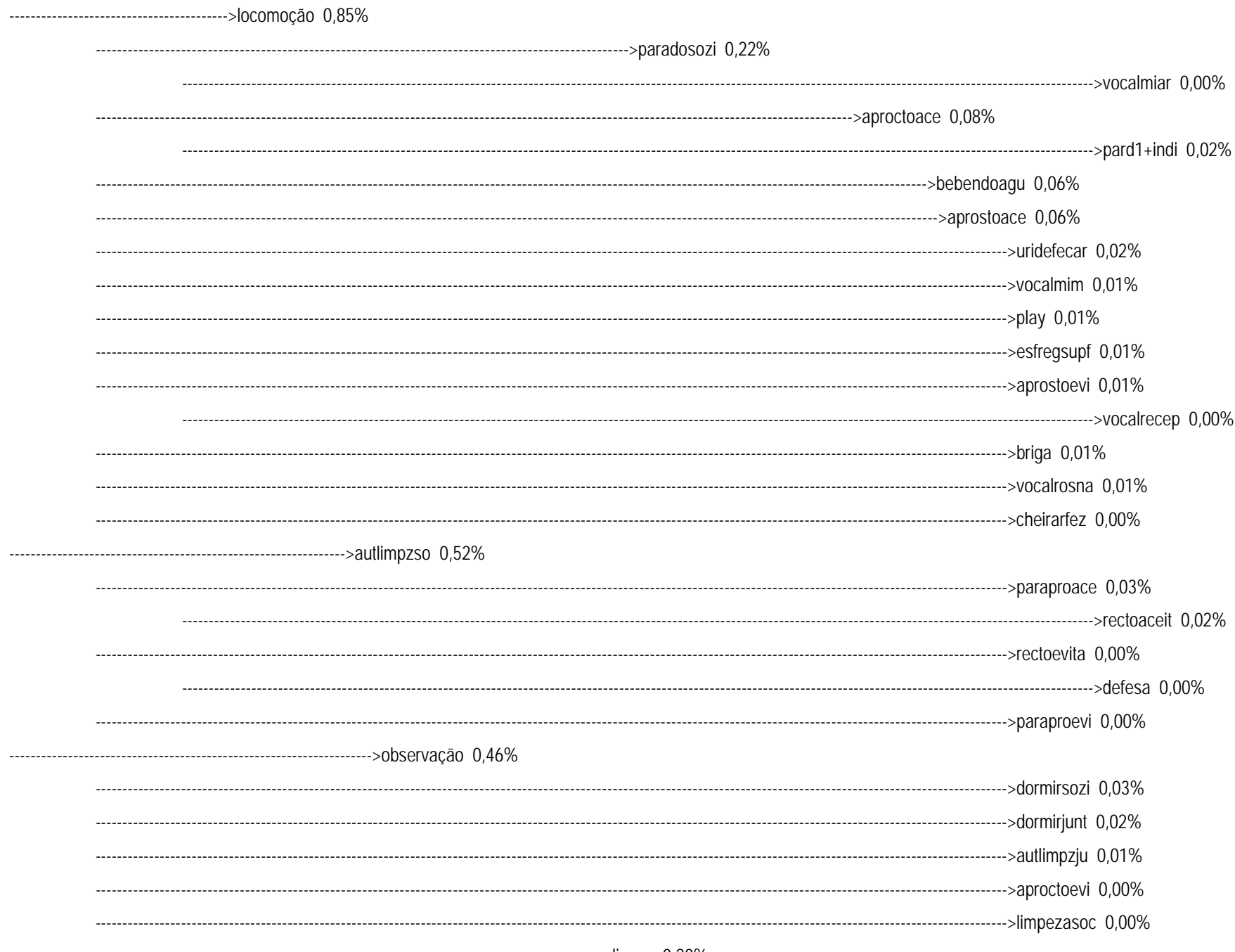

-->vocalinesp 0,20\%

Figura 1.A - Ditree da categoria comportamental “Alimentar-se” do grupo das fêmeas. 
alimentand

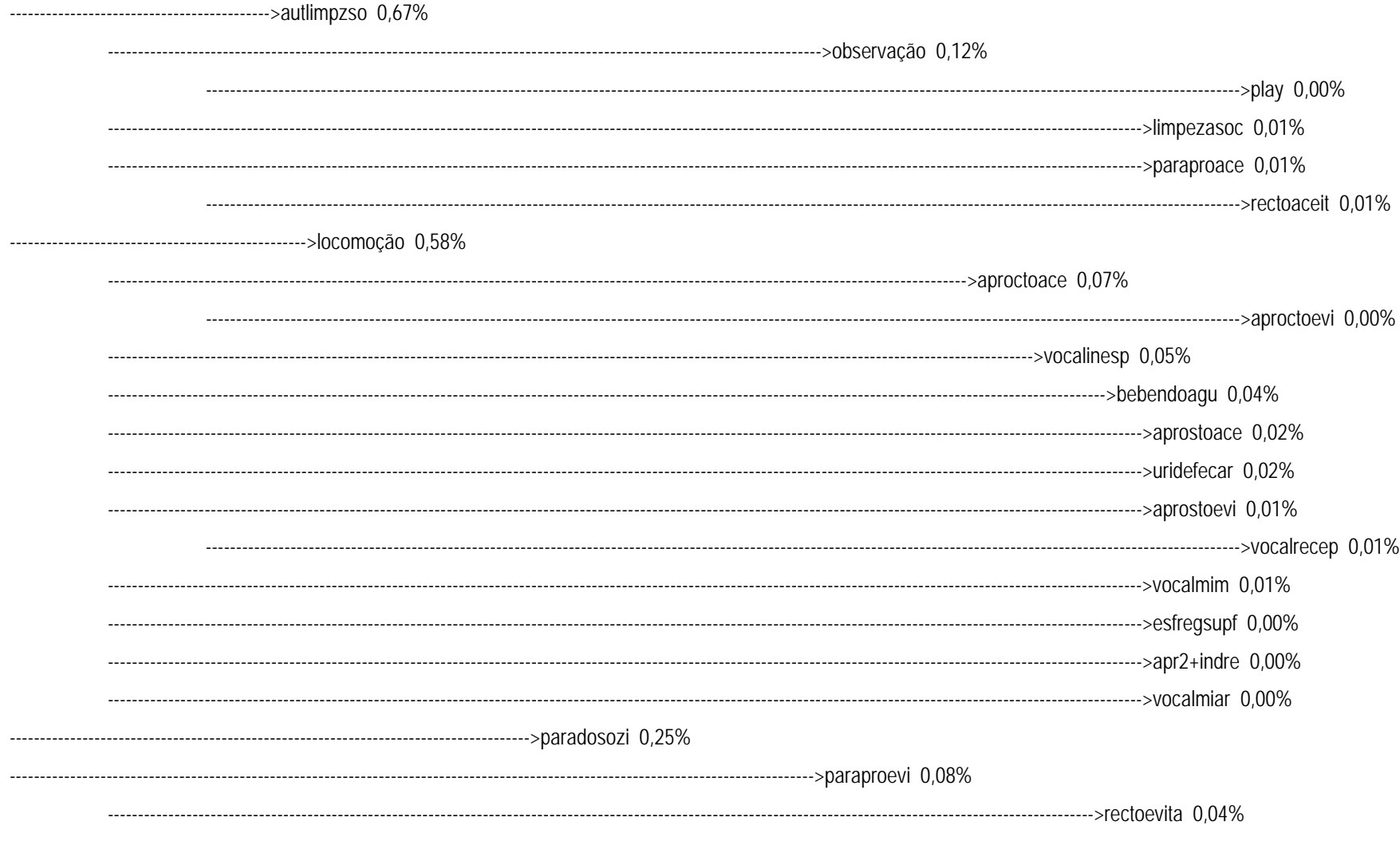

Figura 1.B - Ditree da categoria comportamental “Alimentar-se” do grupo dos machos. 
aproctoace

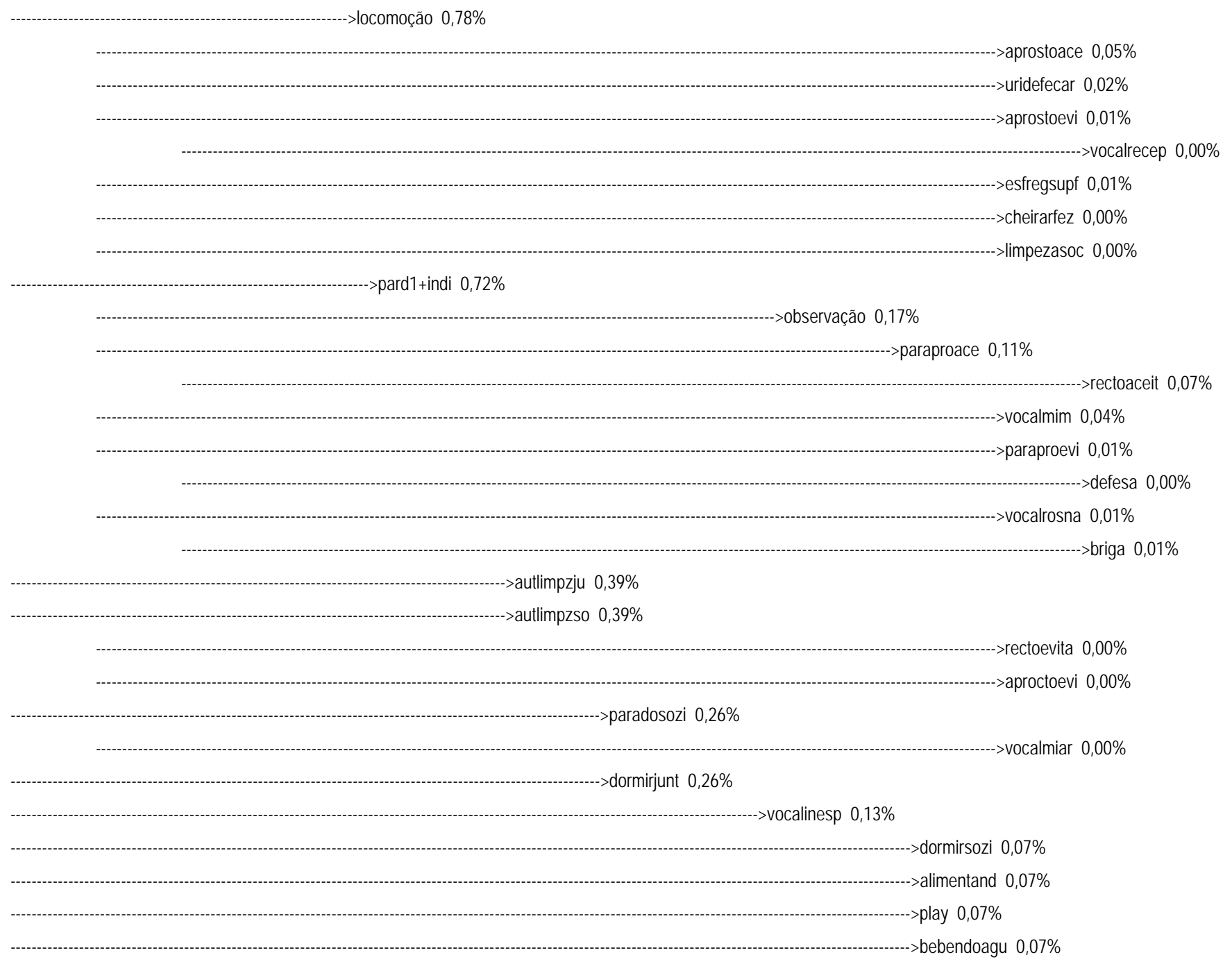

Figura 2.A - Ditree da categoria comportamental “Aproximação de outro animal com toque aceita” do grupo das fêmeas. 
aproctoace

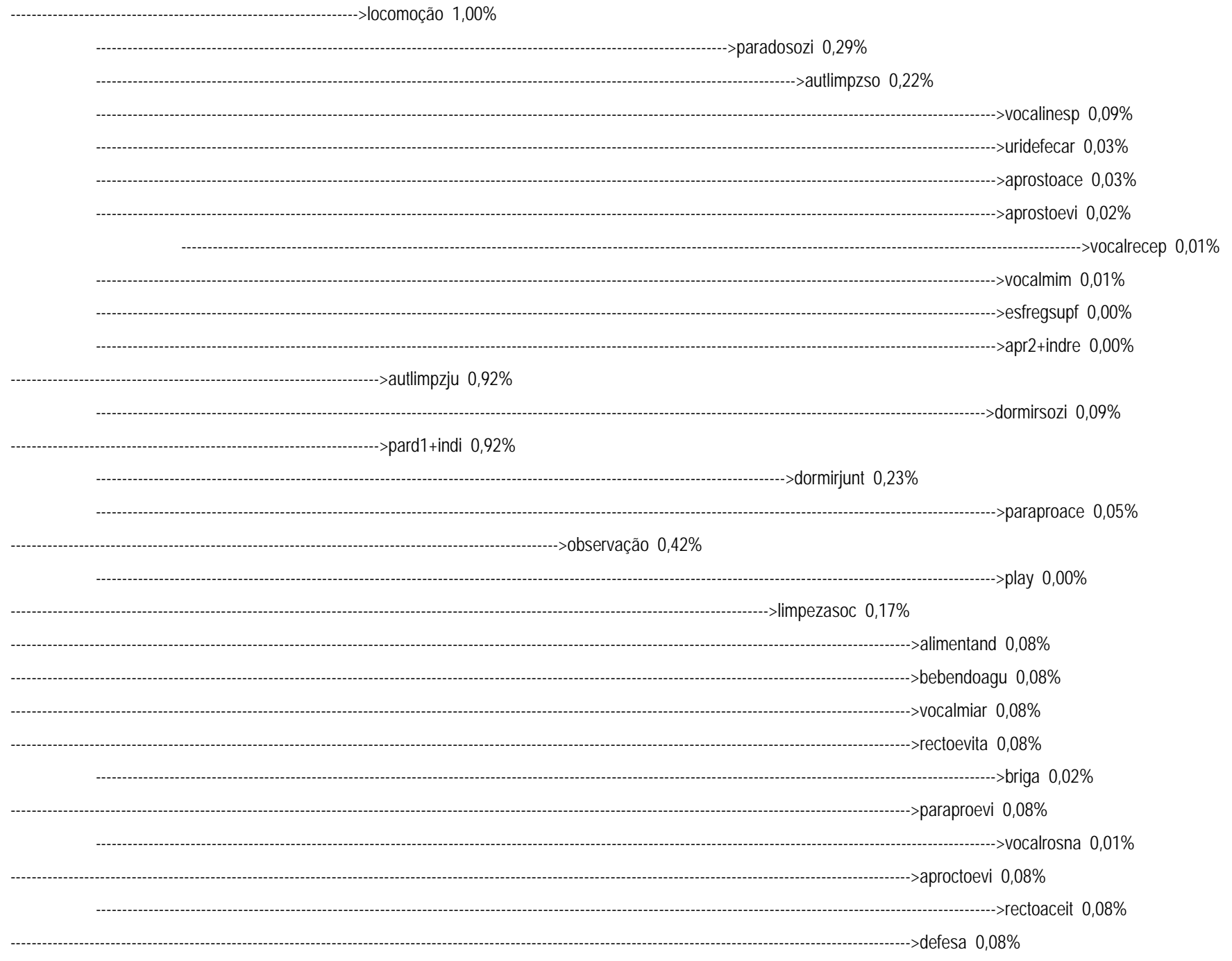

Figura 2.B - Ditree da categoria comportamental “Aproximação de outro animal com toque aceita” do grupo dos machos. 
As figuras 3.A (Fêmeas) e 3.B (Machos) se referem a categoria comportamental “Aproctoace” (Aproximação de outro indivíduo com toque aceita). A figura 3.A não apresenta nenhuma díade significante estatisticamente, assim como a figura 3. B. Em ambos fêmeas e machos, depois da categoria comportamental raiz vem em seguida a categoria “Paradosozi” (Parado sozinho) com probabilidade de $(0,85)$ para as fêmeas e $(0,50)$ para os machos, não conferindo assim diferença entre ambos.

As figuras 4.A (Fêmeas) e 4.B (Machos) se referem a categoria comportamental “Autlimpzju” (Autolimpeza encostado em outros indivíduos). As fêmeas não apresentaram díades significantes estatisticamente, o comportamento mais provável depois da categoria raiz foi "pard1+ind" $(0,46)$, após este foi locomoção $(0,33)$ e depois de locomoção “dormirjunt” $(0,20)$. Enquanto que os machos mostraram a mesma tríade, mas com probabilidades estatisticamente significantes, sendo $(1,09)$, $(0,50)$ e $(0,50)$.

As figuras 5.A (Fêmeas) e 5.B (Machos) se referem a categoria comportamental “Autlimpzso" (Autolimpeza sozinho). As fêmeas mostraram a seguinte seqüência comportamental, \{locomoção (4,03), observação $(3,19)$, paradosozi $(2,80)$, paraproace (085)- rectoaceit $(0,53)$, vocalinesp $(0,65)$ e aproctoace $(0,52)\}$. Enquanto que os machos mostraram, \{locomoção $(4,43)$, paradosozi $(3,17)$, observação $(2,51)$, dormirsozi $(1,25)$, aproctoace $(0,67)$, alimentand $(0,58)$ e vocalinesp $(0,50)\}$. Ambos começam a seqüência depois da categoria raiz com locomoção, mas as seqüências comportamentais seguintes diferem na ordem probabilística apesar de apresentarem 4 comportamentos iguais em tal seqüência. Isto é um indício de diferenças nas seqüências comportamentais de machos e fêmeas em relação a esta categoria raiz. 
aprostoace

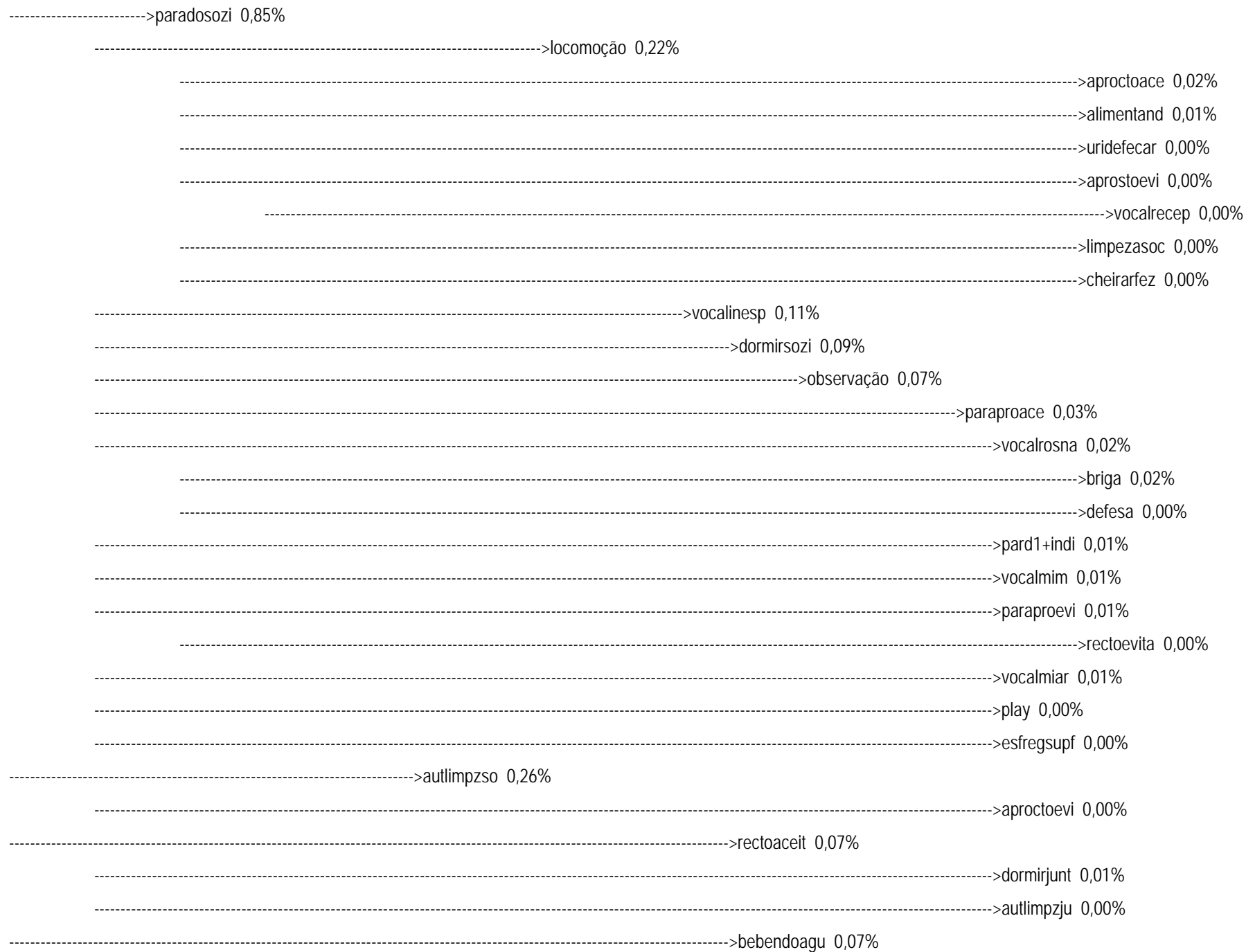

Figura 3.A - Ditree da categoria comportamental “Aproximação de outro animal sem toque aceita” do grupo das fêmeas. 
aprostoace

----------->paradosozi 0,50\%

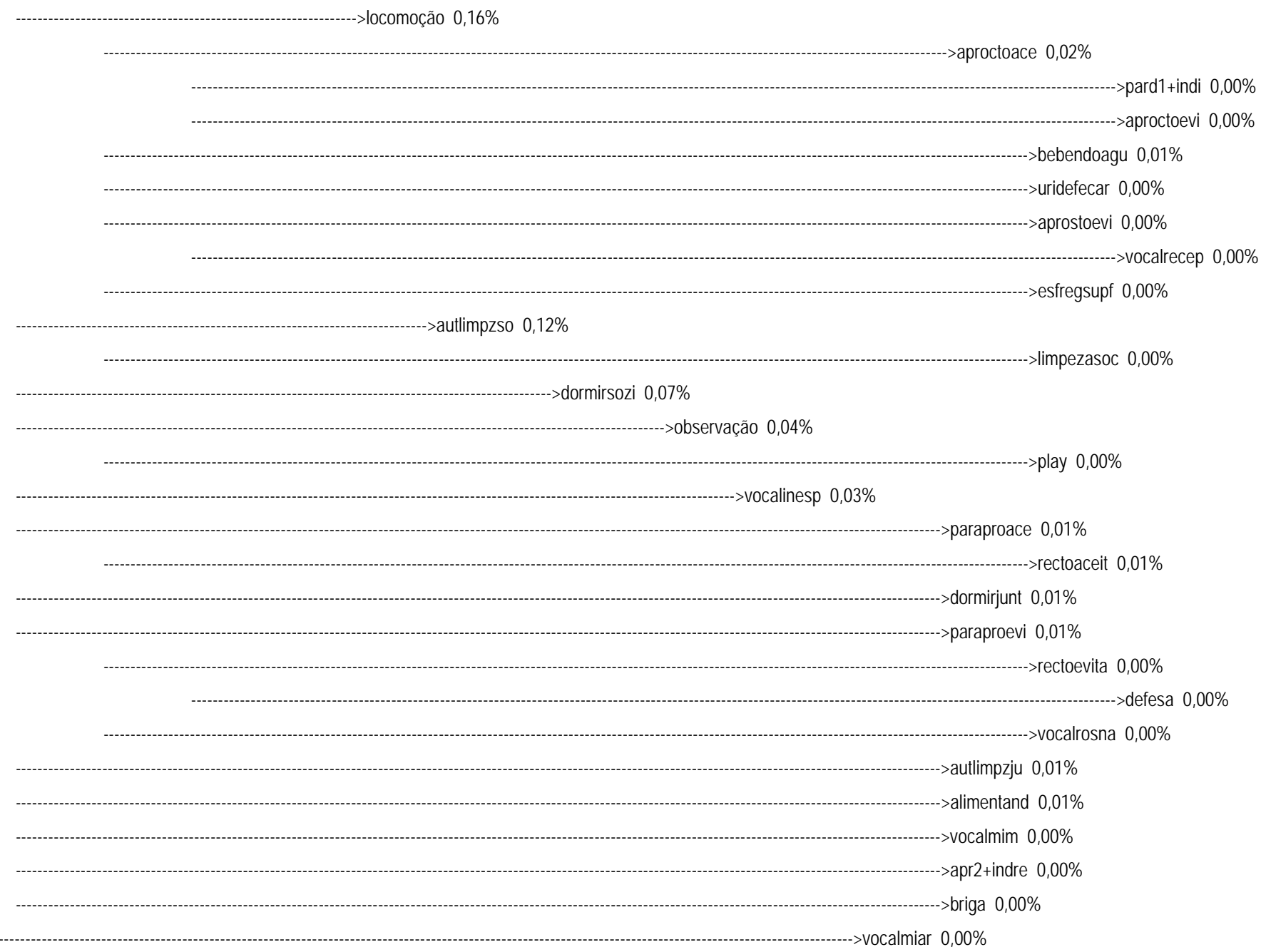

3.B - Ditree da categoria comportamental “Aproximação de outro animal sem toque aceita” do grupo dos machos. 
autlimpzju

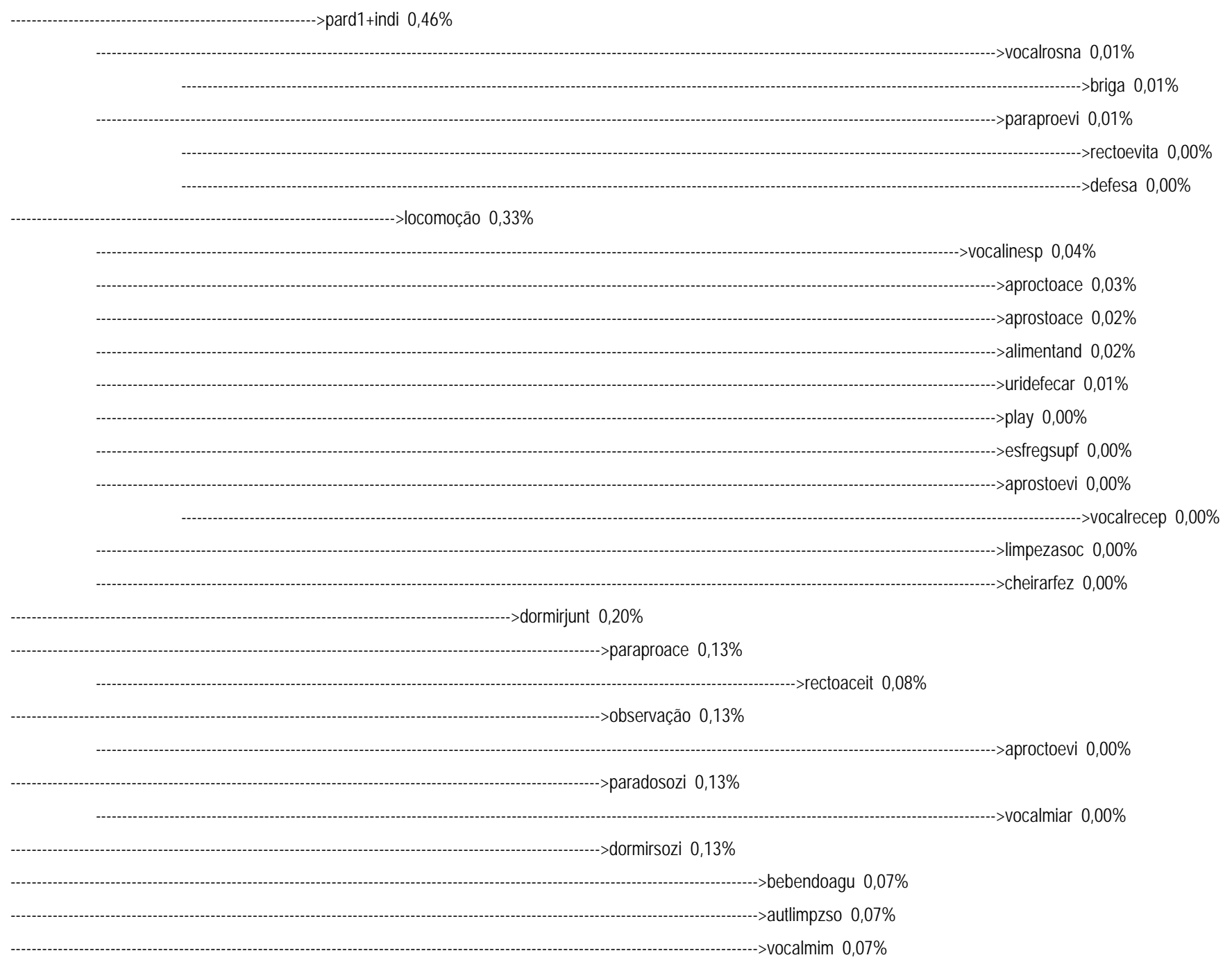

Figura 4.A - Ditree da categoria comportamental “Autolimpeza encostado em outro animal” do grupo das fêmeas. 
autlimpzju
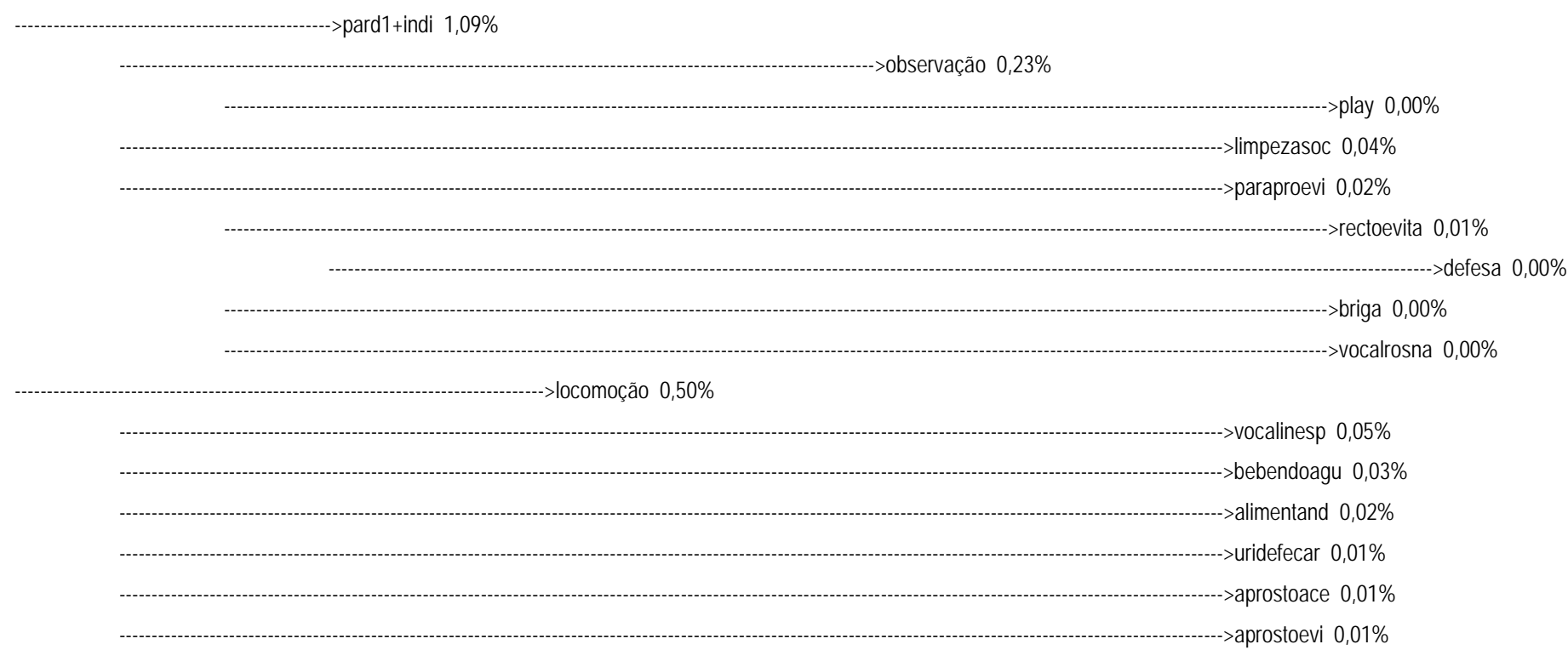

$>$ aprostoevi $0,01 \%$

-->vocalmim 0,01\%

-->vocalmiar $0,00 \%$

-.>esfregsupf $0,00 \%$

-->apr2+indre $0,00 \%$

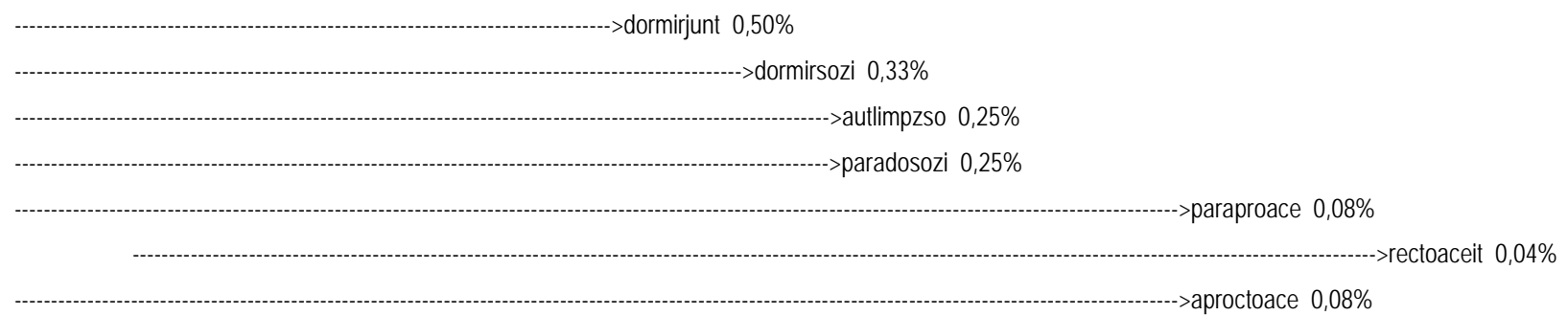

$>$ aproctoevi $0,00 \%$

Figura 4.B - Ditree da categoria comportamental “Autolimpeza encostado em outro animal” do grupo dos machos. 
autlimpzso

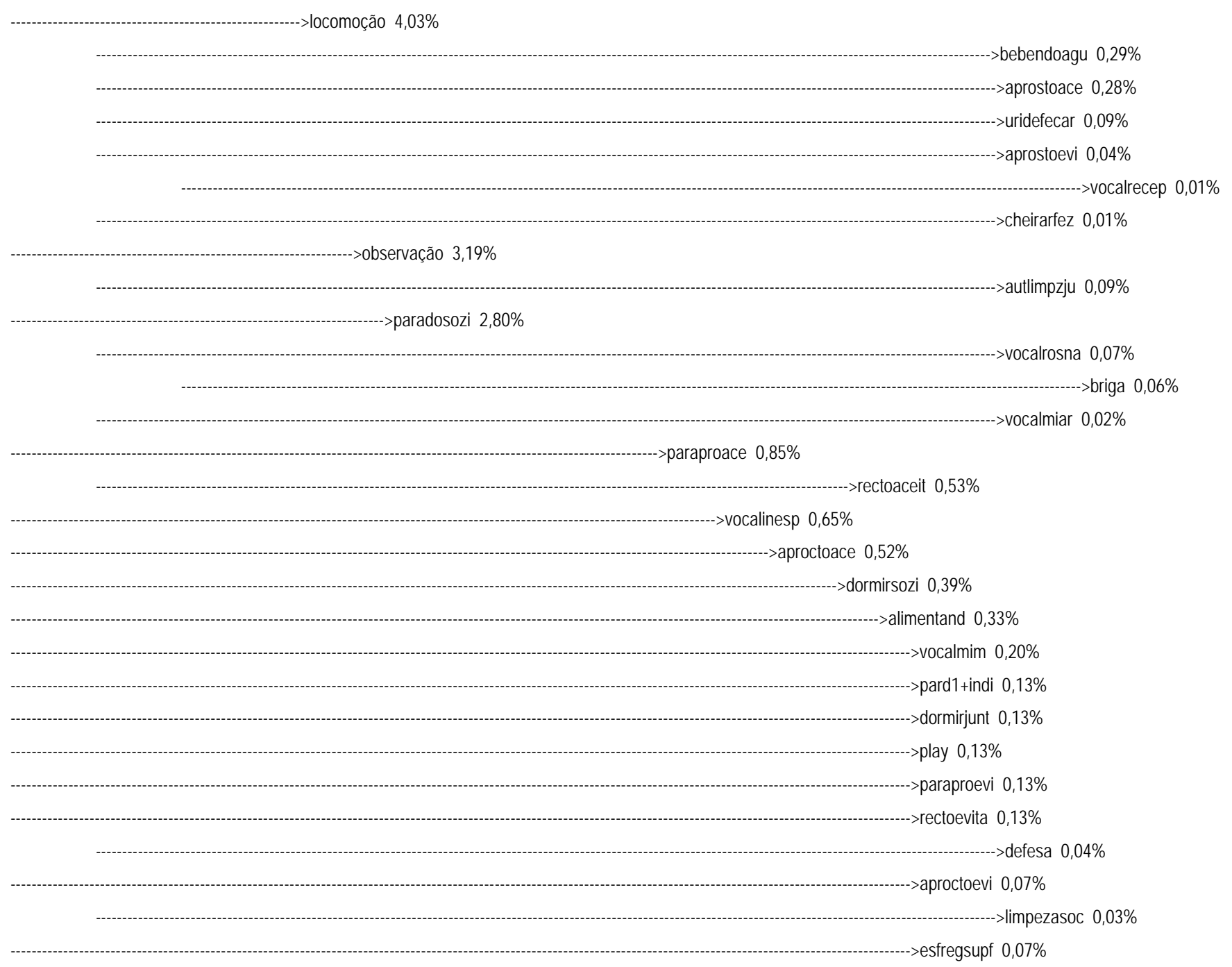

Figura 5.A - Ditree da categoria comportamental “Autolimpeza sozinho” do grupo das fêmeas. 
autlimpzso

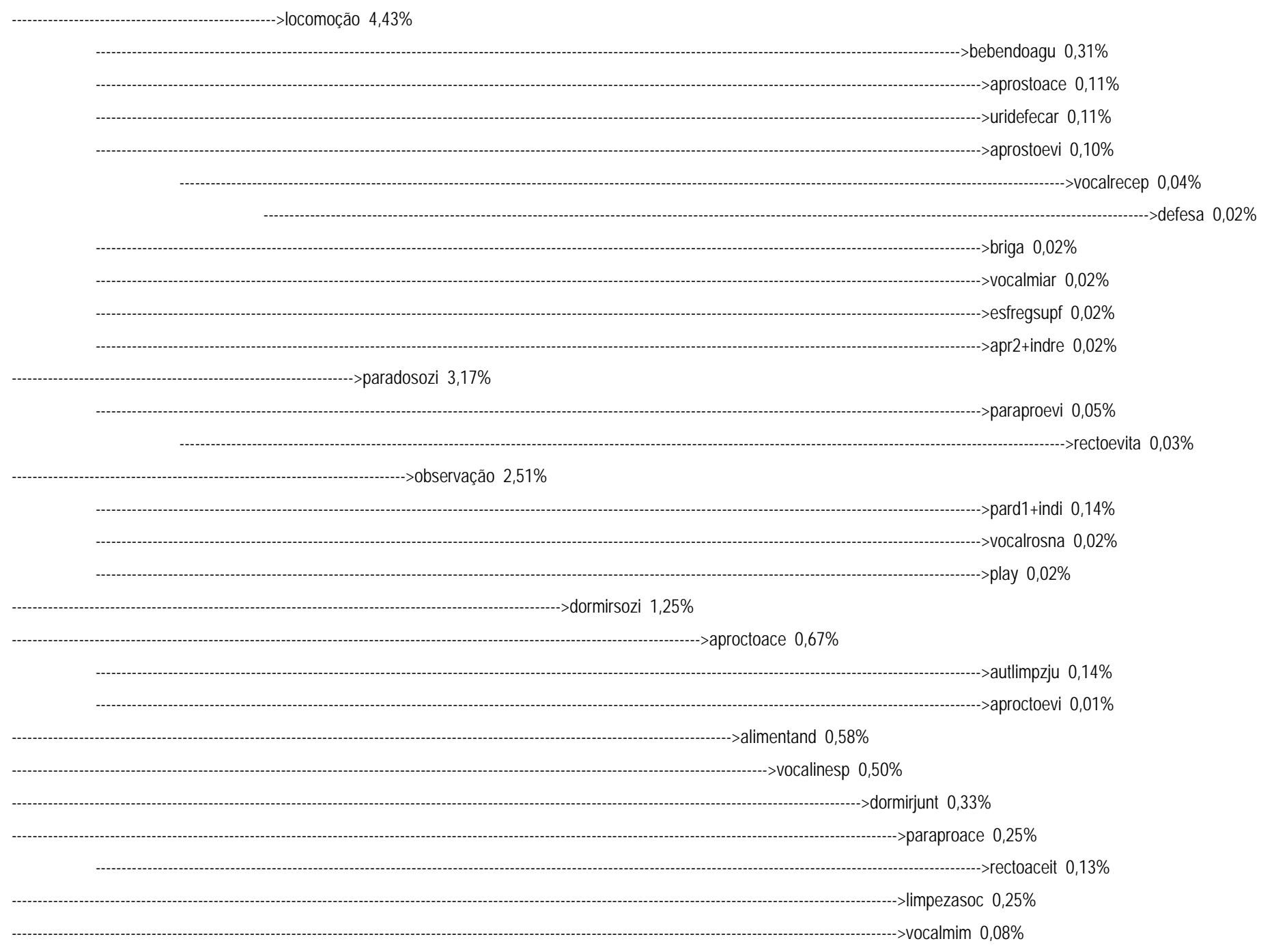

Figura 5.B - Ditree da categoria comportamental “Autolimpeza sozinho” do grupo dos machos. 
As figuras 6.A (Fêmeas) e 6.B (Machos) se referem a categoria comportamental “Bebendoagu” (Beber água). As fêmeas apresentaram a seguinte díade \{locomoção $(0,91)$ - autlimpzso $(0,46)$ \} assim como os machos \{locomoção $(1,00)$ - autlimpzso $(0,33)\}$. Não havendo diferença entre ambos em relação às categorias com maior probabilidade de ocorrência. No entanto se olharmos as probabilidades das outras categorias existe diferença seqüencial, mas os valores probabilísticos são insignificantes.

As figuras 7.A (Fêmeas) e 7.B (Machos) se referem a categoria comportamental “Briga” (Briga). Ambos fêmeas e machos são distintos na seqüência comportamental, no entanto os valores probabilísticos não são significantes, exceto as fêmeas, as quais mostram o comportamento paradosozi $(0,52)$ depois da categoria raiz. Os comportamentos em seguida são locomoção $(0,33)$ e vocalrosna $(0,20)$. Enquanto que os machos mostram a seguinte seqüência (valores não significantes) depois da categoria raiz \{autlimpzso $(0,17)$, paradosozi $(0,17)$ e defesa $(0,17)$. Apesar dos valores probabilísticos mostrarem-se não significantes, é observada a diferença entre os sexos.

As figuras 8.A (Fêmeas) e 8.B (Machos) se referem a categoria comportamental “Defesa” (Defesa). Novamente ambos fêmeas e machos são distintos na seqüência comportamental com os valores probabilísticos não significantes. As fêmeas mostram a seguinte díade (valores não significantes) depois da categoria raiz \{locomoção $(0,26)$, briga $(0,07)\}$, enquanto que os machos \{locomoção $(0,42)$, paradosozi $(0,17)\}$. Apesar dos valores probabilísticos mostrarem-se não significantes, é observada a diferença entre os sexos. 
bebendoagu

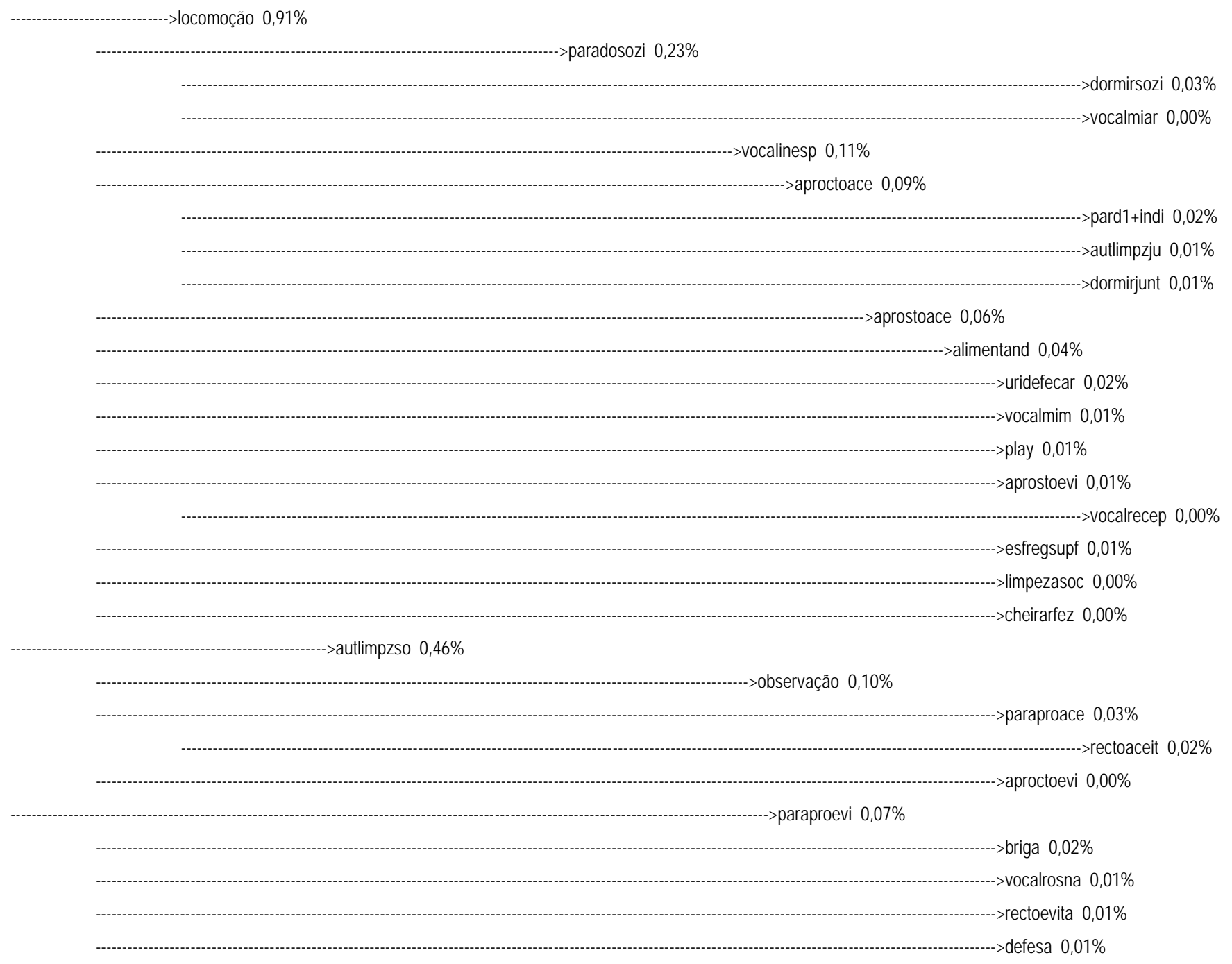

Figura 6.A - Ditree da categoria comportamental “Beber água” do grupo das fêmeas. 
bebendoagu

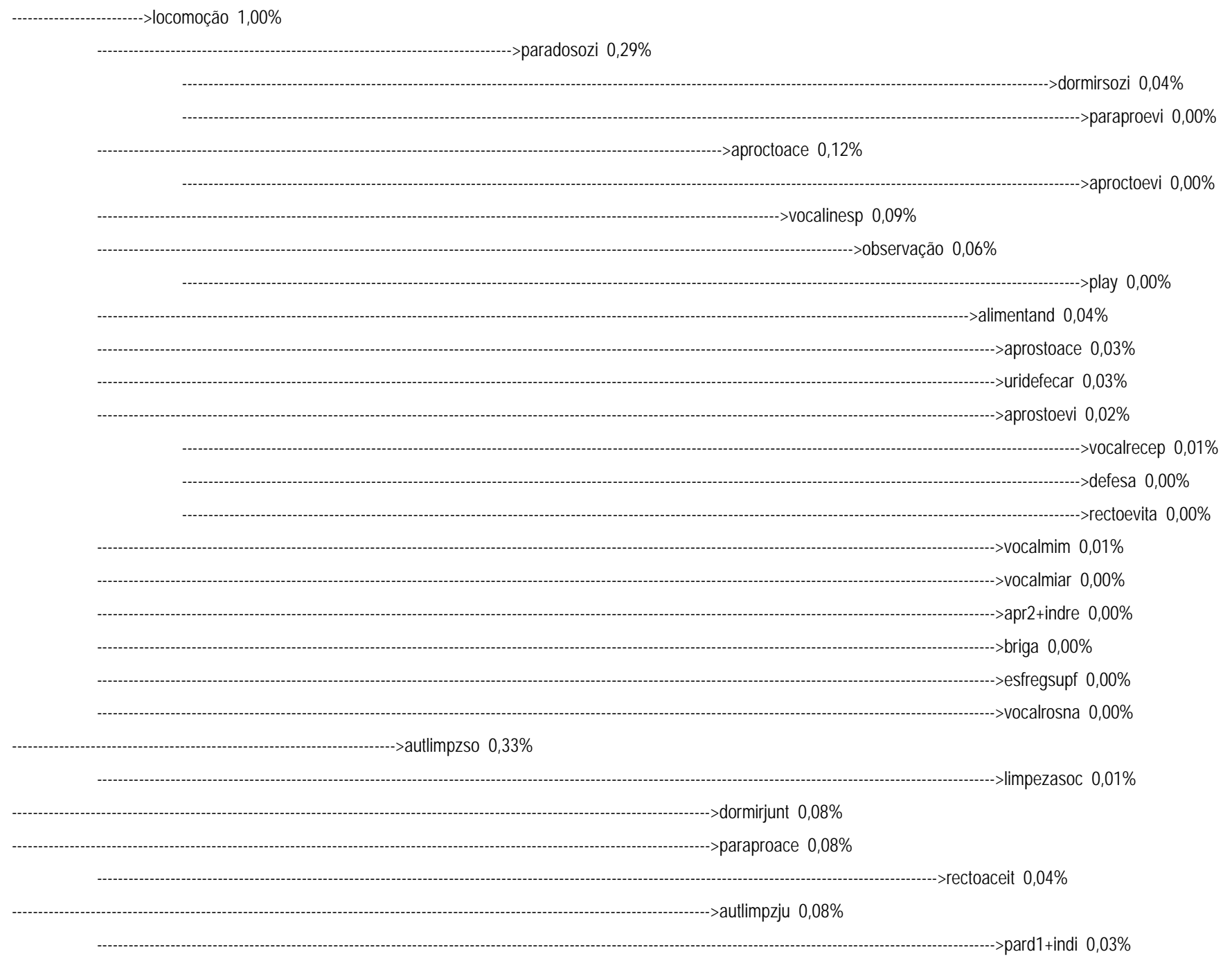

Figura 6.B - Ditree da categoria comportamental “Beber água” do grupo dos machos. 
briga

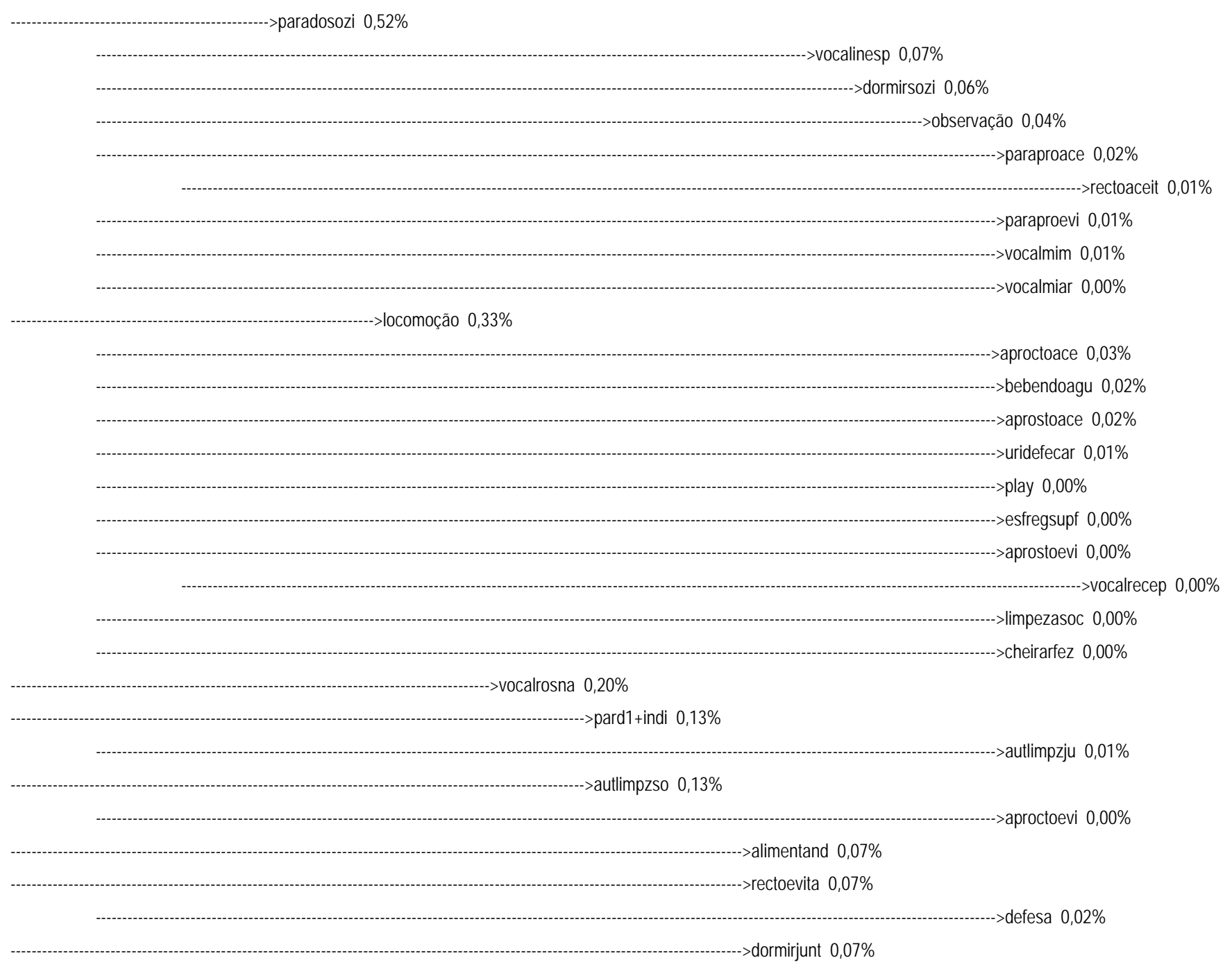

Figura 7.A - Ditree da categoria comportamental "Briga” do grupo das fêmeas. 
briga

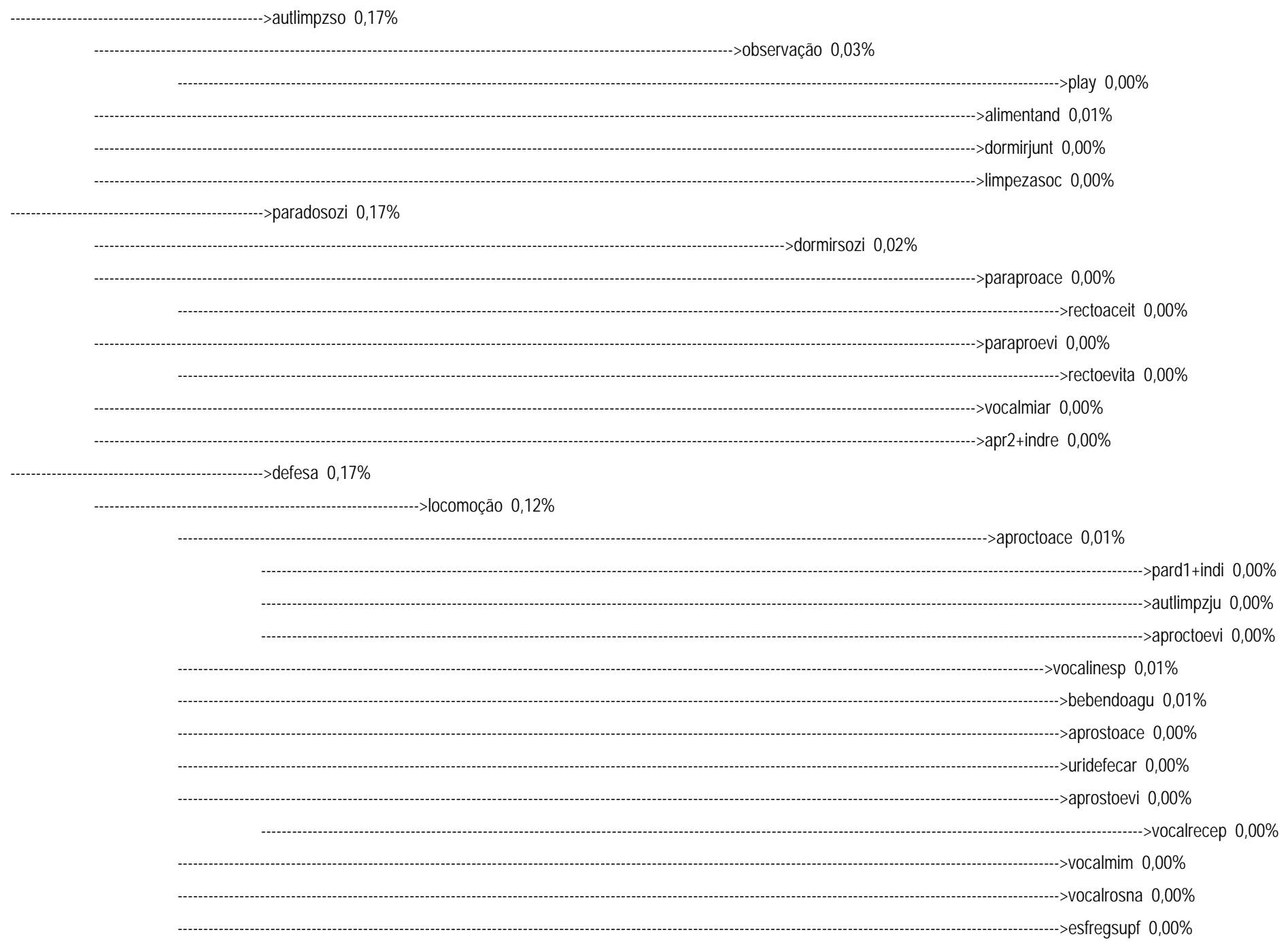

Figura 7.B - Ditree da categoria comportamental “Briga” do grupo dos machos. 
defesa

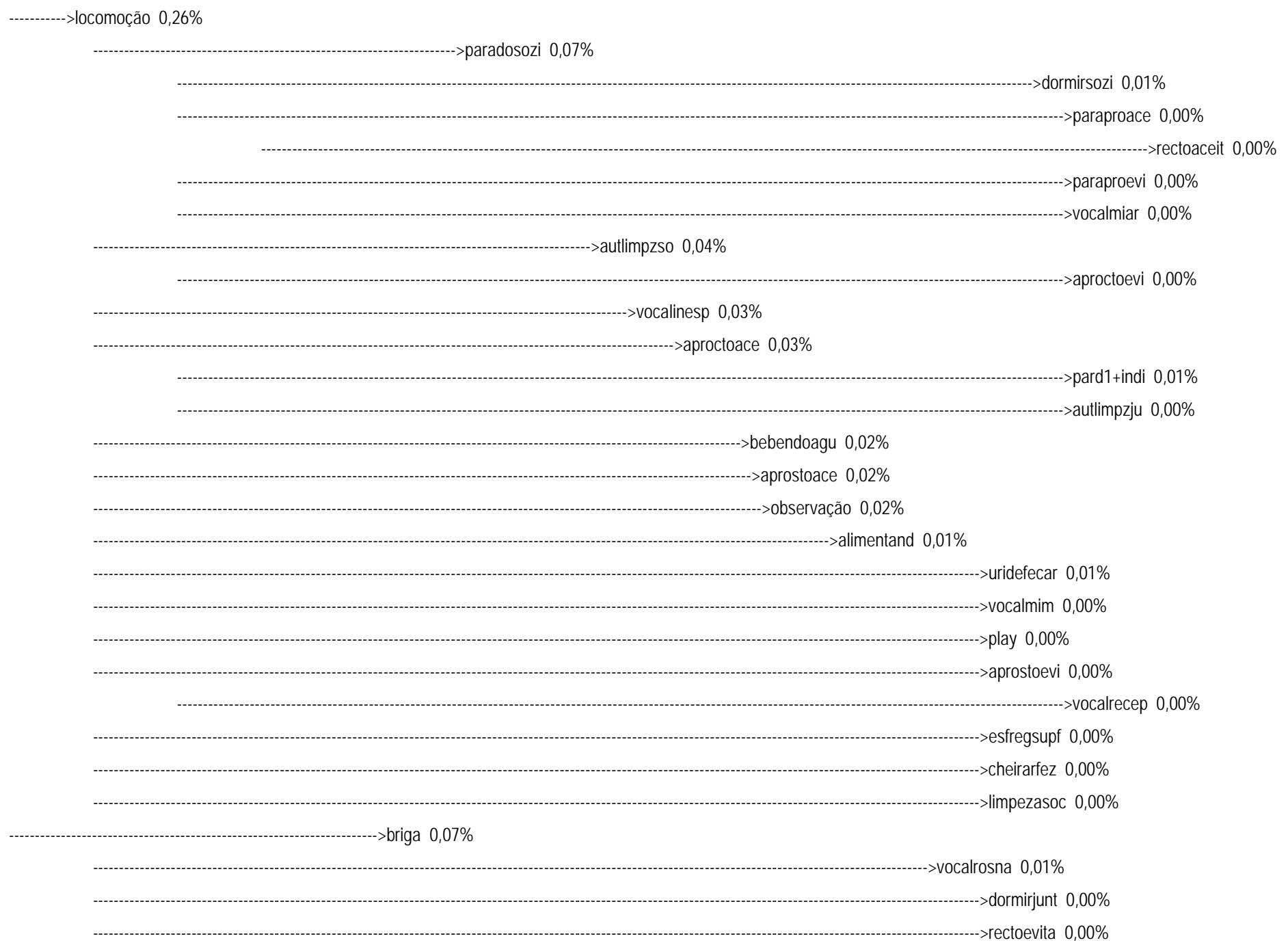

Figura 8.A - Ditree da categoria comportamental “Defesa” do grupo das fêmeas. 
defesa

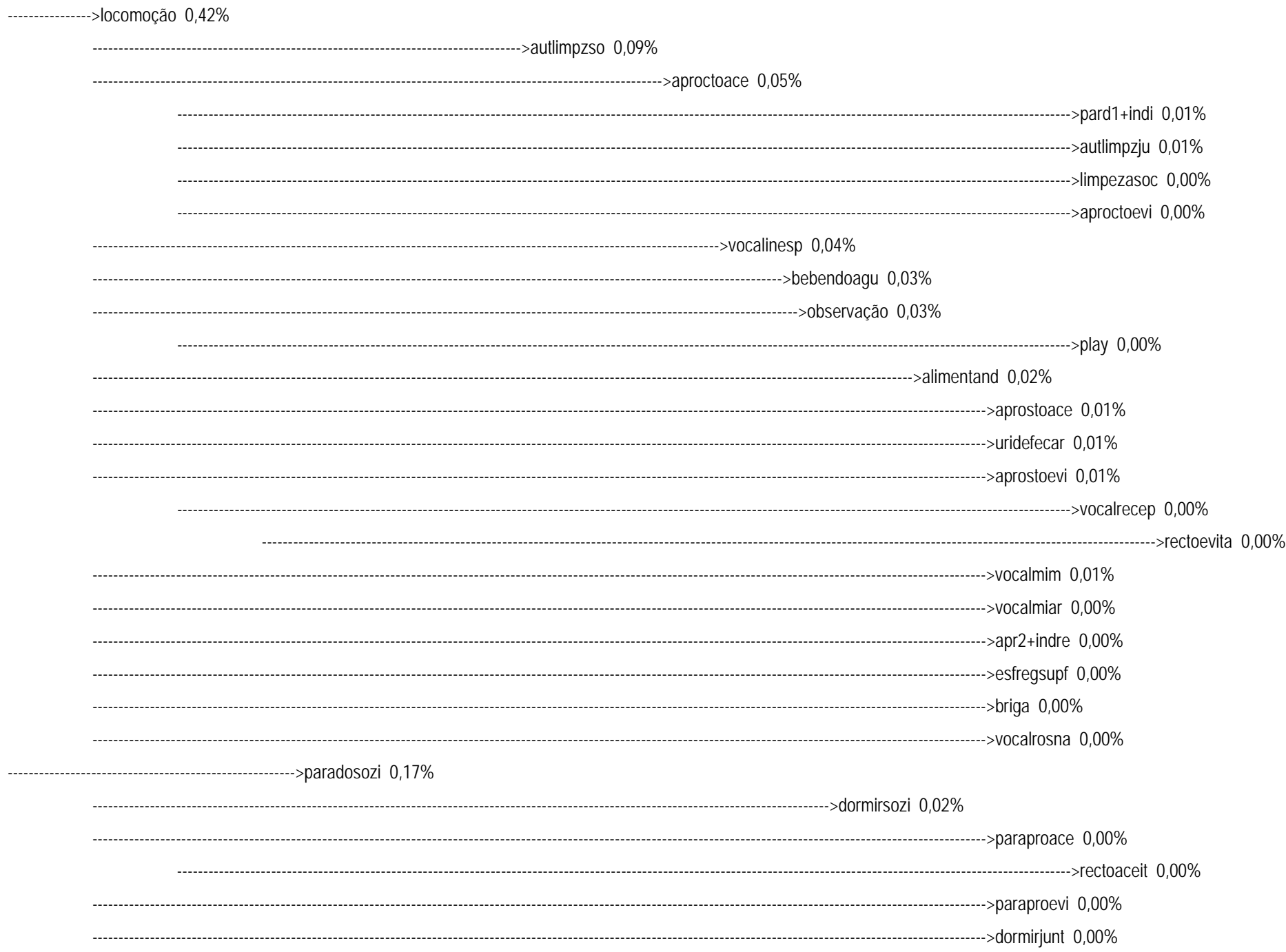

Figura 8.B - Ditree da categoria comportamental "Defesa” do grupo dos machos. 
As figuras 9.A (Fêmeas) e 9.B (Machos) se referem a categoria comportamental "Dormirjunt” (Dormir encostado em outros indivíduos). As fêmeas apresentam a seguinte seqüência depois da categoria raiz \{pard1+indi $(0,65)$ - dormirsozi $(0,59)$, autlimpzso $(0,39)\}$, enquanto que os machos apresentam \{pard1+indi $(0,75)$, autlimpzju $(0,67)$, dormirsozi $(0,50)\}$. Assim sendo percebe-se diferenças nas seqüências comportamentais de ambos os sexos a partir desta categoria raiz, sendo que há diferenças probabilisticamente não significantes também.

As figuras 10.A (Fêmeas) e 10.B (Machos) se referem a categoria comportamental "Dormirsozi” (Dormir sozinho). As fêmeas apresentam a seguinte seqüência depois da categoria raiz \{autlimpzso $(1,04)$, observação $(0,72)$, paraproace $(0,65)$ - rectoaceit $(0,41)$, paradosozi $(0,65)$, locomoção $(0,52)\}$. Enquanto que os machos apresentam a seguinte seqüência \{observação $(2,26)$, autlimpzso $(1,42)$, paradosozi $(1,09)$, locomoção $(0,67)$, paraproace $(0,58)$ - rectoaceit $(0,31)\}$. Apesar de ambos mostrarem as mesmas categorias comportamentais depois da categoria raiz, as seqüências probabilísticas tanto dos machos como das fêmeas diferem.

As figuras 11.A (Fêmeas) e 11.B (Machos) se referem a categoria comportamental "Locomoção" (Locomoção). As fêmeas apresentam a seguinte seqüência depois da categoria raiz \{paradosozi $(5,14)$, dormirsozi $(0,57)$, autlimpzso $(2,80)$, vocalinesp $(2,41)$, aproctoace $(1,95)$, bebendoagu $(1,43)$, aprostoace $(1,37)$, observação $(1,30)$, alimentand $(0,98)\}$. Enquanto que os machos apresentam a seguinte seqüência \{paradosozi $(5,60)$, autlimpzso $(4,18)$, aproctoace $(2,26)$, vocalinesp $(1,75)$, bebendoagu $(1,34)$, observação $(1,25)$, alimentand $(0,75)\}$. Apesar de ambos mostrarem algumas categorias comportamentais iguais depois da categoria raiz, as seqüências probabilísticas tanto dos machos como das fêmeas diferem. 
dormirjunt

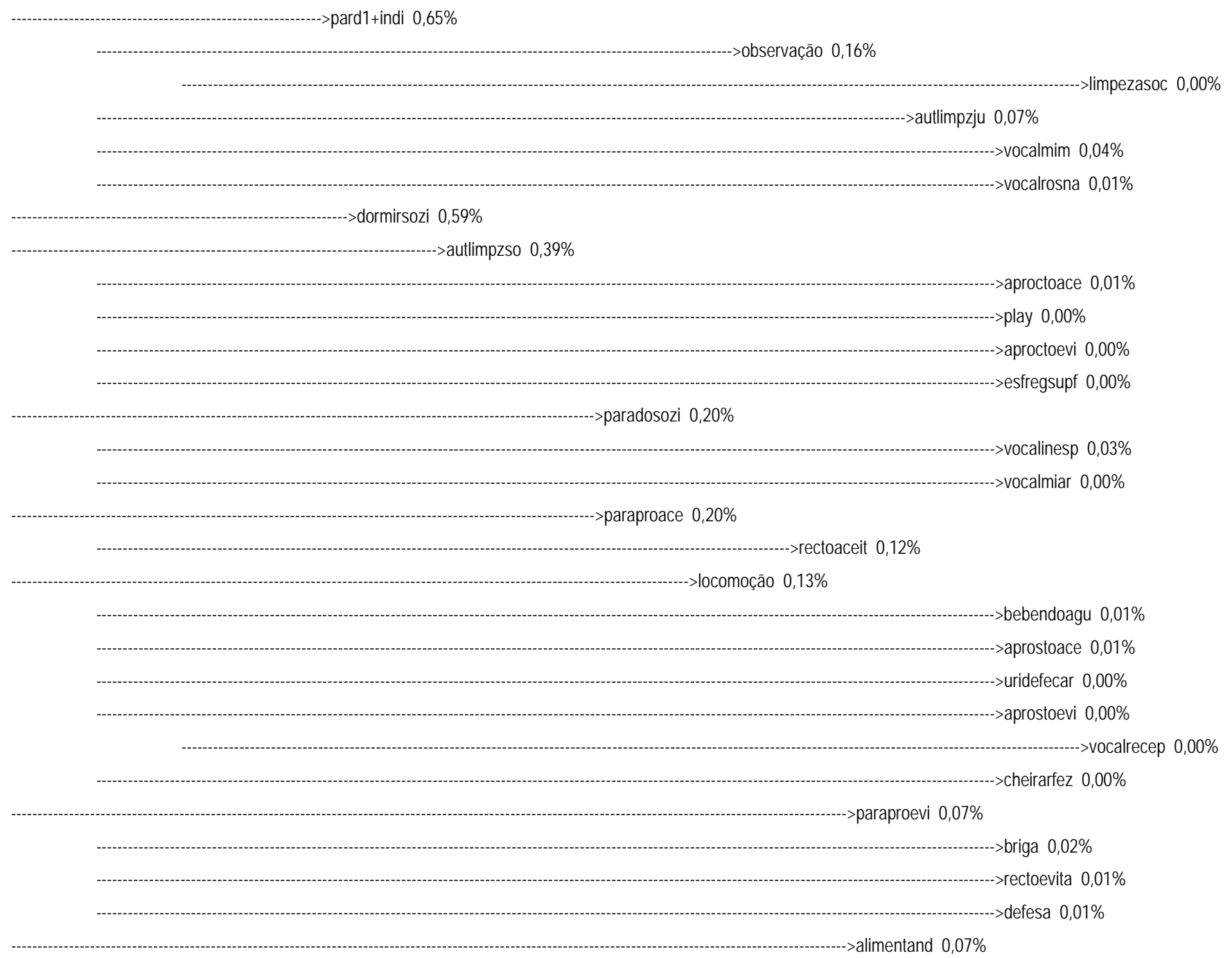

Figura 9.A - Ditree da categoria comportamental “Dormir encostado em outros animais” do grupo das fêmeas. 


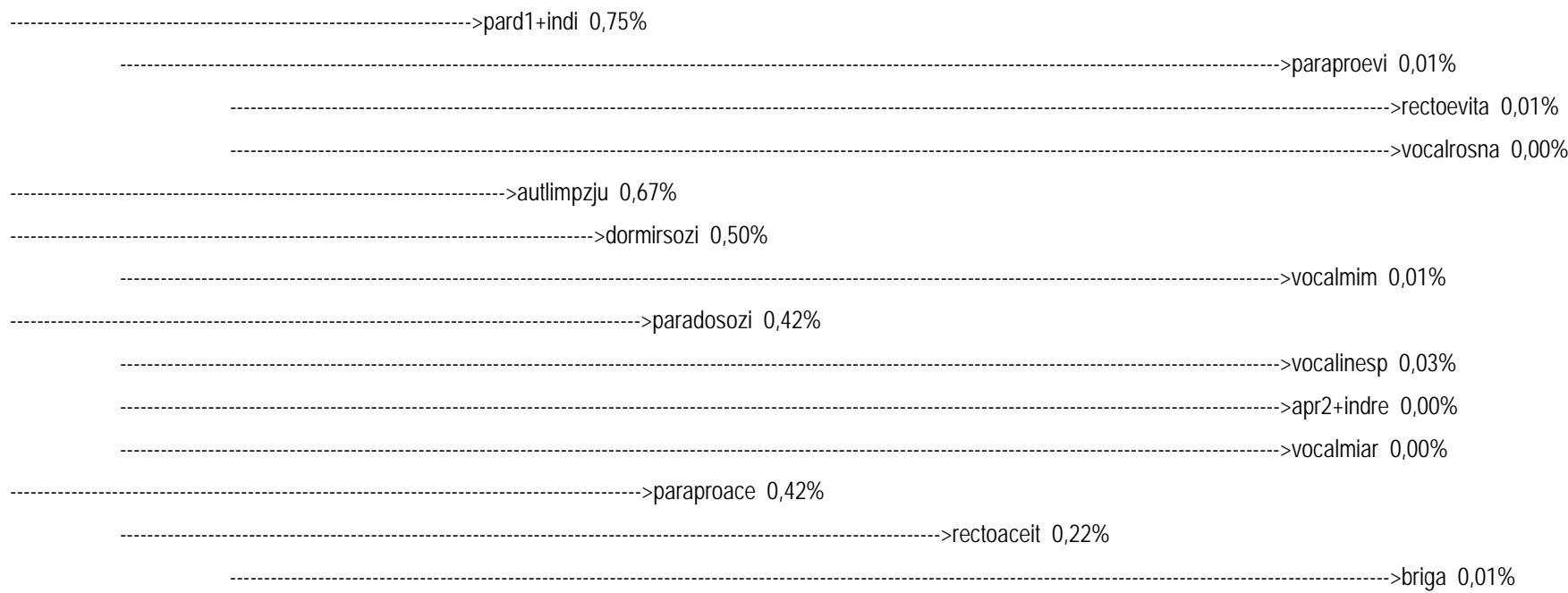

--->defesa $0,00 \%$

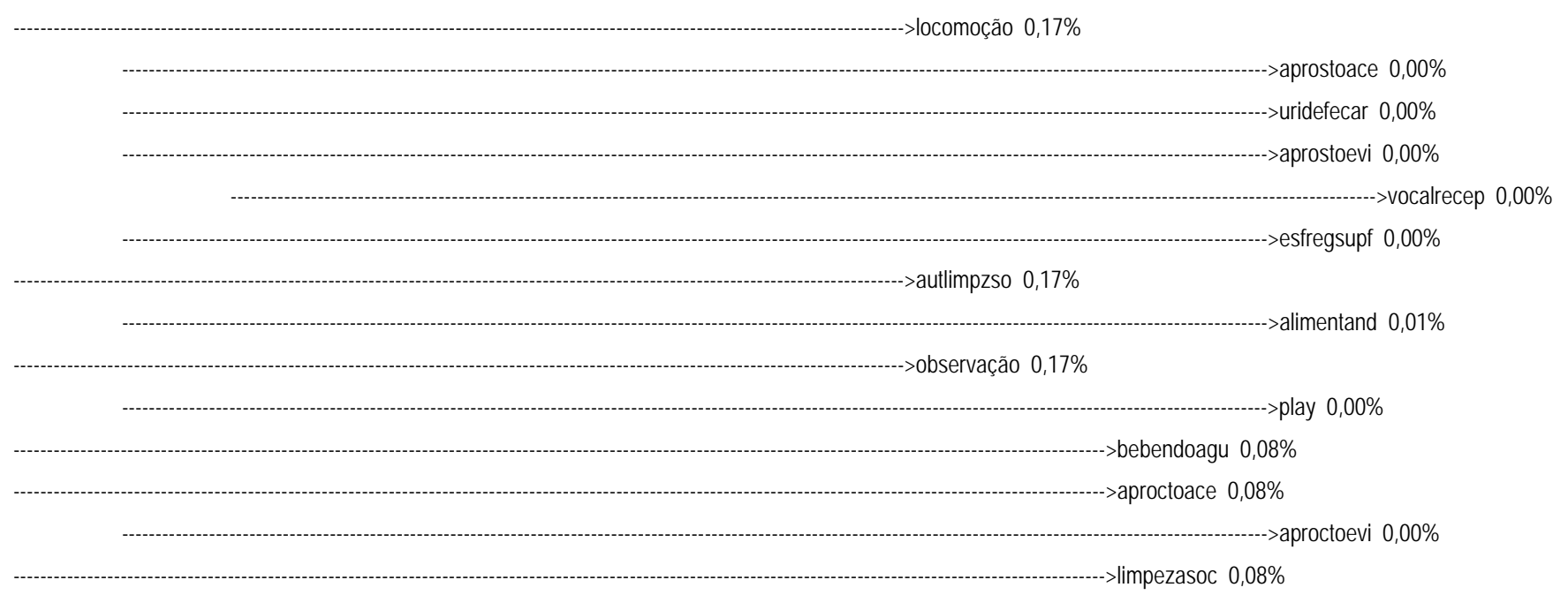

Figura 9.B - Ditree da categoria comportamental “Dormir encostado em outros animais” do grupo dos machos. 
dormirsozi

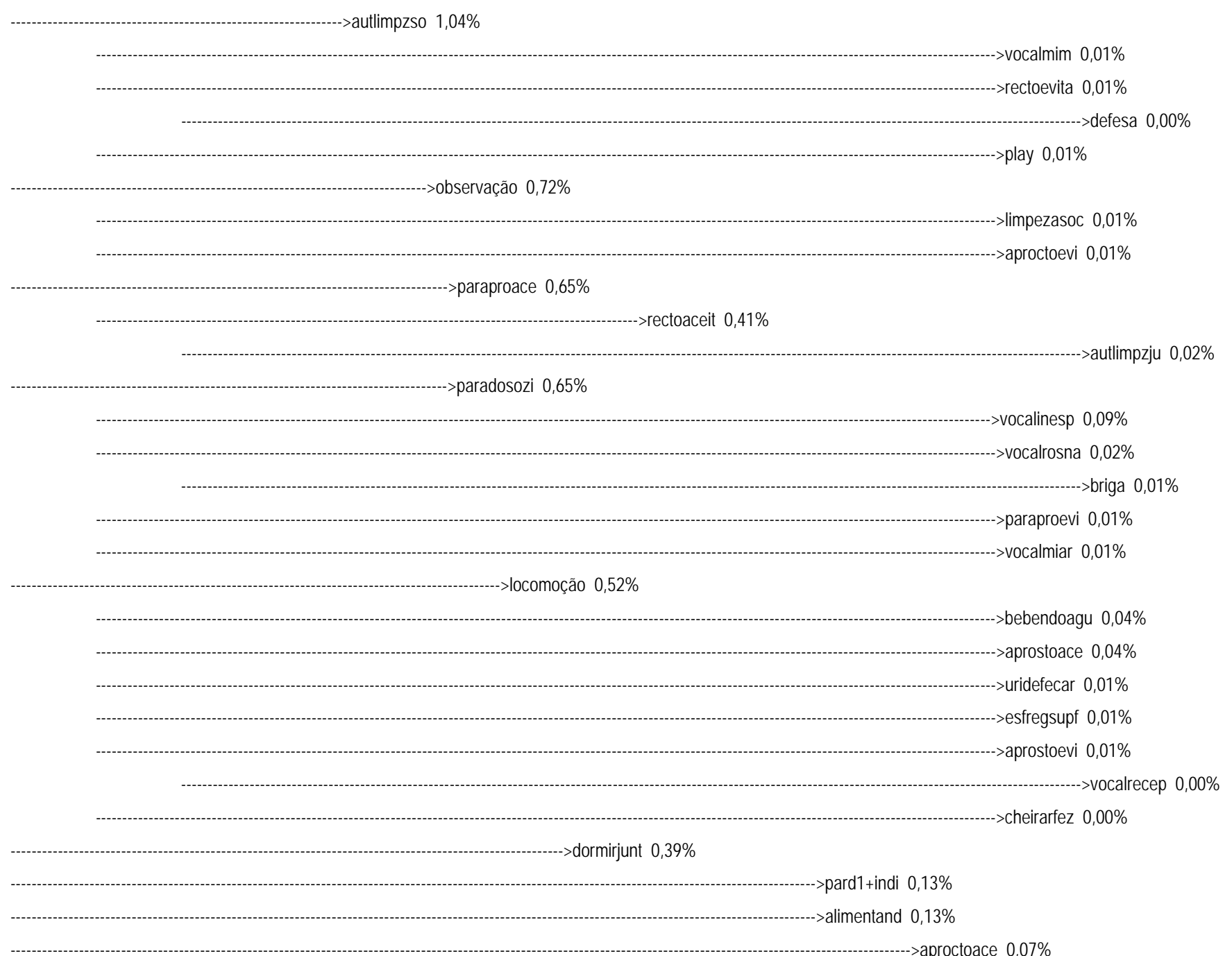

Figura 10.A - Ditree da categoria comportamental “Dormir sozinho” do grupo das fêmeas. 
dormirsozi

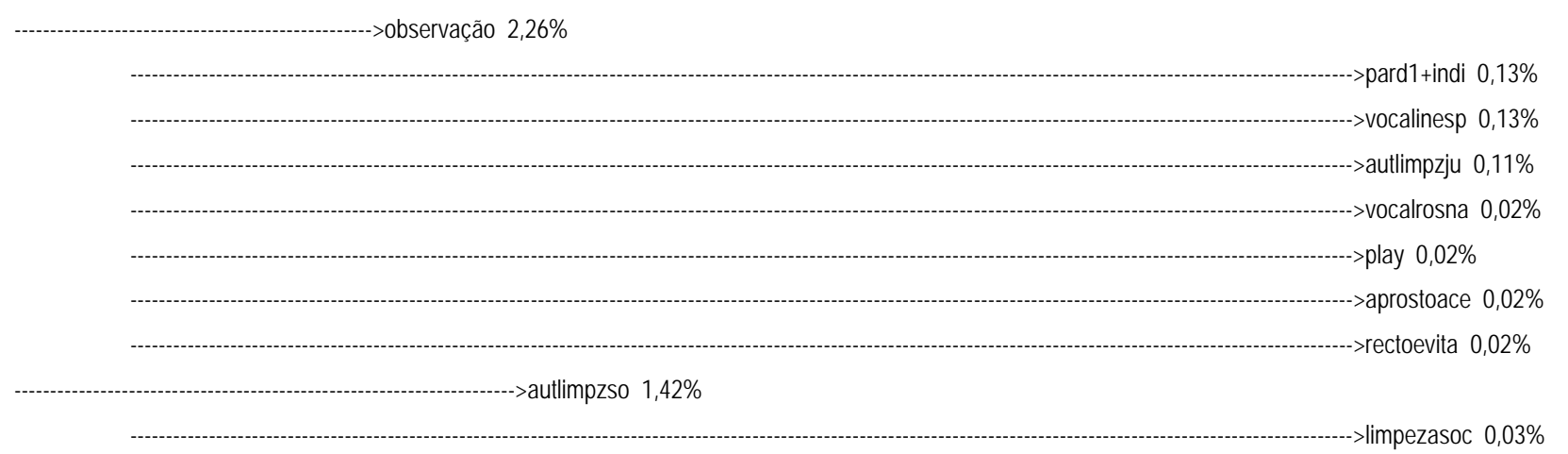

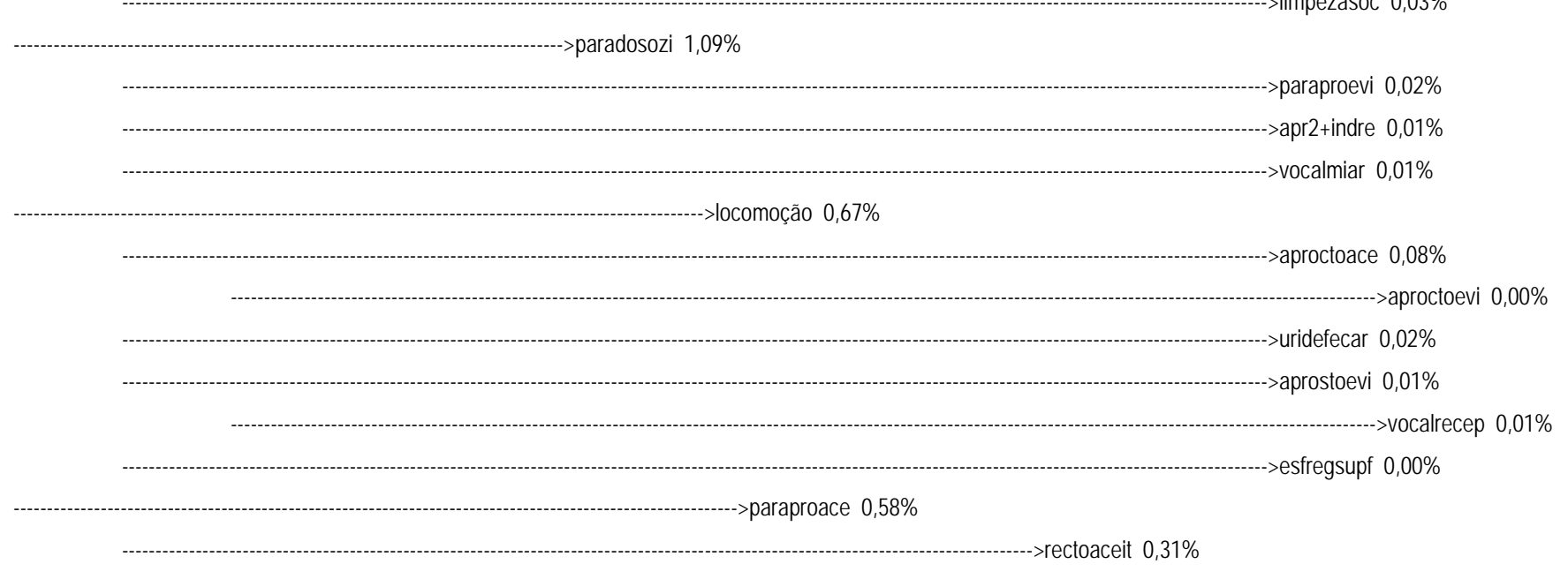
$>$ briga $0,02 \%$

-

Figura 10.B - Ditree da categoria comportamental “Dormir sozinho” do grupo dos machos. 


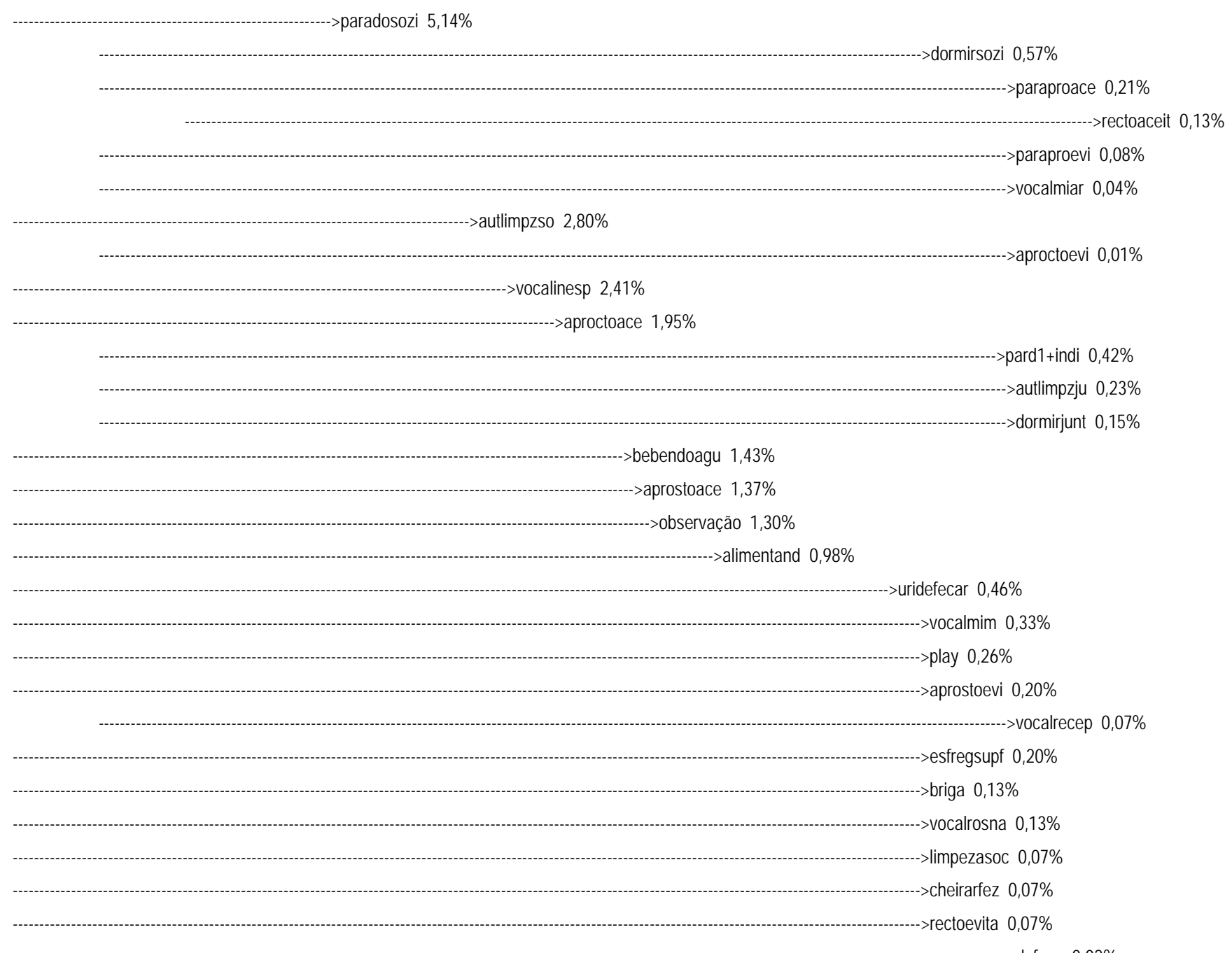

Figura 11.A - Ditree da categoria comportamental “Locomoção” do grupo das fêmeas. 


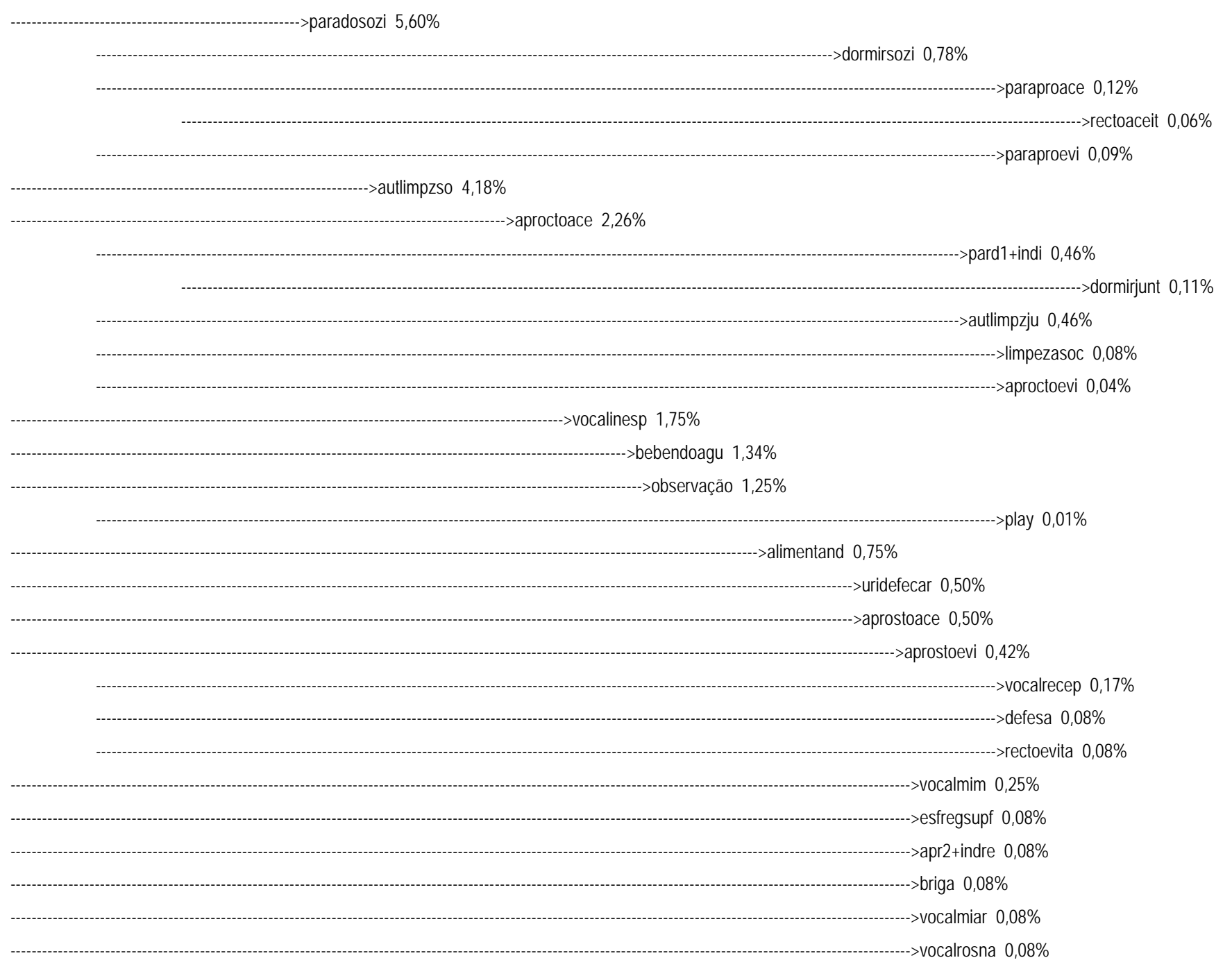

Figura 11.B - Ditree da categoria comportamental “Locomoção” do grupo dos machos. 
As figuras 12.A (Fêmeas) e 12.B (Machos) se referem a categoria comportamental "Observação” (Observação). As fêmeas apresentam a seguinte seqüência depois da categoria raiz \{autlimpzso $(4,18)$, locomoção $(2,34)$, paradosozi $(1,37)$, vocalinesp $(0,52)$, dormirsozi $(0,52)$, os machos apresentaram \{autlimpzso $(2,42)$, locomoção $(1,59)$, paradosozi $(1,50)$, dormirsozi $(1,50)$, vocalinesp $(0,58)$, pard1+ind $(0,58)$, autlimpzju $(0,50)\}$. Os machos e as fêmeas mostram uma tríade de probabilidade significante inicial semelhante, mas depois as diferenças são perceptíveis.

As figuras 13.A (Fêmeas) e 13.B (Machos) se referem a categoria comportamental "Paradosozi" (Parado sozinho). As fêmeas apresentam a seguinte seqüência depois da categoria raiz \{locomoção $(4,03)$, autlimpzso $(3,64)$, vocalinesp $(2,15)$, dormirsozi $(1,76)$, observação $(1,30)$, paraproace $(0,65)\}$. Enquanto que os machos apresentam a seguinte seqüência \{locomoção $(5,01)$, autlimpzso $(3,68)$, dormirsozi $(2,17)$, observação $(1,34)$, vocalinesp $(1,00)$, paraproace $(0,33)\}$. Ambos apresentam a primeira díade semelhante e a seguinte com os mesmos comportamentos mas na ordem seqüencial trocada. Apesar de ambos mostrarem algumas categorias comportamentais iguais depois da categoria raiz, as seqüências probabilísticas tanto dos machos como das fêmeas diferem, tanto as estatisticamente significantes assim como as não significantes.

As figuras 14.A (Fêmeas) e 14.B (Machos) se referem a categoria comportamental "Paraproace” (Parado e a aprox. de outro animal é aceita). As fêmeas apresentam a seguinte seqüência depois da categoria raiz \{rectoaceit $(2,08)$, paradosozi $(0,48)$, pard1+ind $(0,42)$ \}, já os machos apresentaram \{rectoaceit $(1,25)$, pard1+ind $(0,33)$ locomoção $(0,20)\}$. Os machos e as fêmeas mostram a mesma probabilidade significante inicial, mas depois as diferenças seqüenciais são perceptíveis. 
observação

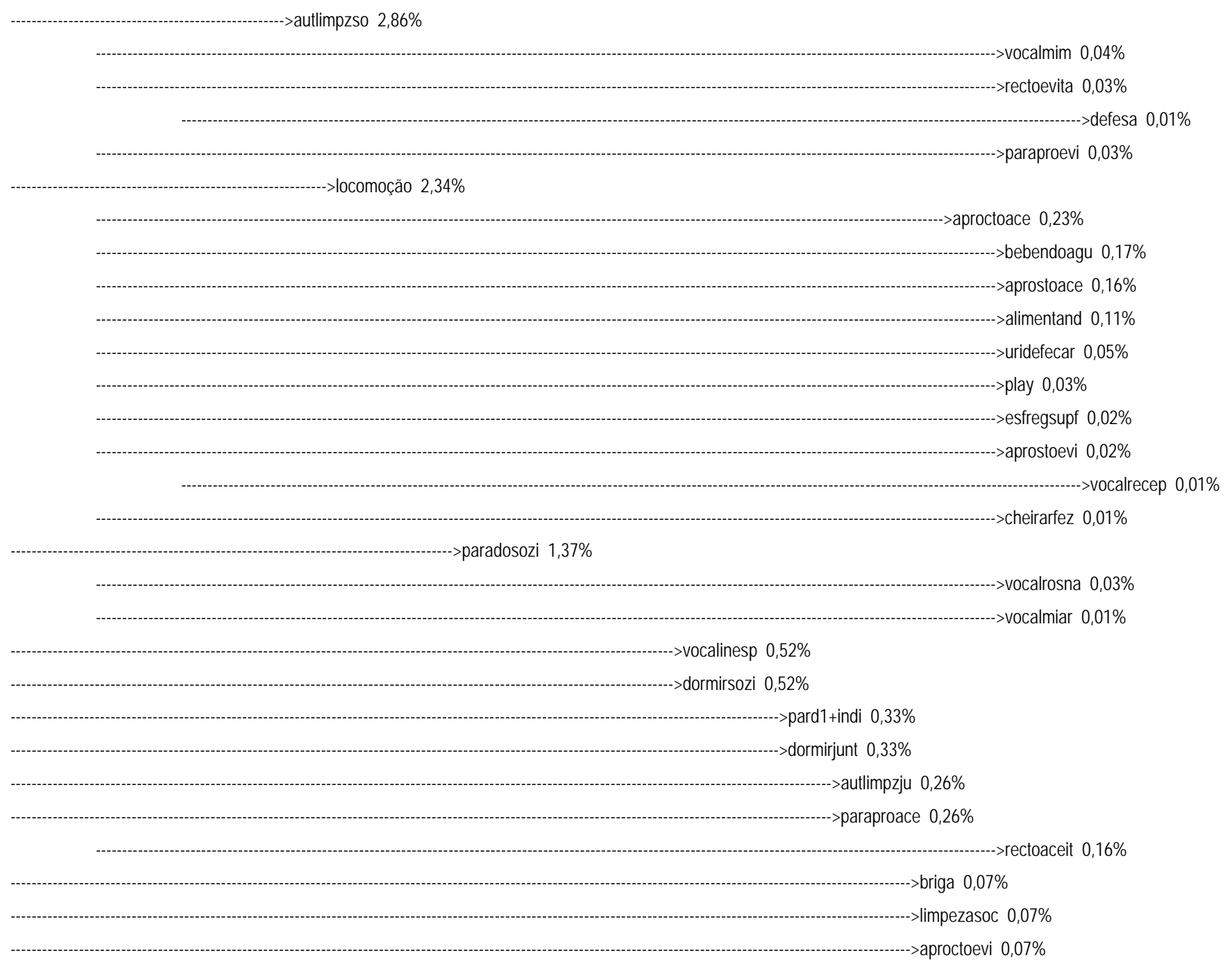

Figura 12.A - Ditree da categoria comportamental “Observação” do grupo das fêmeas. 


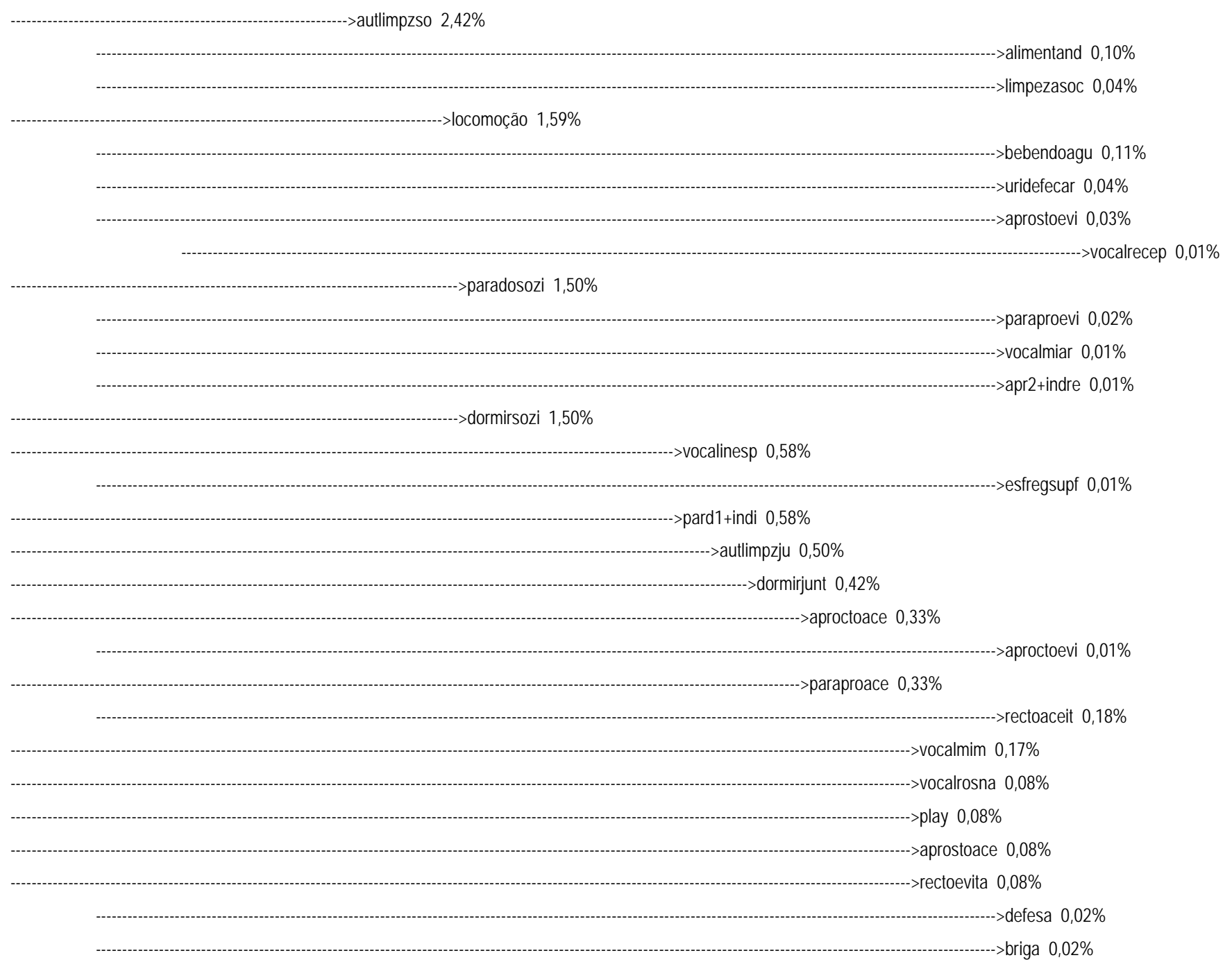

Figura 12.B - Ditree da categoria comportamental “Observação” do grupo dos machos. 
paradosozi

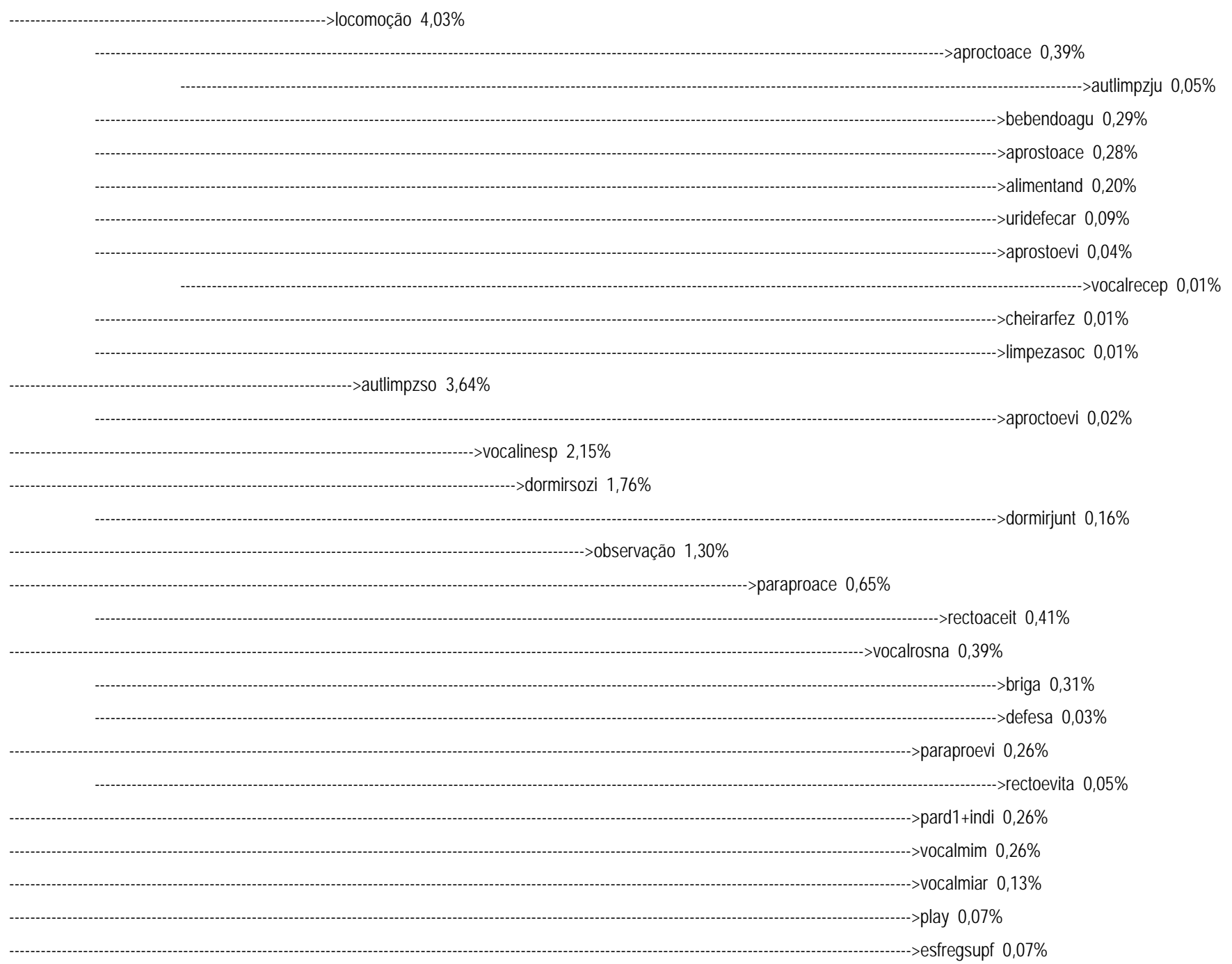

Figura 13.A - Ditree da categoria comportamental “Parado sozinho” do grupo das fêmeas. 
paradosozi

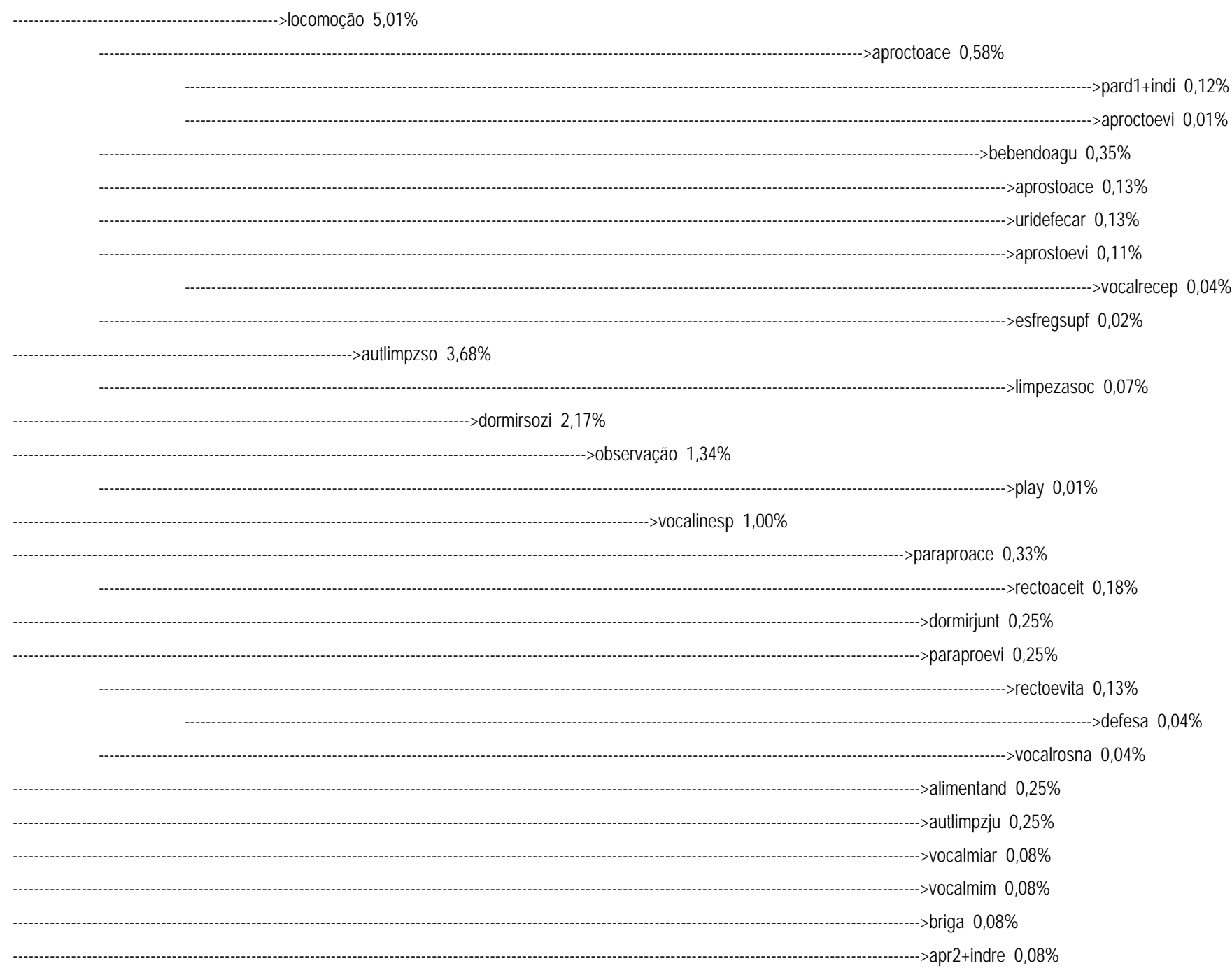

Figura 13.B - Ditree da categoria comportamental "Parado sozinho” do grupo dos machos. 
paraproace

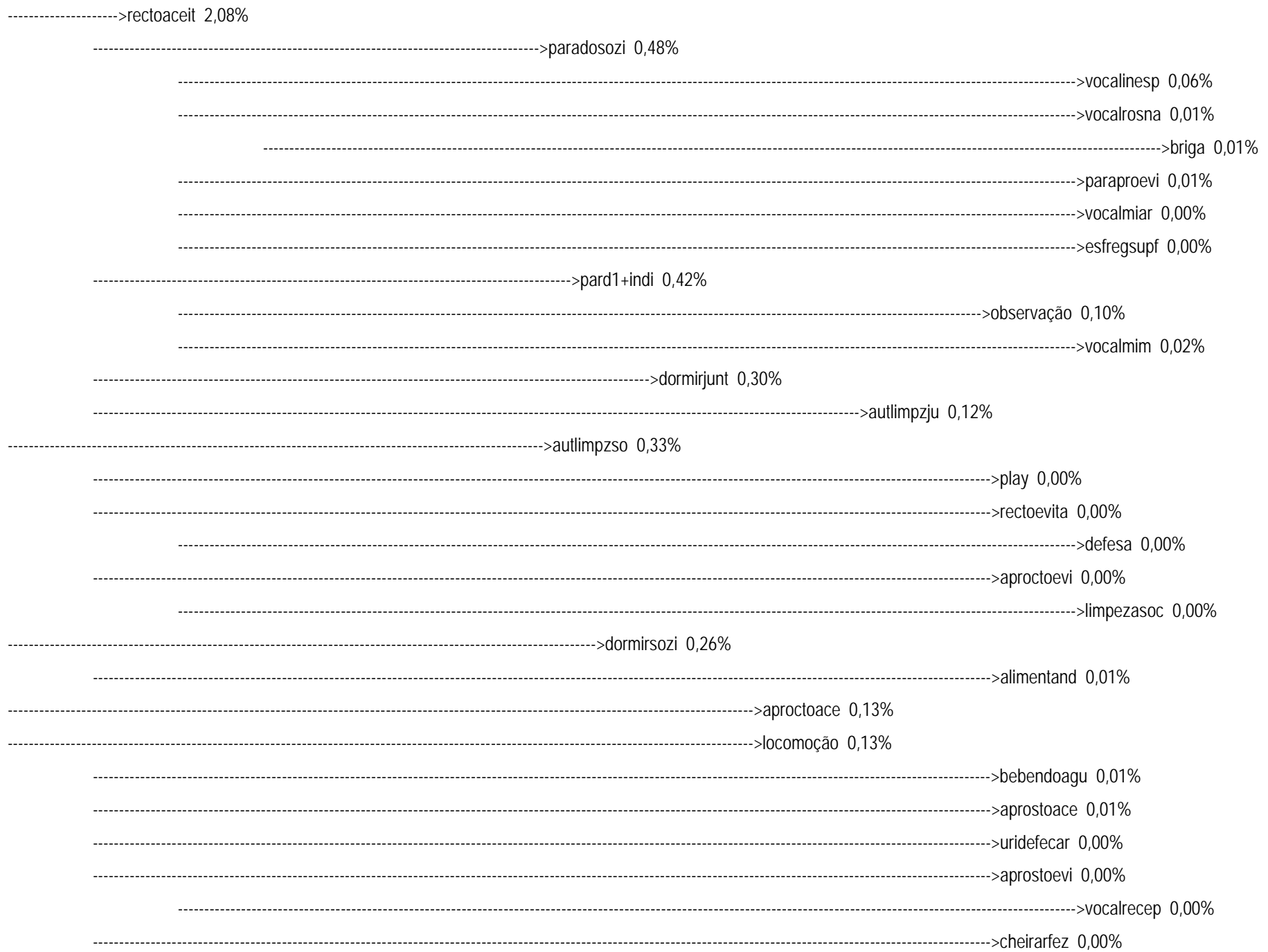

Figura 14.A - Ditree da categoria comportamental “Parado e aproximação de outro animal é aceita” do grupo das fêmeas. 
paraproace

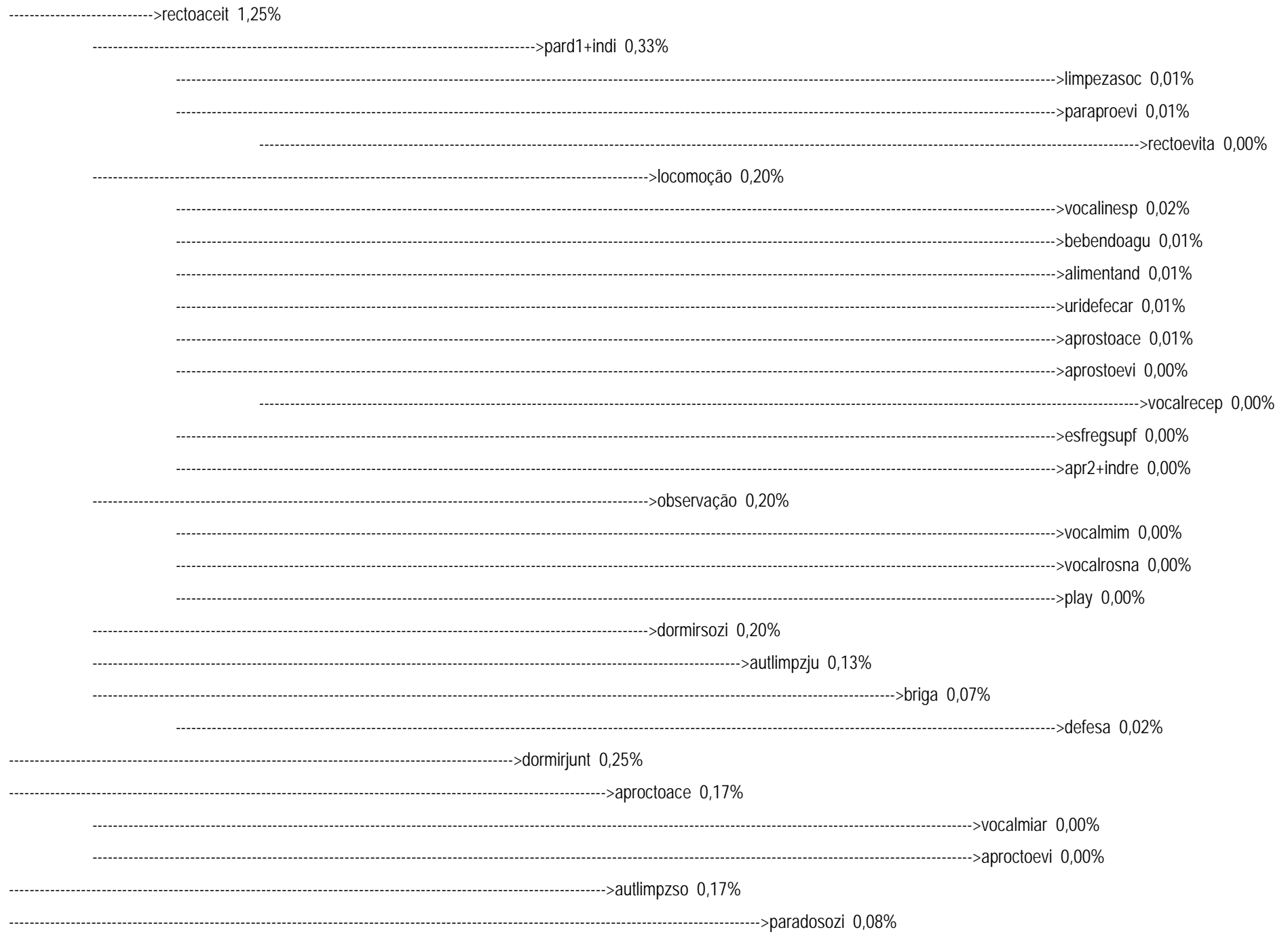

Figura 14.B - Ditree da categoria comportamental "Parado e aproximação de outro animal é aceita” do grupo dos machos. 
As figuras 15.A (Fêmeas) e 15.B (Machos) se referem a categoria comportamental "Paraproevi" (Parado e a aprox. de outro animal é evitada). As fêmeas apresentam a seguinte sequiência depois da categoria raiz \{briga $(0,26)$, vocalrosna $(0,13)$, rectoevita $(0,13)\}$, os machos apresentaram \{rectoevita $(0,25)$ locomoção $(0,08)$, briga $(0,08)$, vocalrosna $(0,08)\}$. Apesar destes valores probabilísticos serem insignificantes nota-se as diferenças de machos e as fêmeas.

As figuras 16.A (Fêmeas) e 16.B (Machos) se referem a categoria comportamental "Pard1+ind" (Parado encostado em 1 ou + animais). As fêmeas apresentam a seguinte seqüência depois da categoria raiz \{observação $(0,85)$, dormirjunt $(0,59)$, paraproace $(0,52)$ - rectoaceit $(0,33)$, autlimpzju $(0,39)\}$, os machos apresentaram \{dormirjunt $(1,09)$, observação $(0,92)$, locomoção $(0,50)$, autlimpzju $(0,42)\}$. Depois da categoria raiz, ambos machos e fêmeas apresentam a primeira díade com os mesmos comportamentos, no entanto na seqüência trocada, além disso as seqüências seguintes também diferem.

As figuras 17.A (Fêmeas) e 17.B (Machos) se referem a categoria comportamental "Rectoaceit" (Receber toque de outro animal e aceitar). As fêmeas apresentam a seguinte seqüência depois da categoria raiz \{paradosozi $(0,52)$, pard1+ind $(0,46)$, autlimpzso(0,33), dormirjunt $(0,33)\}$, os machos apresentaram \{pard1+ind $(0,42)$, observação $(0,25)$, dormirsozi $(0,25)$, locomoção $(0,25)\}$. Apesar de alguns valores probabilísticos não serem significantes nota-se as diferenças de machos e as fêmeas. 
paraproevi

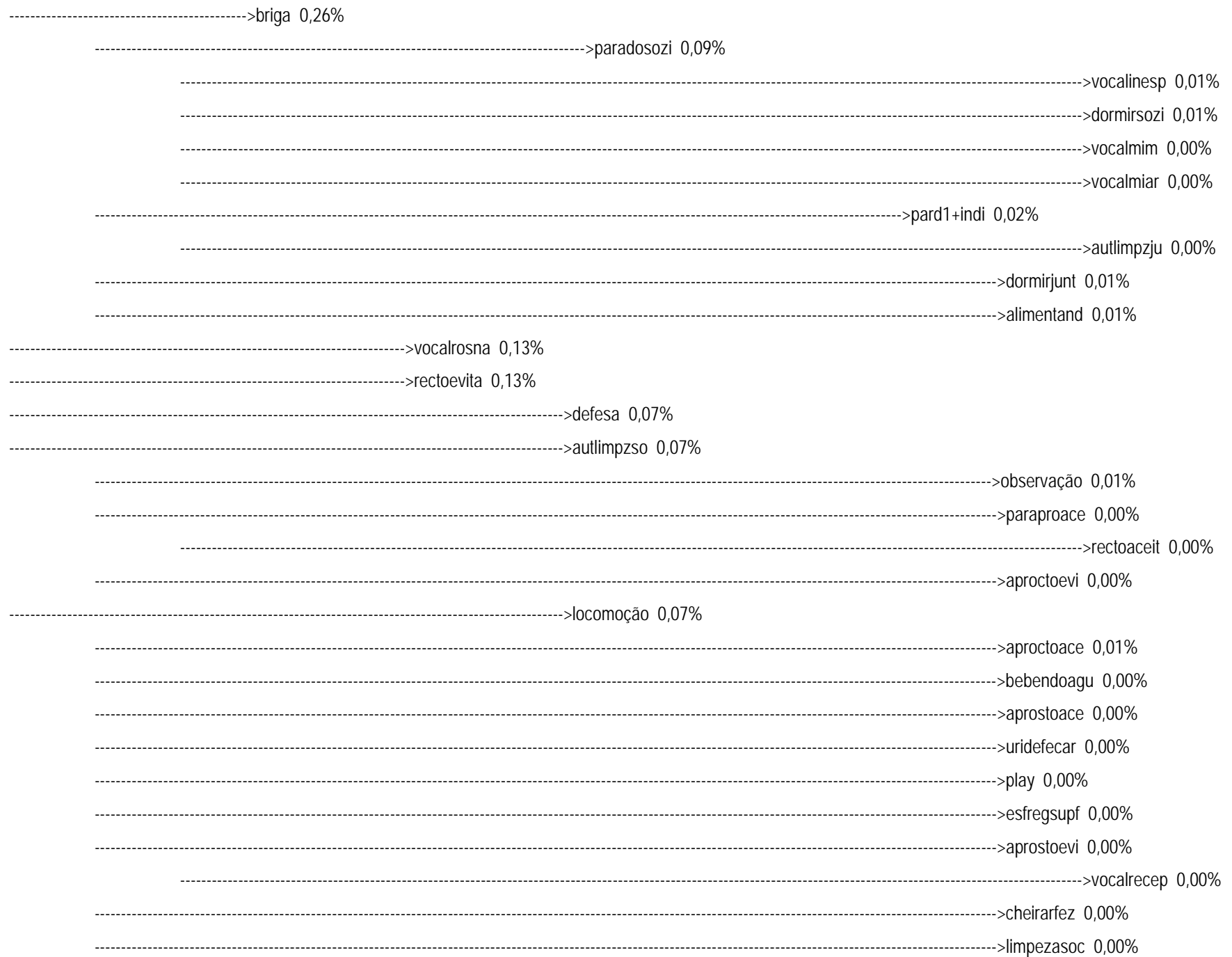

Figura 15.A - Ditree da categoria comportamental “Parado e aproximação de outro animal é evitada” do grupo das fêmeas. 
paraproevi

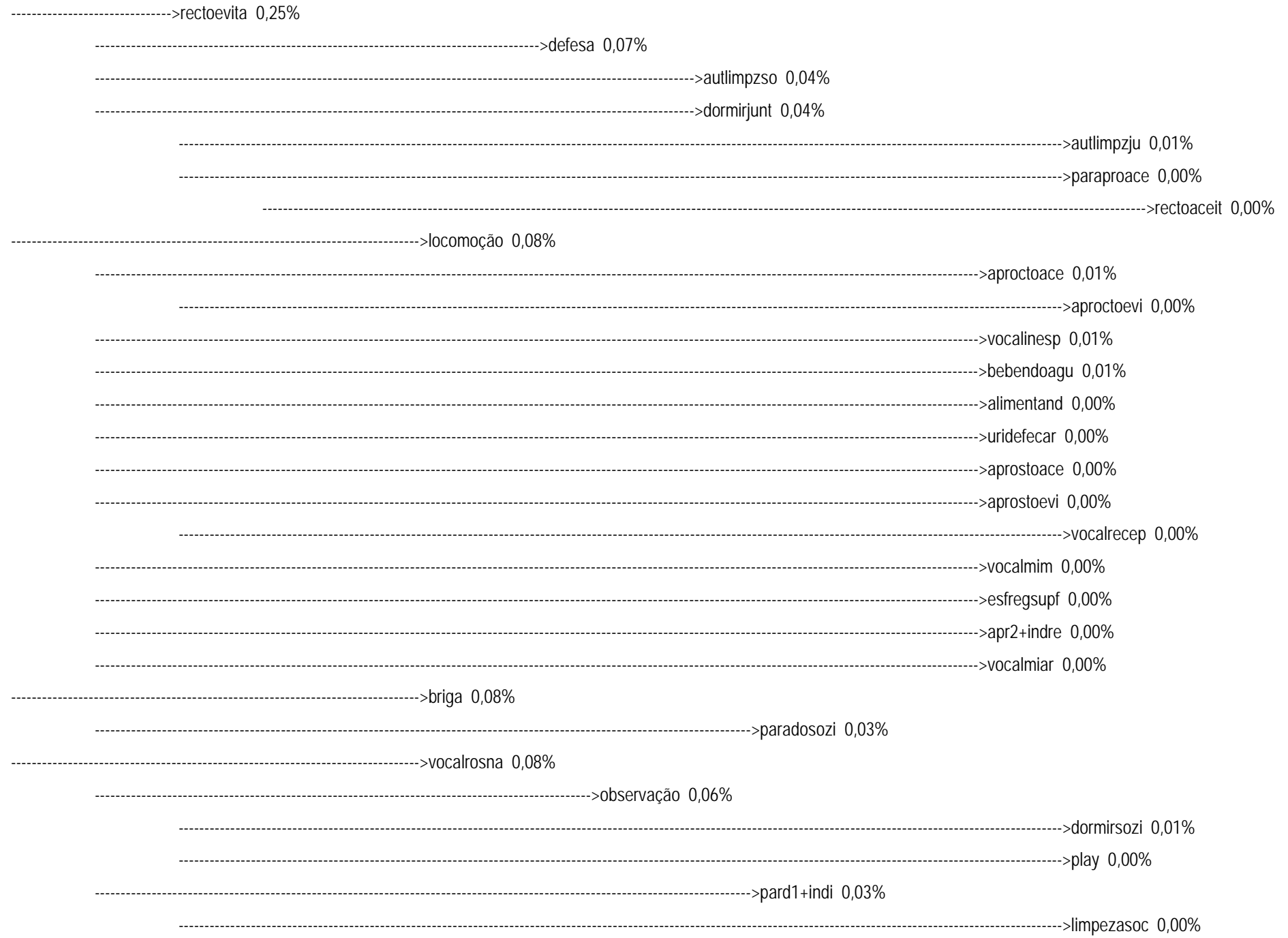

Figura 15.B - Ditree da categoria comportamental "Parado e aproximação de outro animal é evitada” do grupo dos machos. 
pard1+indi

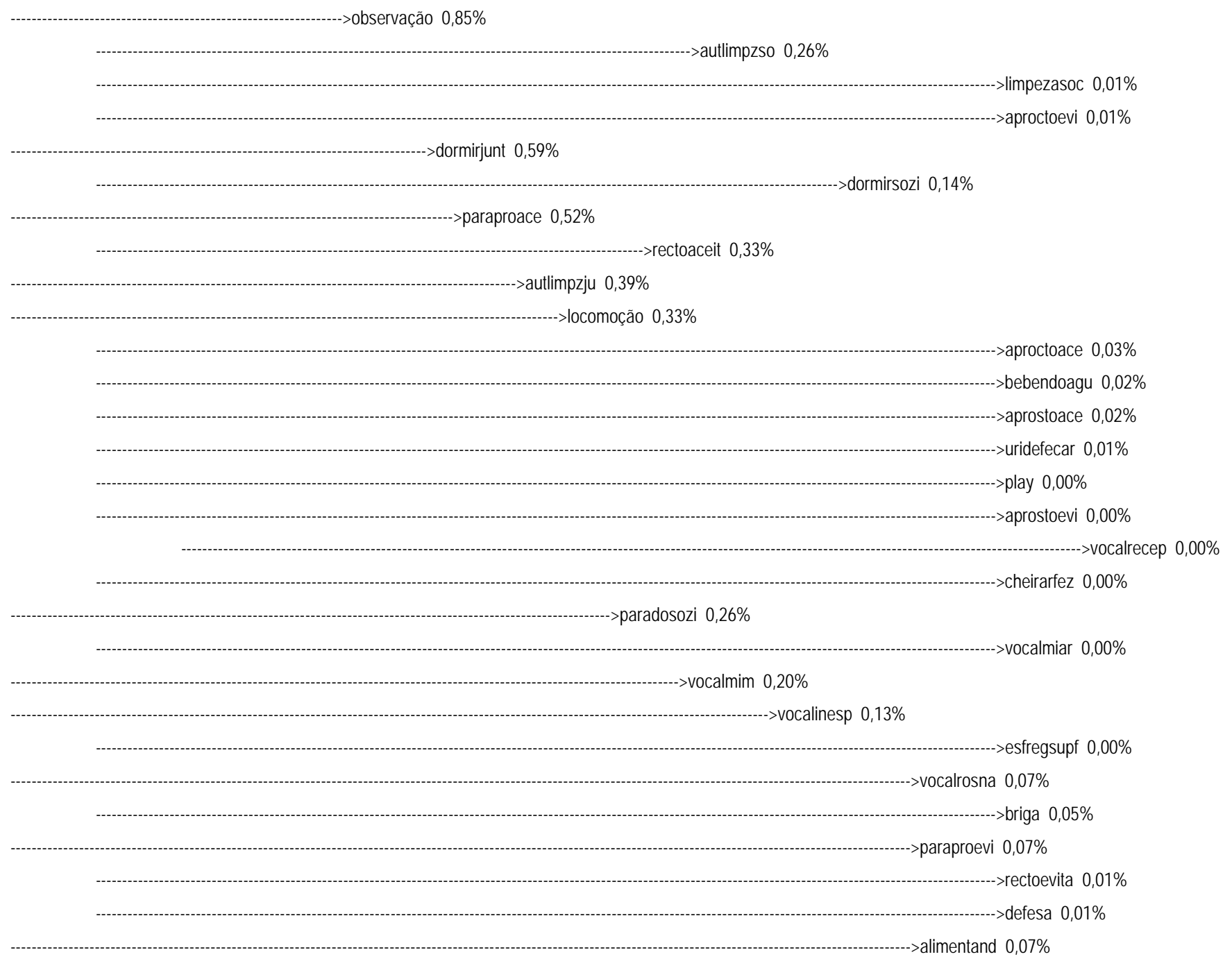

Figura 16.A - Ditree da categoria comportamental “Parado encostado em 1 ou + indivíduos” do grupo das fêmeas. 
pard1+indi

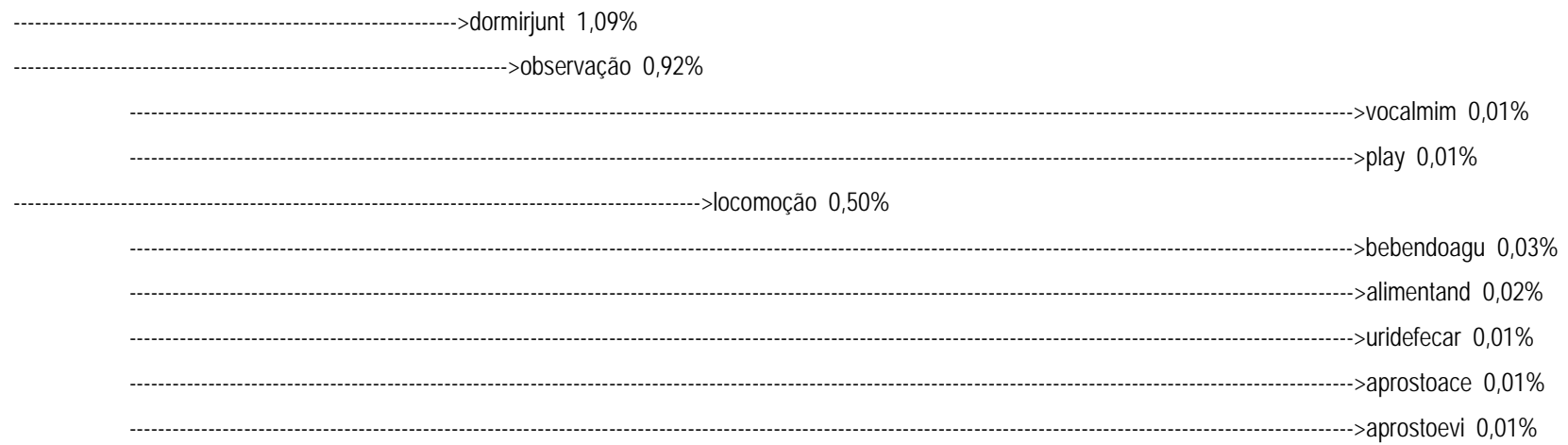

---->vocalrecep $0,00 \%$

-->esfregsupf $0,00 \%$

>apr2+indre $0,00 \%$

>vocalmiar 0,00\%

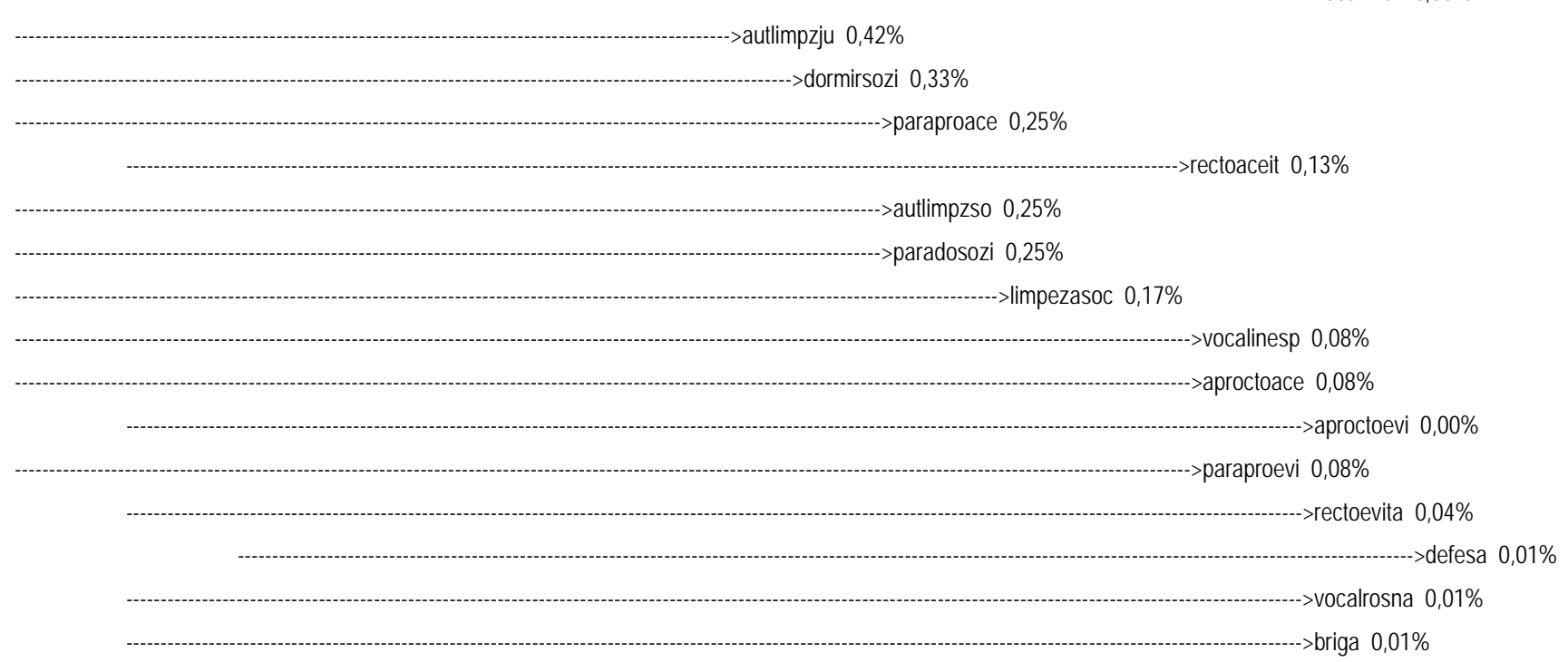

Figura 16.B - Ditree da categoria comportamental “Parado encostado em 1 ou + indivíduos” do grupo dos machos. 


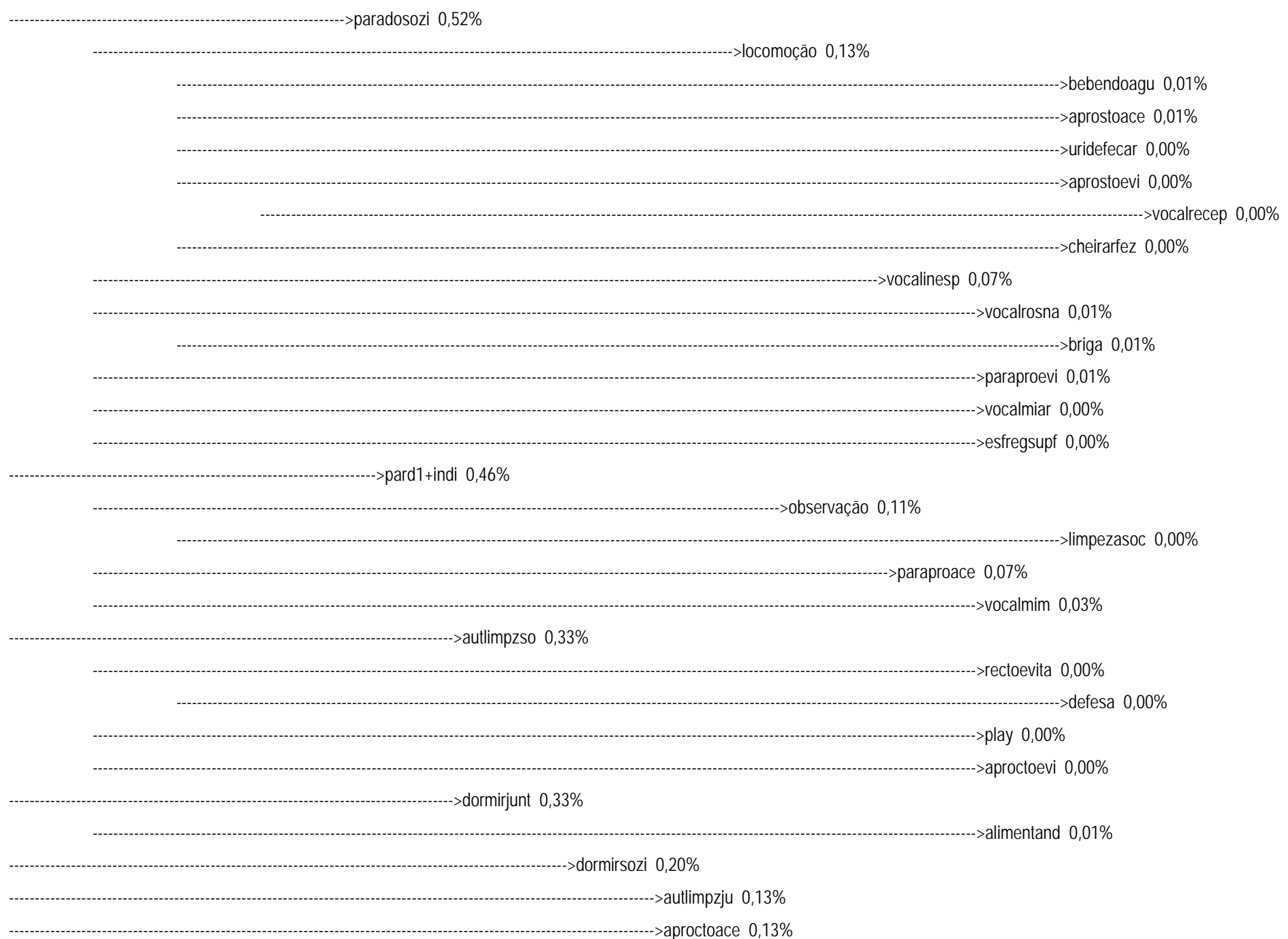

Figura 17.A - Ditree da categoria comportamental “Receber o toque de outros indivíduos e aceitar” do grupo das fêmeas. 
rectoaceit

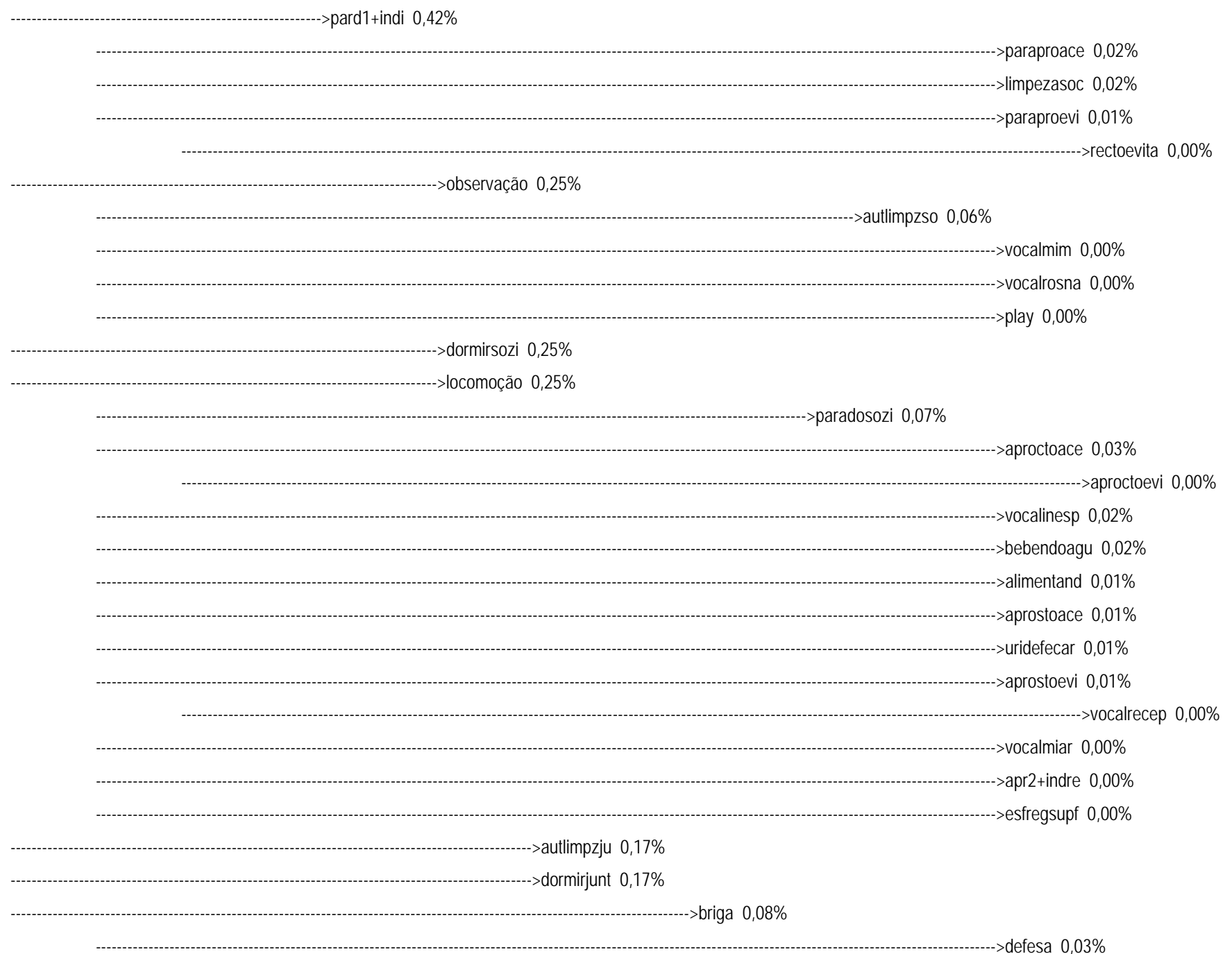

Figura 17.B - Ditree da categoria comportamental “Receber o toque de outros indivíduos e aceitar” do grupo dos machos. 
As figuras 18.A (Fêmeas) e 18.B (Machos) se referem a categoria comportamental "Vocalinesp” (Vocalização inespecífica). As fêmeas apresentam a seguinte seqüência depois da categoria raiz \{locomoção $(3,06)$, paradosozi $(1,76)$, observação $(0,72)$, autlimpzso $(0,59)$ \}, os machos apresentaram \{locomoção $(2,09)$, paradosozi $(0,84)$, observação $(0,67)$, aproctoace $(0,25)\}$. A primeira tríade é igual em ambos os gêneros, mas as probabilidades não significantes diferem em ambos. Sendo assim, apesar de alguns valores probabilísticos não serem significantes nota-se alguma diferença de machos e as fêmeas.

As figuras 19.A (Fêmeas) e 19.B (Machos) se referem a categoria comportamental "Vocalrosna” (Vocalização rosnar). As fêmeas apresentam o seguinte comportamento depois da categoria raiz \{briga $(0,78)\}$ o qual tem uma probabilidade significante, enquanto que os machos apresentam \{observação $(0,17)$ \}, sendo que nestes o comportamento "briga" tem a probabilidade zero. Notando-se assim a diferença entre os sexos em relação a esta categoria raiz. 
vocalinesp

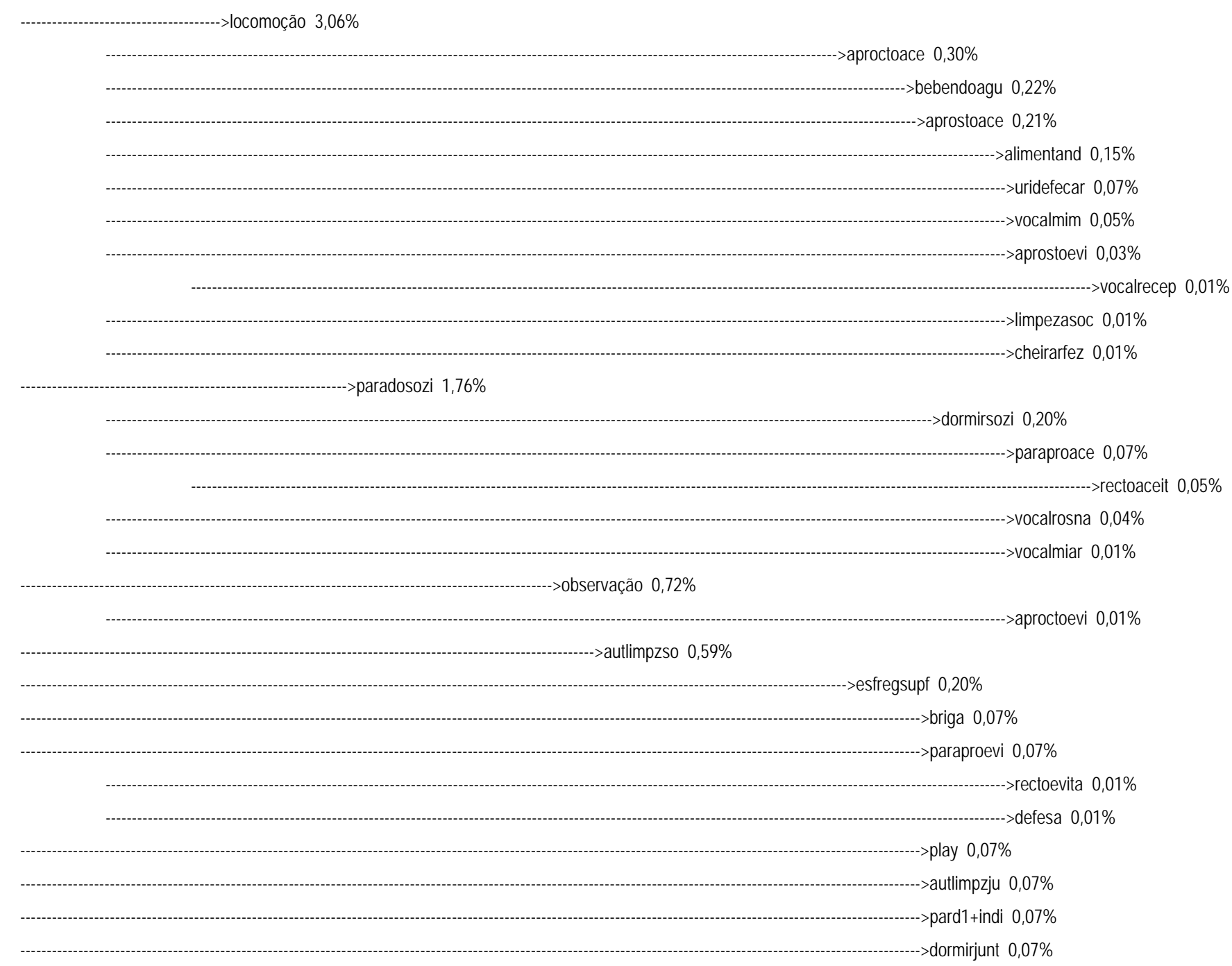

Figura 18.A - Ditree da categoria comportamental "Vocalização inespecífica” do grupo das fêmeas. 
vocalinesp

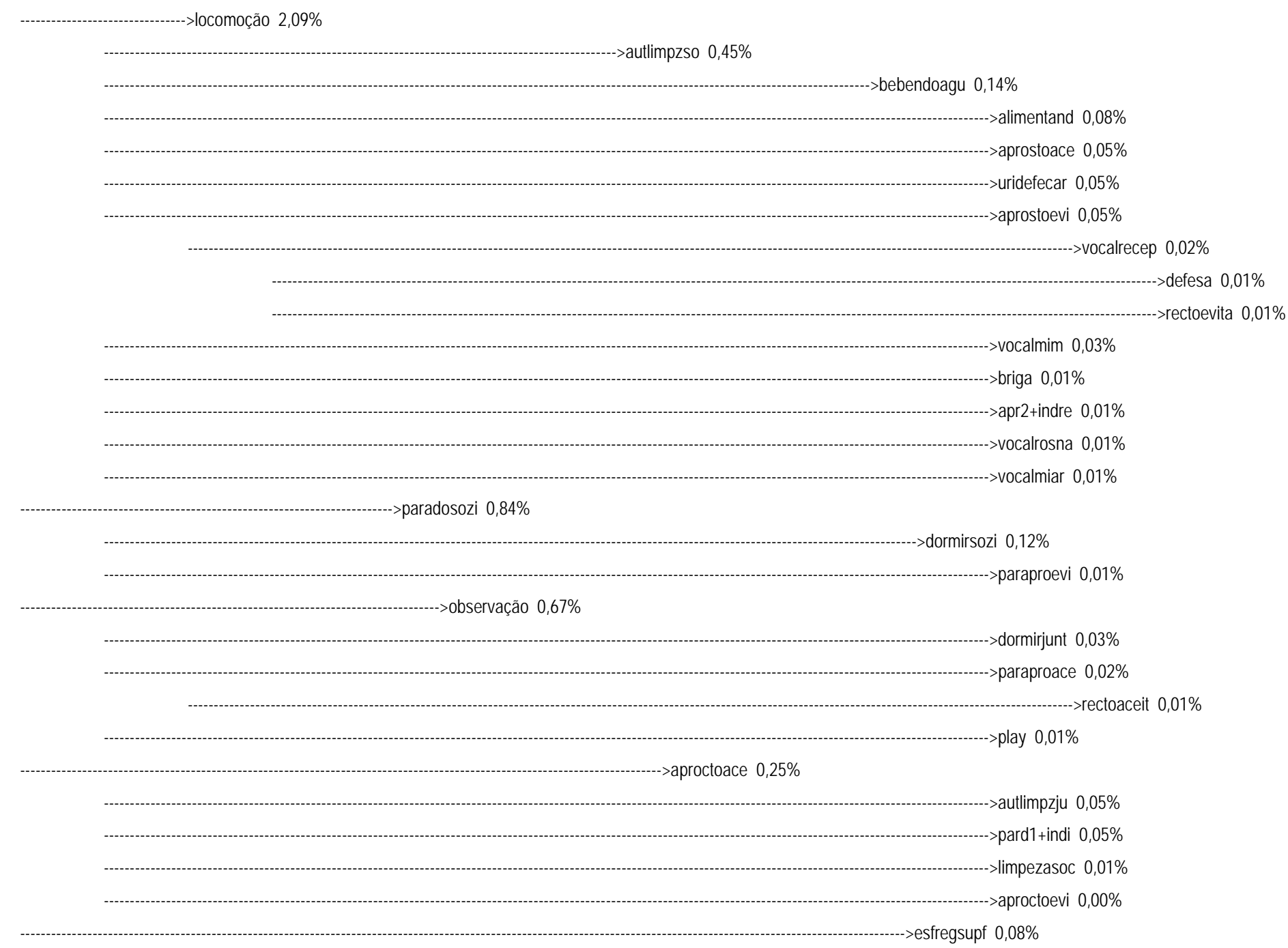

Figura 18.B - Ditree da categoria comportamental “Vocalização inespecífica” do grupo dos machos. 
vocalrosna

-------->briga $0,78 \%$

-

>paraproace $0,01 \%$

rectoaceit $0,01 \%$

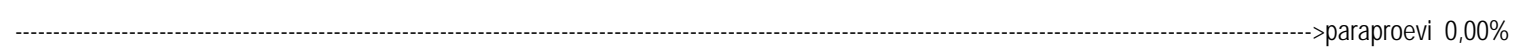

$>$ vocalmim $0,00 \%$

>vocalmiar $0,00 \%$

--o---->locomoção $0,16 \%$

$>$ bebendoagu $0,01 \%$

>aprostoace $0,01 \%$

$>$ uridefecar $0,00 \%$

$>$ play $0,00 \%$

$>$ aprostoevi $0,00 \%$

$>$ cheirarfez $0,00 \%$

>limpezasoc 0,00\%

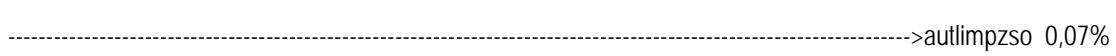

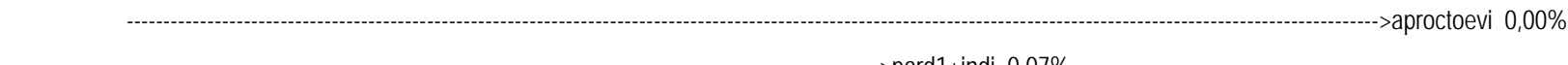

$\rightarrow$ pard1+indi $0,07 \%$

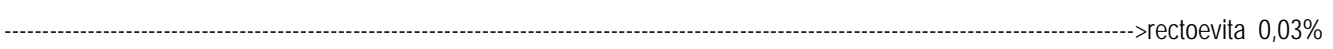

$\rightarrow$ alimentand $0,03 \%$

->dormirjunt $0,03 \%$

->defesa $0,07 \%$

$>$ vocalinesp $0,07 \%$

Figura 19.A - Ditree da categoria comportamental “Vocalização rosnar” do grupo das fêmeas. 
vocalrosna

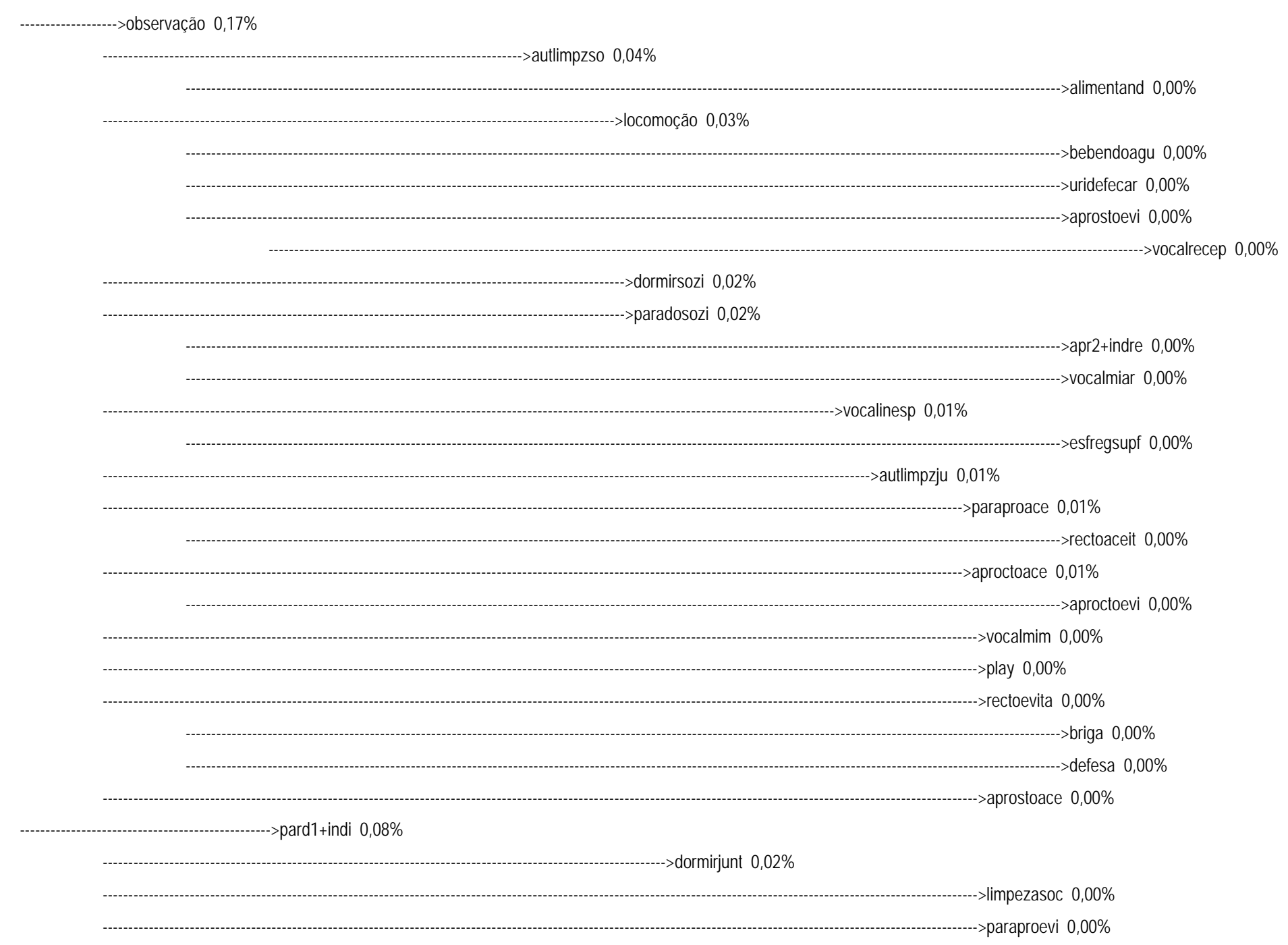

Figura 19.B - Ditree da categoria comportamental "Vocalização rosnar” do grupo dos machos. 


\section{DISCUSSÃO}

\subsection{Freqüência comportamental}

\subsubsection{Categorias comportamentais sociais}

Como foi visto em Resultados, não houve diferença significativa na freqüência das categorias comportamentais sociais entre os sexos, diferentemente do que ocorre com gatos não castrados. O comportamento afiliativo entre gatos não castrados, como as aproximações amigáveis, toques entre os outros indivíduos, são exibidos mais freqüentemente por fêmeas do que por machos (Barry e Crowell-Davis, 1999). As fêmeas formam grupos e vivem em cooperação mútua (Dards, 1983; Barry e Crowell-Davis, 1999), os machos são mais solitários e vagam entre vários grupos (Macdonald et al., 1987). Dessa forma os machos regulam as interações sociais evitando um ao outro e limitando assim a oportunidade de exibir o comportamento afiliativo.

Entretanto os animais deste estudo estão num espaço físico muito limitado com uma média de 2,6 animais por metro quadrado da área total, não considerando as áreas dos bancos, cadeiras e cestas. Isto forçou aos animais proximidade de uns aos outros. Sob estas condições, eles mantinham tal proximidade e exibiam vários comportamentos afiliativos como, aproximação amigável com toque ou não, mantendo o corpo em contato uns com os outros enquanto dormiam, parados em repouso, ou se esfregando ou cheirando uns aos outros, sustentando a idéia de que o gato doméstico é um animal social (veja a lista das categorias comportamentais sociais). Todos estes comportamentos foram considerados sociais de aceitação ou 
evitação. Assim sendo, apesar das diferenças comportamentais entre gatos machos e fêmeas não castrados participarem do conceito de comportamento social, este estudo mostrou que embora os animais não tenham mais a fonte produtora dos hormônios sexuais e conseqüentemente os comportamentos relacionados como a atividade sexual e comportamento social diferencial, uma sociabilidade entre os indivíduos deste gatil ainda se mantém. No entanto, a própria tolerância dos gatos machos castrados, entre si, no presente estudo, apesar da proximidade forçada, pode constituir uma evidência de que a castração altera o comportamento esperado nestes animais. Ou seja, onde se esperaria maior quantidade de interações agonísticas entre machos, devido à pequena distância, houve tolerância.

É observado nas tabelas 5 e 6 as freqüências das categorias comportamentais sociais. Pode-se ver que a freqüência das categorias de aproximação, de toques aceitos e de contato entre os indivíduos são maiores do que quando ocorria a evitação, evidenciando assim as relações amigáveis entre os indivíduos tanto machos como as fêmeas. No entanto as freqüências das categorias não sociais parado sozinho, dormindo sozinho e autolimpeza sozinho (tabelas 7 e 8) são maiores que as categorias sociais equivalentes, parado, dormindo e autolimpeza em contato com outros animais (tabelas 5 e 6) indicando que apesar do espaço limitado os animais, machos e fêmeas, ficavam distanciados um do outro, talvez, assim, evitando a proximidade. No entanto Natoli et al (2001) em seu estudo do comportamento social de gatos, sendo alguns castrados, considerou como parte do comportamento afiliativo a proximidade de 1, 3 e 5 metros entre os indivíduos do grupo. Sendo assim pode-se afirmar que apesar da freqüência maior das categorias de comportamento solitário os indivíduos estavam sempre próximos uns dos outros devido à alta densidade 2,6 gatos por metro quadrado. 
Além disso, este estudo mostrou através dos dados da análise da freqüência comportamental de fêmeas e machos, quando comparados com dados da literatura, que a castração influenciou os comportamentos espacial, social e os sinais afiliativos principalmente dos últimos. Dessa forma conclui-se a partir desta comparação, que nos animais não castrados, os hormônios influenciam os padrões comportamentais espacial, social (Hart e Barret, 1973; Barry e Crowell-Davis, 1999). Ainda, no atual estudo, foi mostrado o aumento da freqüência dos machos castrados ficarem em proximidade, com menor agressividade entre os mesmos, diferentemente do que ocorre com os machos não castrados (Barry e Crowell-Davis, 1999).

A evitação dos animais através da distribuição espacial e distribuição no tempo, assim como a tolerância entre os indivíduos são importantes mecanismos de prevenir a agressão (Leyhausen, 1979; van den Bos, 1998). No entanto nos animais em confinamento em ambiente de área restrita, tais mecanismos não podem ser realizados. Mas neste trabalho foi observada baixa freqüência de briga (tabelas 5 e 6) entre os animais, apesar do espaço reduzido, além de não haver diferença significativa entre machos e fêmeas em relação à categoria briga (tabela 1). Dessa forma, conclui-se que a castração parece ter agido diminuindo a agressão em ambos os sexos. Principalmente nos machos, pois entre gatos, assim como para a maioria dos mamíferos, o macho apresenta mais comportamentos agressivos (Mayer apud Barry e Crowell-Davis, 1999).

Entretanto há amplitudes individuais nas categorias, principalmente Vocalização rosnar e Briga (tabelas 5 e 6). Em ambas, a freqüência de 3 indivíduos fêmea (indivíduos 3, 17 e 22) foi alta (veja Gráficos 1 e 2 de freqüências individuais). Hart e Eckstein (1997) em seu trabalho com cães e gatos castrados observou que as fêmeas castradas mostraram comportamento agressivo. Isto pode estar relacionado com a idade na qual o animal foi castrado, pois se a castração ocorrer antes de 12 meses de 
idade e se feita de maneira repentina depois do estro, os animais podem mostrar alguma agressão. Uma possível explicação é que a castração remove a fonte de produção de progesterona, sendo que esta tem uma influência ansiolítica e quando há a remoção deste hormônio, nesta situação, em alguns animais podem aumentar os níveis de comportamentos agonísticos (Hart e Eckstein, 1997).

\subsubsection{Categorias comportamentais não sociais}

Não houve diferença significativa das categorias comportamentais não sociais entre os sexos, contudo há diferentes amplitudes das freqüências individuais na

maioria das categorias principalmente em relação a autolimpeza, locomoção e vocalização inespecífica, pois estas apresentam grandes freqüências.

Os comportamentos observados com maior freqüência em ambos os sexos foram locomoção, parado sozinho (repouso), autolimpeza e observação, (tabelas 7 e 8 em Resultados). Tais comportamentos com exceção da observação podem ser sinal de estresse, pois segundo van den Bos (1998) e Heidenberger (1997) o tédio ou falta de atividades é uma das maiores causas de estresse físico e comportamental em gatos confinados, de ambos os sexos.

O comportamento de autolimpeza é um comportamento freqüente em gatos, pois estes gastam uma boa parte de seu tempo realizando-o, sendo que tal padrão comportamental tem importante função na remoção de possíveis ectoparasitas, proteção dos pêlos e controle da temperatura corpórea. Como foi observado, todos os animais exibiram altas freqüências do comportamento de autolimpeza, as diferenças individuais foram maiores quando este foi exibido sozinho do que quando exibido em contato com outros animais (veja Gráficos 4 e 5 em Resultados).

Mas van den Bos (1998) mostrou em seu trabalho que o comportamento de autolimpeza com altas freqüências, entre outros não analisados aqui, é um indicativo 
de stress crônico e/ou agudo, principalmente em condições nas quais o gato não tem o controle, como o confinamento. Ainda, Willemse e Spruijt (1995) e van den Bos (1998) fizeram um estudo quantitativo no qual foi observado aumento na ocorrência de autolimpeza depois que os animais eram submetidos a espaços mínimos dentro de sua área de confinamento durante 15 minutos. A maior freqüência de autolimpeza em alguns animais pode ser um indício de que se ainda não apresentam o estresse, são possíveis canditados a desenvolverem tal manifestação patológica (van den Bos, 1998).

Outras amplitudes diferenciais individuais das freqüências das categorias comportamentais que podem estar relacionadas com distúrbios comportamentais, como a ansiedade e o estresse, foi a locomoção, muito freqüente em ambos os sexos (veja tabelas 7 e 8 e o Gráfico 3 em Resultados). Estes animais passam um período diário muito grande sob as condições do confinamento. De acordo com Mertens e Schar (1988) os problemas comportamentais aparecem principalmente em animais confinados. Estes autores propuseram que um espaço mínimo qualitativo e/ou quantitativo é essencial para os animais. Caso isto não ocorra os distúrbios comportamentais são inevitáveis. Além disso, considerando os fatores significantes relacionados com tais distúrbios, Heidenberger (1997) observou que a castração não preveniu o desenvolvimento dos problemas comportamentais. Ainda, nos animais castrados as fêmeas exibem problemas comportamentais mais freqüentemente do que os animais que não sofreram a castração assim como os gatos confinados com pouco acesso a “passeios” (Heidenberger, 1997).

Outra categoria que poderia indicar suscetibilidade ao estresse foi vocalização inespecífica (veja Gráfico 6 em Resultados), mostrando-se com maiores freqüências individuais especificamente nas fêmeas. 


\subsubsection{Locais}

Novamente não houve diferenças significativas entre machos e fêmeas em relação a todos os locais (veja tabela 3 em Resultados). No entanto há locais favoritos para diferentes animais, como as tábuas de madeira do gatil direito e esquerdo e o solo direito e esquerdo também (veja tabela 4 e anexo 1 em Resultados). O segundo teste estatístico separando os locais que apresentaram as maiores freqüências dos que apresentaram as menores freqüências (veja Resultados e lista dos locais na pg. 15 e tabela 4) também mostrou que não houve diferença significativa entre machos e fêmeas no acesso aos locais preferenciais (veja tabela 3.1 em Resultados).

Os gatos domésticos confinados geralmente não têm a oportunidade de estabelecer território adequado, enquanto que os gatos ferais podem ter territórios de 0,51 a 620 ha. (Beaver apud Lindell et al, 1997). Já nos animais confinados paredes e portas determinam o seu espaço territorial. É mostrado na literatura que os gatos são capazes de estabelecer um contato social e apresentam uma grande variabilidade comportamental relacionada ao uso do espaço (Liberg e Sandell, 1988; Natoli e De Vito, 1991). Devido a esta flexibilidade espacial os gatos confinados ocupam as áreas favoritas numa seqüência temporal (Bernstein e Strack, 1993; Lindell et al, 1997). Além disso, os gatos confinados toleram o restrito espaço e o contato com outros gatos sem exibição de comportamento agressivo (Lindell et al, 1997).

Bernstein e Strack (1996) e Barry e Crowell-Davis (1999) mostraram em seus estudos com gatos castrados que embora diferentes gatos tenham locais preferenciais diferentes, a maioria dos gatos sobrepõe o espaço territorial. Indicando assim que a prática da castração auxilia na manutenção de gatos adultos principalmente os machos, num espaço limitado, já que estes se mostram menos agressivos quando castrados, em tal condição de confinamento, como é mostrado neste estudo e no relato da literatura (Bradshaw e Hall, 1999). 


\subsubsection{Individualidade}

Diferenças individuais sem dúvida alguma influenciam a formação das relações individuais, pois os gatos diferem fortemente em características e personalidade, sendo possível reconhecer fácil e claramente as diferenças comportamentais individuais (Karsh e Turner, 1988) dos gatos castrados ou não. Isto é sustentado pelo fato que o gato doméstico exibe uma grande variação individual no seu comportamento social dirigido a outros gatos (Kerby e Macdonald, 1988).

Uma das explicações do significado funcional de padrões comportamentais diferentes está relacionado com os custos e benefícios para a sobrevivência do animal de se comportar numa determinada forma. Além disso o comportamento é dependente também das condições ambientais. Em certas condições, os benefícios de se comportar numa determinada forma são alterados e portanto diferentes tipos de comportamento são mais vantajosos para a sobrevivência do animal (Mendl e Harcourt, 1988). Uma outra explicação para a existência da variação intraespecífica na expressão de um padrão comportamental é que, na média as diferentes formas de se comportar são igualmente bem sucedidas (Mendl e Harcourt, 1988). Esta variação comportamental pode ser quantificada usando técnicas para medir não somente diferenças nas freqüências de um comportamento particular, mas também diferenças em mais características gerais do comportamento como um todo (Mendl e Harcourt, 1988).

Neste estudo houve amplitudes individuais distintas na freqüência das categorias comportamentais sociais e não sociais (veja tabelas 5, 6, 7, 8 e gráficos 1, 2, 3, 4, 5, 6 em Resultados). Há muitas possíveis influências nas diferenças individuais, incluindo socialização diferencial e respostas diferenciais aos vários ambientes (Barry e Crowell-Davis, 1999). A estrutura social de grupos de gatos depende das 
características individuais dos membros deste grupo (Leyhausen, 1979; Durr e Smith, 1997). Além disso, pode haver uma vantagem evolutiva para seleção das características individuais. Com isso o gato pôde ser capaz de apresentar uma flexibilidade comportamental para várias condições ecológicas (Durr e Smith, 1997).

A castração pode afetar o comportamento diferentemente entre os sexos e dentro dos sexos de uma espécie e entre as espécies (Hart e Eckstein, 1997) fazendo com que se mantenha tal individualidade dos animais mesmo com a supressão hormonal.

\subsection{Seqüência comportamental}

Depois da análise seqüencial das árvores orientadas, observou-se a presença de diferenças seqüenciais comportamentais entre fêmeas e machos na maioria das Ditrees, apesar de todas elas exibirem praticamente os mesmos comportamentos com probabilidades mais altas, mostrando que as diferenças ocorrem na ordem seqüencial dos mesmos. As diferenças de seqüências ocorreram especificamente nas árvores 1A/1B, 2A/2B, 7A/7B, 8A/8B, 9A/9B, 10A/10B, 11A/11B, 13A/13B, 14A/14B, 15A/15B, 17A/17B, 19A/19B. Destas, em muitas das árvores a semelhança entre fêmeas e machos pode ser explicada devido a castração. São elas 2A/2B, 7A/7B, 8A/8B, 9A/9B, 10A/10B, 11A/11B, 12A/12B, 13A/13B, 14A/14B, 15A/15B, 17A/17B, 19A/19B.

A Ditree 2A/2B (Aproctoace) mostrou pouca semelhança no início, somente a primeira categoria estatisticamente significante foi idêntica depois da categoria raiz em ambas as árvores, o resto da seqüência comportamental diferiu em ambas, o mesmo ocorreu com a Ditree 8A/8B (Defesa). Nos machos a alta probabilidade de ocorrência dos comportamentos na árvore 2B “autlimpzju” (Autolimpeza encostado em 1 ou + indivíduos - 0,92\%) e "pard1+ind" (Parado encostado em 1 ou + 
indivíduos - 0,92\%) mostra que a castração influenciou no comportamento social e os sinais afiliativos dos machos.

É observado na Ditree 7A/7B (Briga) diferenças na seqüência dos comportamentos e suas probabilidades de ocorrências de fêmeas e machos, sendo que estes últimos mostraram-se mais defensivos, pois a categoria “defesa” teve probabilidade de $(0,17)$ enquanto que as fêmeas mostraram-se mais agressivas, categoria "vocalrosna" $(0,20)$. A partir disto pode-se concluir a presença dos efeitos da castração nos machos, tornando-os mais pacatos.

Nas Ditrees 9A/9B (Dormirjunt), 10A/10B (Dormirsozi), 17A/17B (Rectoaceit) 11A/11B (Locomoção), 12A/12B (Observação), 14A/14B (Paraproace), nas três primeiras árvores as diferenças estão em todas as seqüências comportamentais, nas três últimas há semelhança nas díades iniciais, mas em seguida há distinção nas seqüências de fêmeas e machos. No entanto em todas as árvores há os comportamentos sociais de aproximação e toques como (aproctoace), (rectoaceit), (paraproace), (pard1+ind), (autlimpzju) com probabilidades de ocorrência significantes. Conclui-se portanto que a castração influenciou o comportamento social e os sinais afiliativos principalmente dos machos.

Na Ditree 13A/13B (Paradosozi) inicialmente a primeira díade é idêntica em ambas árvores, em seguida há diferenças na seqüência dos comportamentos com maiores probabilidades de ocorrência, ainda que sejam os mesmos em ambas. Analisando-se os comportamentos com menores probabilidades de ocorrência, percebe-se diferenças entre fêmeas e machos na seqüência e nas probabilidades como as categorias "vocalrosna” e "briga”. Nas fêmeas as probabilidades são $(0,39)$ e $(0,31)$, enquanto que nos machos $(0,04)$ e $(0,08)$. Conclui-se portanto que a castração influenciou o comportamento social e os sinais afiliativos principalmente dos machos e as fêmeas mostraram uma maior agressividade. 
A Ditree 15A/15B (Paraproevi) apresenta probabilidades de ocorrência comportamentais baixas, mas há diferenças entre fêmeas e machos. As fêmeas mostram uma tendência mais agressiva, pois a maior probabilidade de ocorrência depois da categoria raiz é a categoria "briga” (0,26). A Ditree 19A/19B (Vocalrosna) também mostra esta tendência mais agressiva das fêmeas pois, a maior probabilidade de ocorrência depois da categoria raiz é a categoria "briga” $(0,78)$, enquanto que nos machos é “observação” $(0,17)$. Esta suposta agressividade das fêmeas, também foi observada na análise da freqüência comportamental de 3 indivíduos fêmea (veja gráficos 1 e 2 em Resultados e Discussão da freqüência comportamental na pg. 93).

Como foi observado, na análise seqüencial do comportamento das Ditrees as categorias comportamentais de aproximação (aproctoace), toques (rectoaceit) e contato (paraproace), (pard1+ind) relacionadas com a aceitação tiveram maiores probabilidades de ocorrência depois da maioria das categorias raiz, do que as categorias comportamentais equivalentes a estas, mas de evitação (aproctoevi), (rectoevit), paraproevi), tanto para os machos como para as fêmeas. Esta mesma conclusão foi também observada na análise da freqüência comportamental, pois estes comportamentos de aceitação apresentaram maiores freqüências (veja Discussão pg. 92). Assim sendo, a partir deste resultado conclui-se que a castração influenciou os comportamentos espacial, social e os sinais afiliativos principalmente dos machos, deixando-os mais pacatos e gregários.

Entretanto foi observado também na análise das Ditrees, maiores probabilidades de ocorrência depois da maioria das categorias raiz, as categorias (paradosozi) e (autlimpzso) tanto nas fêmeas como nos machos. Esta mesma conclusão foi observada na análise de freqüência comportamental, pois estas mesmas categorias comportamentais apresentaram maiores freqüências, indicando assim que apesar do espaço limitado os animais, machos e fêmeas, ficavam distanciados um do outro, 
talvez assim evitando a proximidade (veja Discussão nas pgs 92 e 93). A evitação dos animais através da distribuição espacial e distribuição no tempo, assim como a tolerância entre os indivíduos são importantes mecanismos de prevenir a agressão (Leyhausen apud van den Bos, 1998). No entanto nos animais em confinamento tais mecanismos não podem ser realizados. Dessa forma, conclui-se que a castração parece ter agido diminuindo a agressão em ambos os sexos. Principalmente nos machos, onde se esperaria maior agressividade (Mayer apud Barry e Crowell-Davis, 1999).

Outras categorias com maiores probabilidades de ocorrência depois da maioria das categorias raiz nas Ditrees analisadas, foram (observação), (locomoção), (autlimpzso) e (vocalinesp), tanto nas fêmeas como nos machos. Estes comportamentos, exceto (observação), com maiores freqüências podem ser um indício de estresse, como foi visto na análise de freqüência comportamental (veja em Discussão pgs. 94 e 95). Analisando-se as árvores raiz 11A/11B (locomoção) e 5A/5B (autlimpzso), percebe-se que a categoria comportamental (vocalinesp) tem maiores probabilidades de ocorrência, assim como se analisarmos a árvore raiz 18A/18B (vocalinesp), as categorias com maiores probabilidades de ocorrência são justamente (locomoção) e (autlimpzso). Estes dados confirmam as maiores freqüências destas categorias comportamentais na análise de freqüência comportamental.

No entanto, apesar da existência de todos estes comportamentos observados com maiores probabilidades de ocorrência em praticamente todas as árvores de machos e fêmeas, é a seqüência comportamental das Ditrees o que mostra diferenças ou semelhanças entre os sexos, ou seja, a comparação das árvores de fêmeas e machos com uma determinada raiz mostrando as probabilidades de suas díades (seqüências comportamentais de duas categorias ligadas). Como foi observado que as seqüências 
dos comportamentos diferiram entre os machos e as fêmeas em praticamente todas as árvores analisadas, apesar dos comportamentos com maiores probabilidades de ocorrência serem os mesmos, conclui-se que do ponto de vista do método da análise seqüencial existem diferenças comportamentais entre os machos e as fêmeas castrados. Enquanto que o método estatístico da análise de freqüência comportamental mostrou que não houve diferenças entre os sexos. Portanto é concluído assim que este método seqüencial do comportamento é refinado o suficiente para mostrar características comportamentais diferentes entre os grupos analisados que não poderiam ser mostrados de outra maneira.

O comportamento como um todo dos machos e fêmeas castrados é semelhante devido a ausência da fonte hormonal, como já foi mostrado principalmente pela análise de freqüência comportamental, principalmente dos machos, os quais mostraram-se mais gregários, vivendo em grupos devido também ao confinamento e em cooperação mútua, características estas do comportamento de fêmeas, enquanto que os machos não castrados são mais solitários e vagam entre vários grupos, regulam as interações sociais evitando um ao outro e limitam assim a oportunidade de exibir o comportamento afiliativo. No entanto a partir da análise seqüencial percebese que uma mínima diferença entre os machos e fêmeas castrados permaneceu, mesmo na ausência da regulação hormonal do comportamento. 


\section{CONCLUSÃO}

Este trabalho revelou a partir das análise de frequêencia e seqüência comportamental que a prática da castração e, consequentemente, a alteração hormonal tem influência nos comportamentos sexual, espacial e social, dos gatos machos e fêmeas, especialmente nos primeiros, os quais mostraram mudanças visíveis quando comparados com o relato da literatura dos machos não castrados, ainda que preservando a individualidade dos animais. Contudo a análise seqüencial mostrou uma mínima diferença entre os machos e fêmeas castrados mesmo na ausência da regulação hormonal do comportamento. Portanto conclui-se, assim, que o método seqüencial do comportamento é refinado o suficiente para mostrar características comportamentais entre grupos analisados que não poderiam ser mostrados de outra maneira. Esta diferença pode ser devido à história de vida diferente dos diversos animais, mostrando uma influência "cultural" sobre o comportamento social.

Foi mostrado também que talvez devido à individualidade nos animais em confinamento, a castração não preveniu o desenvolvimento de padrões comportamentais (maior freqüência e maior probabilidade de ocorrência na análise seqüencial dos comportamentos de autolimpeza e locomoção) os quais podem estar relacionados a problemas de estresse e ansiedade devidos a condição confinada. 


\title{
7. REFERÊNCIAS BIBLIOGRÁFICAS*
}

\begin{abstract}
ALBERTS, C. C. O comportamento de autolimpeza do Gato Doméstico (Felis catus) e uma proposta para usá-lo como caractere filogenético. 1996. 124 p. Tese Doutorado - Instituto de Psicologia, Universidade de São Paulo, São Paulo.
\end{abstract}

. Evolução da socialidade em felinos: contribuição da filogenia. In Albuquerque, FS (org.) Anais do XX Encontro Anual de Etologia. 2002. Natal, RN, p 112-124.

ARNOLD, A. P. \& GORSKI, R. A. Gonadal steroid induction of structural sex differences in the nervous system. Ann. Rev. Neurosci., 7, p. 413-442, 1984.

BARRY, J. K. \& CROWELL-DAVIS, L. S. Gender differences in the social behavior of neutered indoor-only domestic cat. Appl. Anim. Behav. Sci., 64, p. 193211, 1999.

BATESON, P. \& TURNER, C. D. Questions about cats. In Turner, D.C. \& Bateson, P. “The domestic cat”. $5^{\text {th }}$ reprinting. Cambridge: Cambridge University Press, 1988. cap. 14, p. 193-201. 
BERNSTEIN, P. L. \& STRACK, M. Home ranges, favored spots, time-sharing patterns, and tail usage by 14 cats in the home. Anim. Behav., 10 (3), p. 1-3, 1993.

BERNSTEIN, P. L. \& STRACK, M. A game of cat and house: spatial patterns and behavior of 14 domestic cats (Felis catus) in the home. Anthrozoos, 9 p. 25-39, 1996.

BRADSHAW, J. W. S. \& COOK, E. Patterns of pet cat behaviour at feeding occasions. Appl. Anim. Behav. Sci., 47, p. 61-74, 1996.

BRADSHAW, J. W. S. \& HALL, L. S. Affiliative behaviour of related and unrelated pairs of cats in catteries: a preliminary report. Appl. Anim. Behav. Sci., 63, p. 251-255, 1999.

DARDS, J. L. The behaviour of dockyard cats: interactions of adult males. Appl. Anim. Ethol., 10, p. 133-153, 1983.

DE BOER, J. N. Dominance relations in pairs of domestic cats. Behav. Process., 2, p. 227-242, 1977.

DURR, R. \& SMITH, C. Individual differences and their relation to social structure in domestic cats. J. Comp. Psych., 111 (4), p. 412-418, 1997.

HALL, L. S. \& BRADSHAW, J. W. S. The influence of hunger on object play by adult domestic cats. Appl. Anim. Behav. Sci., 58, p. 143-150, 1998. 
HART, B. L. \& BARRET, R. Effects of castration on fighting, roaming and urine marking in adult male cats. J.A.V.M.A., 103, p. 290-292, 1973.

HART, B. L. \& ECKSTEIN, A. R. The role of gonadal hormones in the occurrence of objectionable behaviours in dogs and cats. Appl. Anim. Behav. Sci., 52, p. 331-344, 1997.

HEIDENBERGER, E. Housing conditions and behavioral problems of indoor cats as assessed by their owners. Appl. Anim. Behav. Sci., 52, p. 345-364, 1997.

HOFFMAN, H. O Gato. Tradução do Inglês Valter Lellis Siqueira. São Paulo: Editora Martins Fontes, 1997. 173 p. Título original: Katzen Richtig Verstehen.

HORWITZ, D. F. Behavioral and environmental factors associated with elimination behavior problems in cats: a retrospective study. Appl. Anim. Behav. Sci., 52, p. 129-137, 1997.

KARSH, B. E. \& TURNER, D. C. The human-cat relationship. In Turner, D.C. \& Bateson, P. “The domestic cat”. $5^{\text {th }}$ reprinting. Cambridge: Cambridge University Press, 1988. cap. 12, p. 159-177.

KERBY, G. \& MACDONALD, D. W. Cat society and the consequences of colony size. In Turner, D.C. \& Bateson, P. “The domestic cat”. $5^{\text {th }}$ reprinting. Cambridge: Cambridge University Press, 1988. cap. 6, 67-81. 
LEHNER, P. N. Handbook of Ethological Methods. New York: Garland STPM Press, 1979. 413 p.

LEYHAUSEN, P. Uber die Funktion der relativen Stimmungshierarchie. Z. Tierpsychol., 22, p. 412-494, 1965.

LEYHAUSEN, P. Cat Behavior: The predatory and social behaviour of domestic cats and wild cats. New York: Garland STPM Press, 1979.

LEYHAUSEN, P. The tame and the wild - another Just-So Story? In Turner, D.C. \& Bateson, P. “The domestic cat”. $5^{\text {th }}$ reprinting. Cambridge: Cambridge University Press, 1988. cap. 5, p. 57-66.

LIBERG, O. \& SANDELL, M. Spatial organization and reproductive tactics in the domestic cat and other felids. In Turner, D.C. \& Bateson, P. “The domestic cat”. $5^{\text {th }}$ reprinting. Cambridge: Cambridge University Press, 1988. cap. 7, p. 83-98.

LINDELL, E. M. \& ERB, H. N. \& HOUPT, K. A. Intercat aggression: a retrospective study examining types of aggression, sexes of fighting pairs, and effectiveness of treatment. Appl. Anim. Behav. Sci., 55, p. 153-162, 1997.

MACDONALD, D. W. \& APPS, P. J. \& CARR, G. M. \& KERBY, G. Social dynamics, nursing coalitions and infanticide among farm cats. Felis catus. Adv. Ethol. 28, p. 1-66, 1987. 
MARTIN, P. \& BATESON, P. Measuring behaviour. Cambridge: Cambridge University Press, 1986. 200 p.

MARTIN, P. \& BATESON, P. Behavioural development in the cat. In Turner, D.C. \& Bateson, P. “The domestic cat”. $5^{\text {th }}$ reprinting. Cambridge: Cambridge University Press, 1988. cap. 2, p. 9-22.

MENDL, M. \& HARCOURT, R. Individuality in the domestic cat. In Turner, D.C. \& Bateson, P. “The domestic cat”. $5^{\text {th }}$ reprinting. Cambridge: Cambridge University Press, 1988. cap. 4, p. 41-53.

MERTENS, C. Human-cat interactions in the home setting. Anthrozoos, 4, p. 214-231, 1991.

MERTENS, C. \& SCHAR, R. Practical aspects of research on cats. Turner, D.C. \& Bateson, P. “The domestic cat”. $5^{\text {th }}$ reprinting. Cambridge: Cambridge University Press, 1988. cap. 13, p. 179-190.

MIRMOVITCH, V. Spatial organization of Urban Feral Cats ( Felis catus) in Jerusalem. Wildl. Res., 22, p. 299-310, 1995.

NATOLI, E. \& DE VITO, E. Agonistic behaviour, dominance rank and copulatory success in a large multi-male feral cat, Felis catus L., colony in central Rome. Anim. Behav., 42, p. 227-241, 1991. 
NATOLI, E. \& BAGGIO, A. \& PONTIER, D. Male and female agonistic and affiliative relationships in a social group of farm cats. Behav. Proc., 53, p. 137-143, 2001.

PACKER, C. \& PUSEY, A. E. Cooperation and competion in lions. Nature, Lond., 302, p. 356, 1983.

ROBINSON, R. Genetics for cat breeders. Oxford: Pergamon Press, 1971. $191 \mathrm{p}$.

SERPELL, A. J. The domestication and history of the cat. In Turner, D.C. \& Bateson, P. “The domestic cat”. $5^{\text {th }}$ reprinting. Cambridge: Cambridge University Press, 1988. cap. 11, p. 151-158.

SIEGEL, S. Estatística não paramétrica para as ciências do comportamento. Editora McGraw-Hill do Brasil, 1975. 350 p.

TURNER, D. C. \& BATESON, P. Why the cat? In Turner, D.C. \& Bateson, P. “The domestic cat”. $5^{\text {th }}$ reprinting. Cambridge: Cambridge University Press, 1988. cap. 1, p. 3-5.

VAN DEN BOS, R. Post-conflit stress-response in confined group-living cats (Felis silvestris catus). Appl. Anim. Behav. Sci., 59, p. 323-330, 1998. 
VOITH, V. L. \& BORCHELT, P. L. Social behavior of domestic cats. In: V. L. Voith and P. L. Borchelt (Editors), Read. Compan. Anim. Behav. Trenton: Veterinary Learning Systems, NJ. 1996. p. 248-256.

WALKER. Mammals of the World. Fifth Edition, Baltimore and London: The Johns Hopkins University Press, 1991. p. 1184-1187.

WILLEMSE, T. \& SPRUIJT, B. M. Preliminary evidence for dopaminergic involvement in stress-induced excessive grooming in cats. Neurosci. Res. Comm., 17 p. 203-208, 1995.

*De acordo com a Norma Técnica da ABNT NBR 6023 - Informação e Documentação - Referências Elaboração (ago./2000). Abreviatura de periódicos segundo Norma técnica da ABNT 6032 - Abreviação de Título de Periódicos e Publicações Seriadas (ago./1989). 


\section{ANEXO 1}

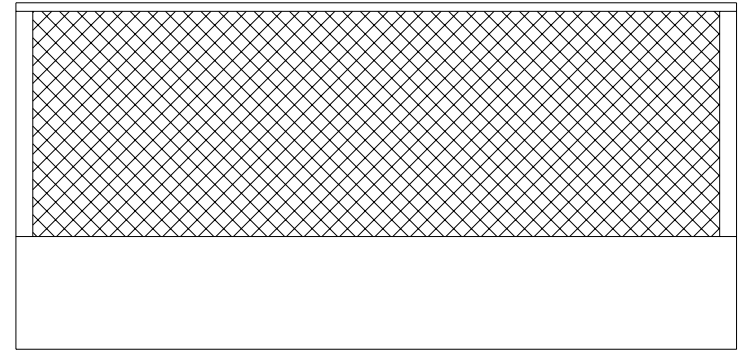

VISTA FRONTAL

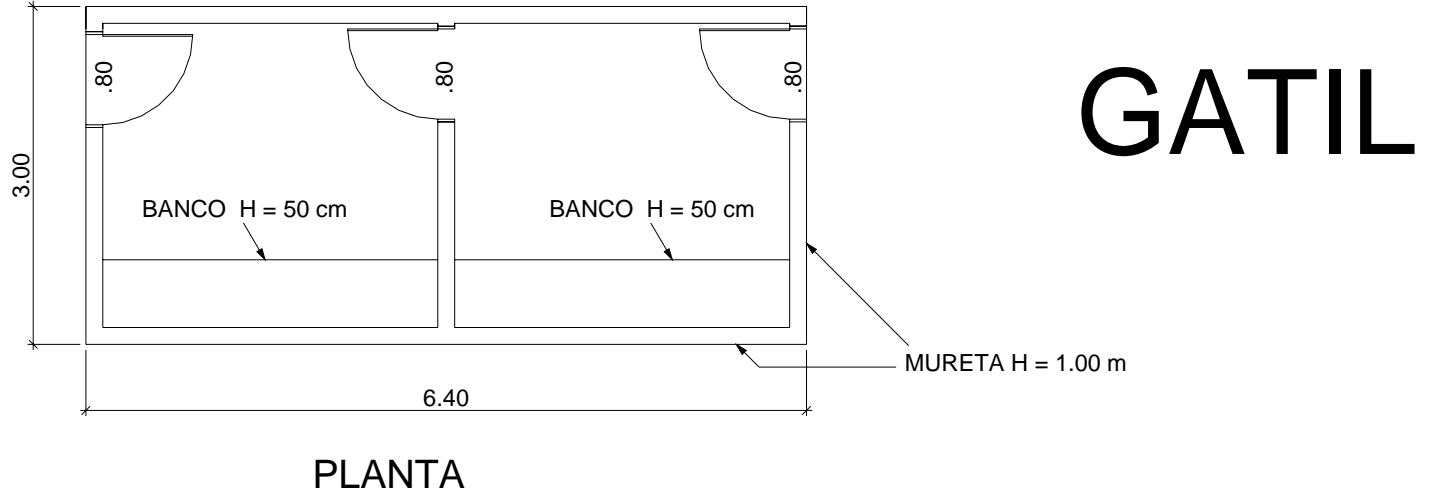


ANEXO 2

Animal:

Sessão de observação:

Data:

Início:

Tempo:

Localização inicial:

\begin{tabular}{|c|c|c|c|c|c|c|c|c|c|c|c|c|c|c|c|c|c|c|c|c|c|c|c|c|c|}
\hline \multicolumn{4}{|c|}{ A } & & \multicolumn{2}{|c|}{ B } & \multicolumn{6}{|c|}{ C } & \multicolumn{7}{|c|}{ D } & $E$ & & $\mathrm{~F}$ & G & H I & $\mathrm{J}$ \\
\hline 1 & 2 & 3 & 4 & 5 & 1 & 2 & 1 & 2 & 3 & 4 & 5 & 6 & 7 & 8 & 1 & 2 & 3 & 4 & 5 & 1 & 2 & & & & \\
\hline & & & & & & & & & & & & & & & & & & & & & & & & & \\
\hline & & & & & & & & & & & & & & & & & & & & & & & & & \\
\hline & & & & & & & & & & & & & & & & & & & & & & & & & \\
\hline & & & & & & & & & & & & & & & & & & & & & & & & & \\
\hline & & & & & & & & & & & & & & & & & & & & & & & & & \\
\hline & & & & & & & & & & & & & & & & & & & & & & & & & \\
\hline & & & & & & & & & & & & & & & & & & & & & & & & & \\
\hline & & & & & & & & & & & & & & & & & & & & & & & & & \\
\hline & & & & & & & & & & & & & & & & & & & & & & & & & \\
\hline & & & & & & & & & & & & & & & & & & & & & & & & & \\
\hline & & & & & & & & & & & & & & & & & & & & & & & & & \\
\hline & & & & & & & & & & & & & & & & & & & & & & & & & \\
\hline & & & & & & & & & & & & & & & & & & & & & & & & & \\
\hline & & & & & & & & & & & & & & & & & & & & & & & & & \\
\hline & & & & & & & & & & & & & & & & & & & & & & & & & \\
\hline & & & & & & & & & & & & & & & & & & & & & & & & & \\
\hline & & & & & & & & & & & & & & & & & & & & & & & & & \\
\hline & & & & & & & & & & & & & & & & & & & & & & & & & \\
\hline & & & & & & & & & & & & & & & & & & & & & & & & & \\
\hline & & & & & & & & & & & & & & & & & & & & & & & & & \\
\hline & & & & & & & & & & & & & & & & & & & & & & & & & \\
\hline
\end{tabular}

Anotações: 
Lista das abreviações da tabela:

A - Vocalizações:

A1: vocalz. p/ humanos, A2: vocalz.inespecífica, A3: vocalz.rosnar, A4: vocalz. miar, A5: vocalz. receptor.

B-Brigas:

B1: briga, B2: defesa

C - Aproximações e Toques:

C1: Aprostoace - Aproximação de algum indivíduo sem tocar e ser aceito.

C2: Aprostoevi - Aproximação de algum indivíduo sem tocar e ser evitado.

C3: Aproctoace - Aproximação de algum indivíduo com o toque e ser aceito.

C4: Aproctoevi - Aproximação de algum indivíduo com o toque e ser evitado.

C5: Apr2+indre - Aproximação de 2 ou mais indivíduos e um ou mais destes se retiram.

C6: Rectoaceit - Receber o toque de outro indivíduo e aceitar.

C7: Rectoevita - Receber o toque de outro indivíduo e evitar.

C8: Limpezasoc - Limpeza social.

$\underline{\text { D - Dormindo/Acordado }}$

D1: Dormirsozi - Dormindo sozinho.

D2: Dormirjunt - Dormindo ou sonolento (olhos serrados) encostado em um ou mais indivíduos.

D3: Paradosozi - Parado/acordado sozinho.

D4: Pard1+indi - Parado/acordado encostado em 1 ou mais indivíduos

D5: Paraproace ou Paraproevi - Parado e ocorre aproximação de outro indivíduo, este é aceito ou evitado.

E-Autolimpeza

E1: Autolimpeza sozinho.

E2: Autolimpeza encostado em 1 ou mais indivíduos.

F- Observação

G - Play ou Esfregar-se em superfícies

$\mathrm{H}$ - Alimentar-se ou beber água

I - Urinar/Defecar 
ANEXO 3

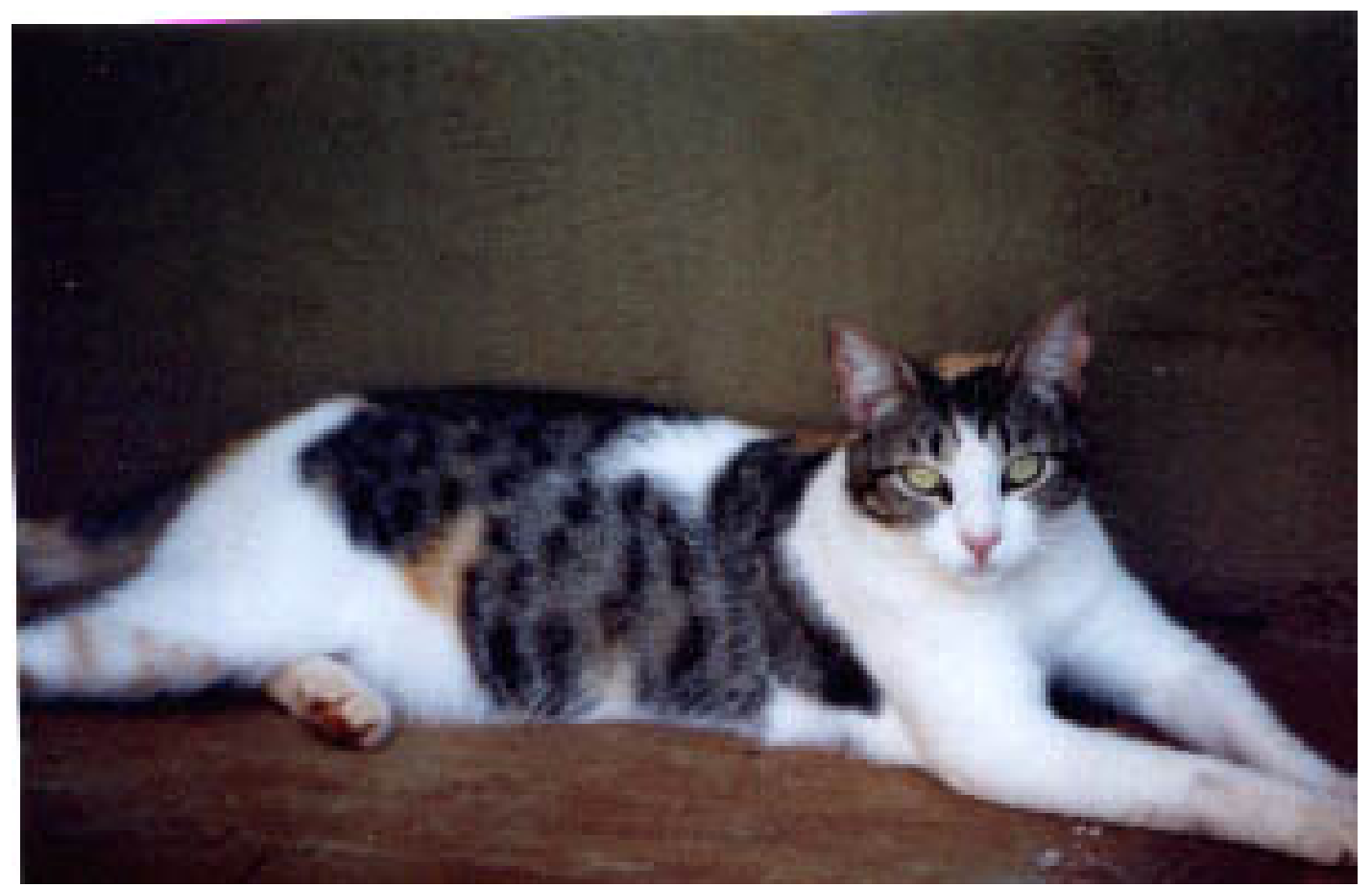

Foto 1 - Fêmea 11 (Animal 2.8 - Lú)

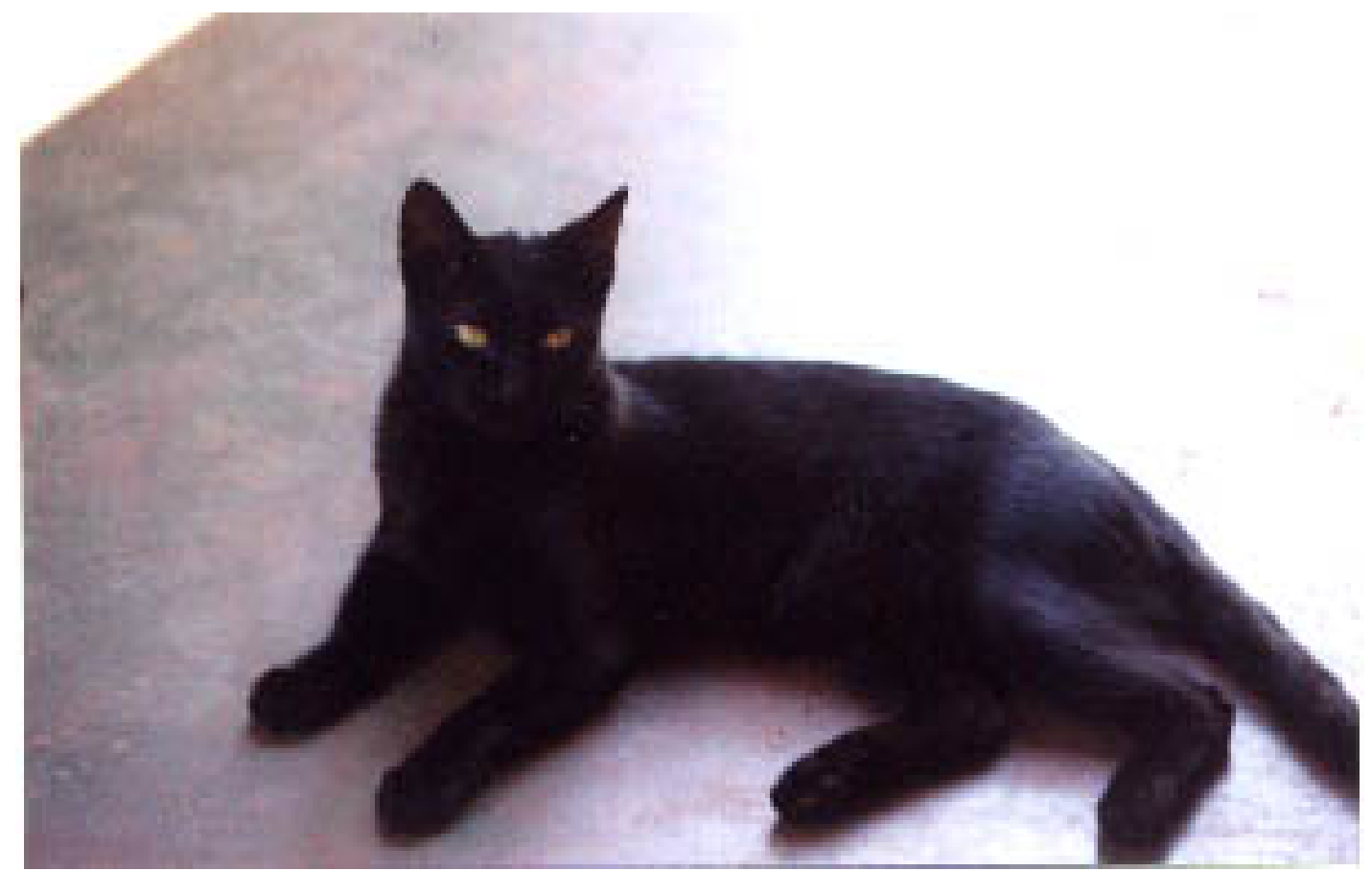

Foto 2 - Macho 4 (Animal 3.2) 


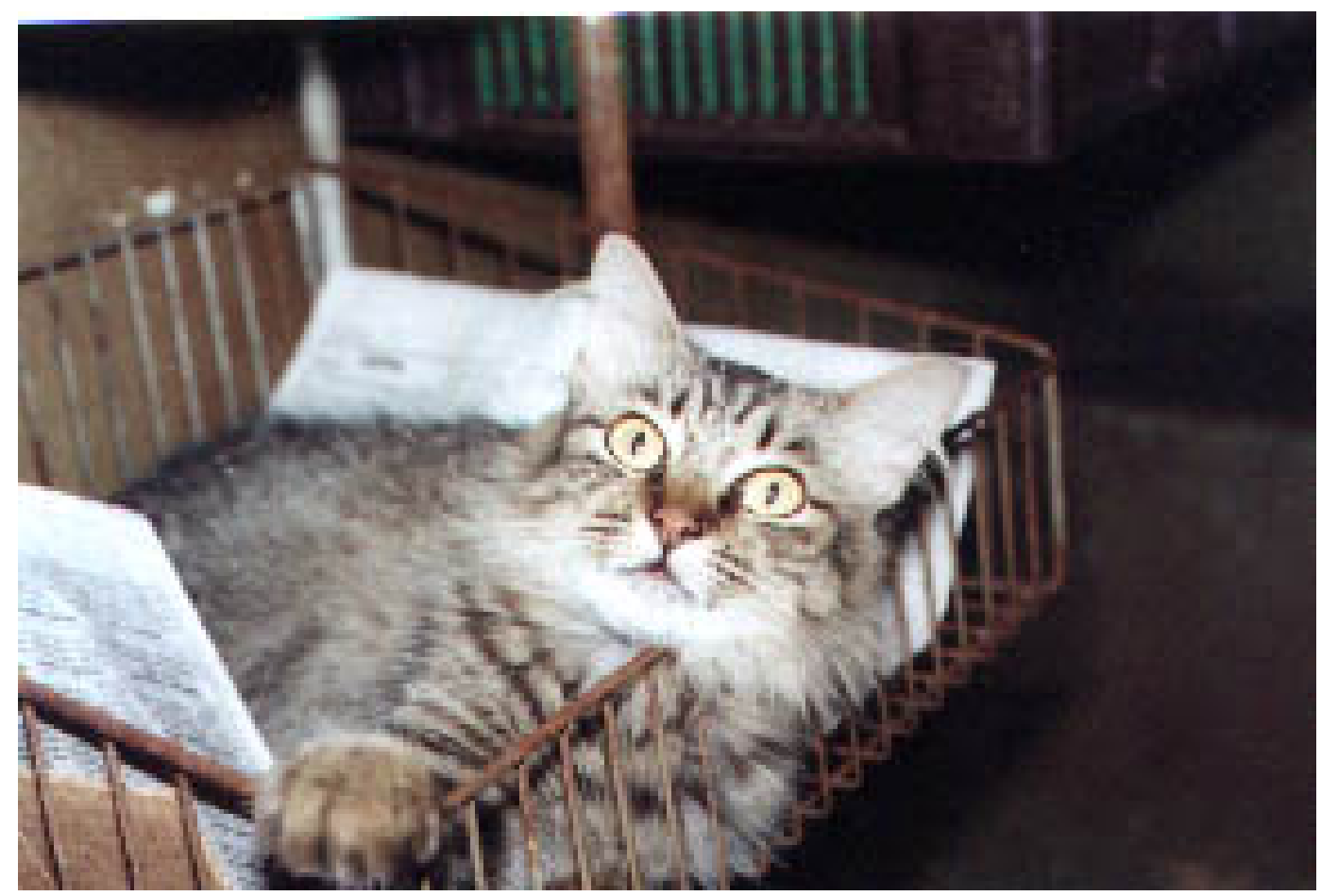

Foto 3 - Fêmea 22 (Animal 6.3 - Michele).

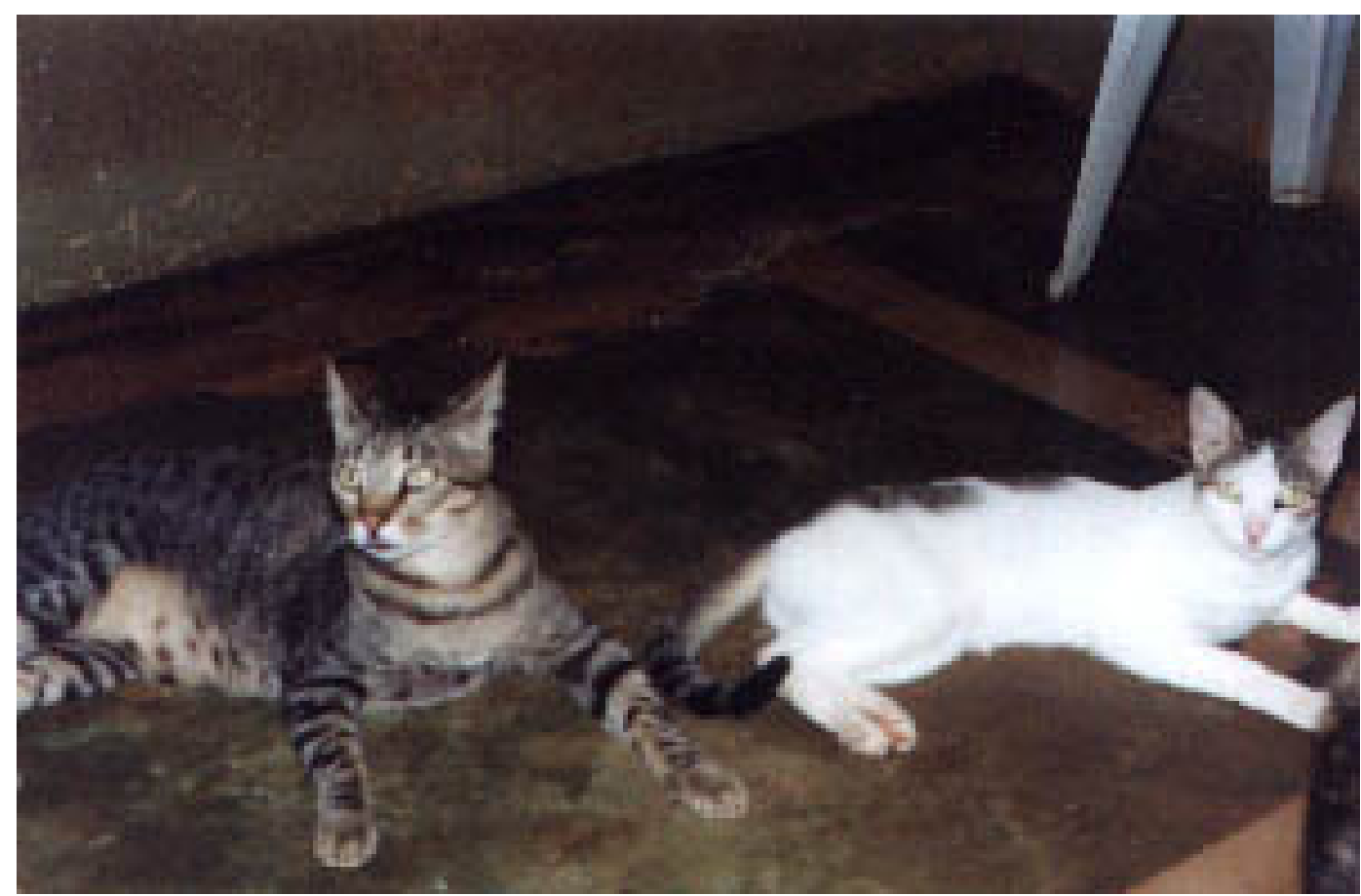

Foto 4 - Animal rajado cinza: (Macho 14 - Animal 6.1 - Quadrado), Animal branco: (Fêmea 3 - Animal 1.8). 


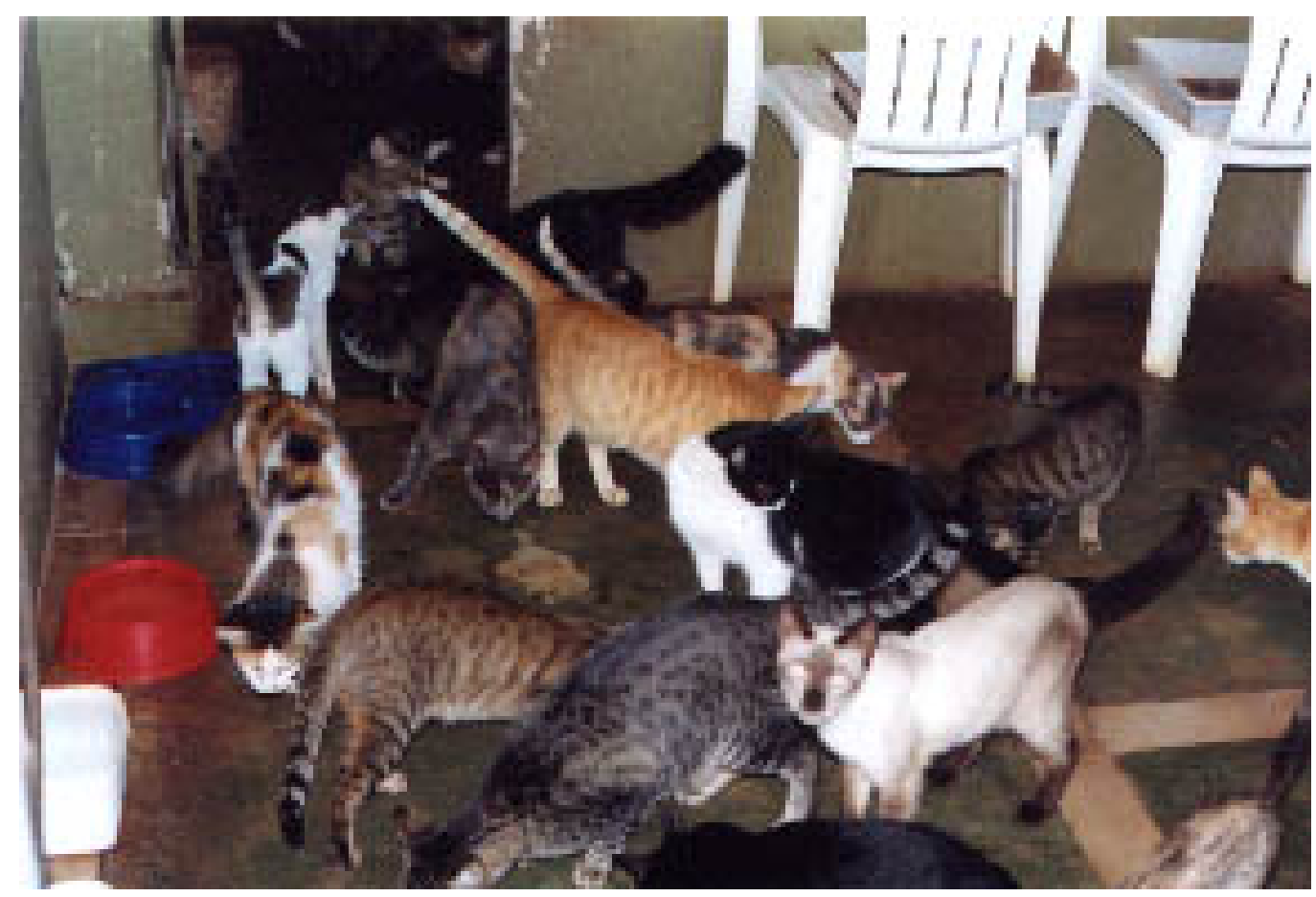

Foto 5 - Animais no solo no interior do Gatil esquerdo.

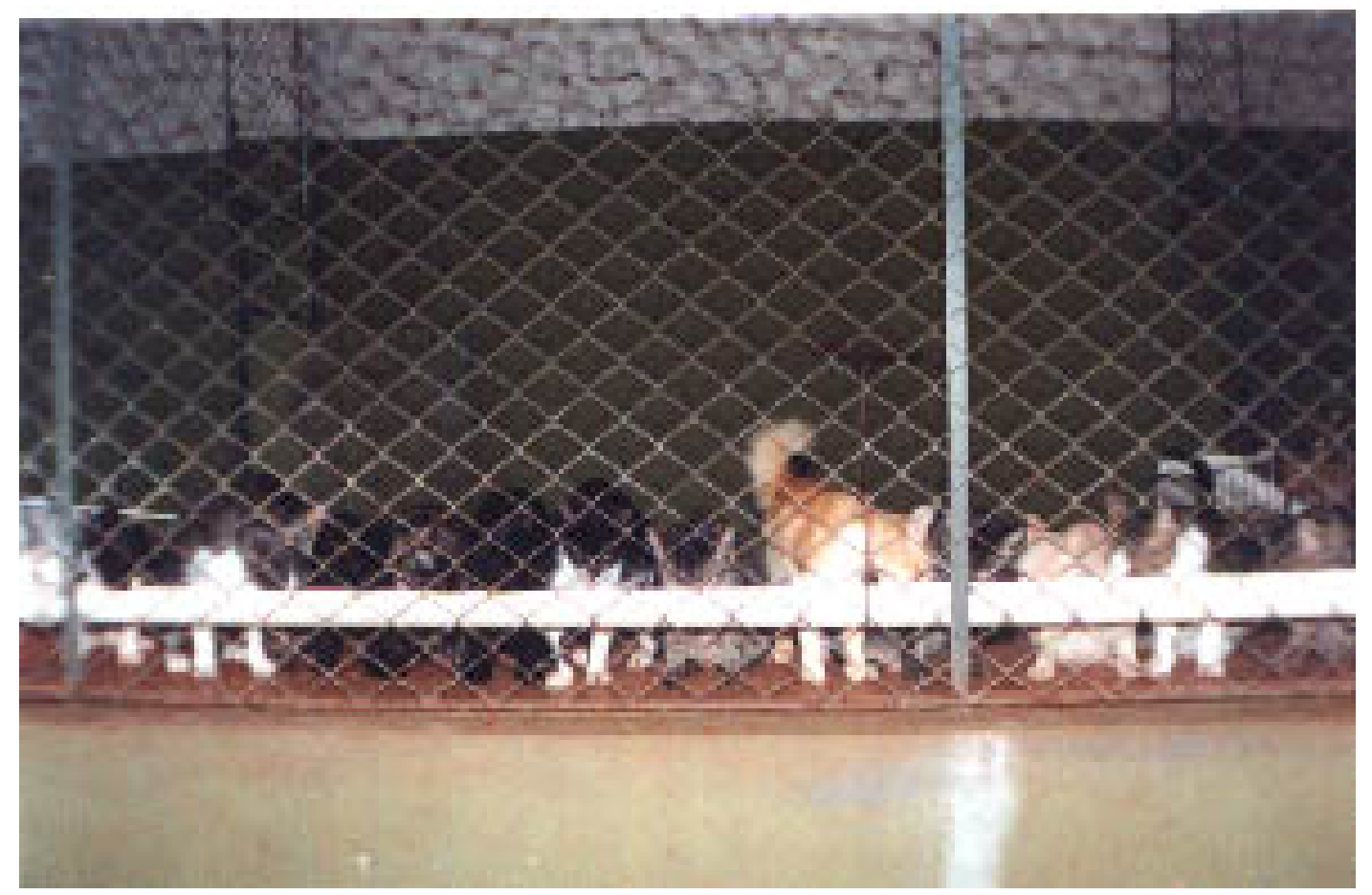

Foto 6 - Animais se alimentando no comedouro. Vista frontal do gatil. 